
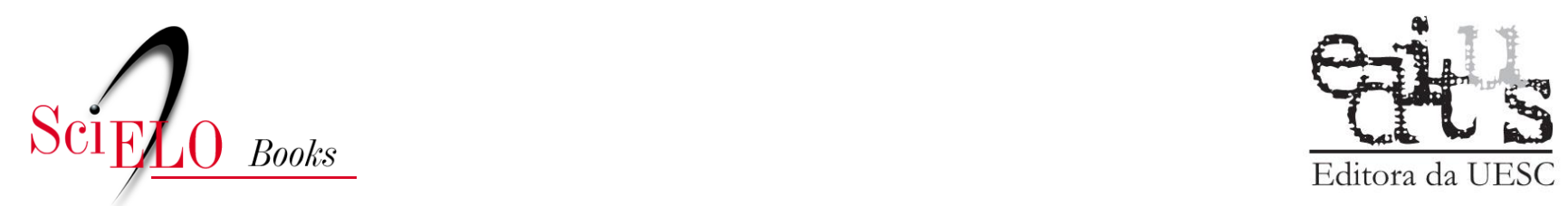

\title{
Literatura, homoerotismo e expressões homoculturais
}

\author{
André Luis Mitidieri \\ Flávio Pereira Camargo
}

MITIDIERI, AL., and CAMARGO, FP., orgs. Literatura, homoerotismo e expressões homoculturais [online]. Ilhéus, BA: Editus, 2015, 300 p. ISBN 978-85-7455-442-6. Available from SciELO Books $\langle$ http://books.scielo.org $>$.

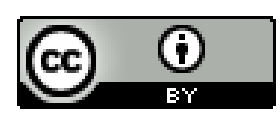

All the contents of this work, except where otherwise noted, is licensed under a Creative Commons Attribution 4.0 International license.

Todo o conteúdo deste trabalho, exceto quando houver ressalva, é publicado sob a licença Creative Commons Atribição 4.0.

Todo el contenido de esta obra, excepto donde se indique lo contrario, está bajo licencia de la licencia Creative Commons Reconocimento 4.0. 
Literatura, homoerotismo e expressões homoculturais 


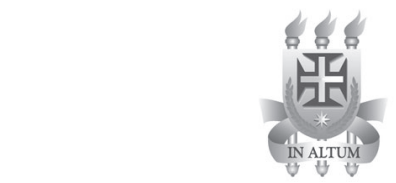

\title{
Universidade Estadual de Santa Cruz
}

\author{
GOVERNO DO ESTADO DA BAHIA \\ Rui Costa - Governador \\ SECRETARIA DE EDUCAÇÃO \\ Osvaldo Barreto Filho - Secretário \\ UNIVERSIDADE ESTADUAL DE SANTA CRUZ \\ Adélia Maria Carvalho de Melo Pinheiro - Reitora \\ Evandro Sena Freire - Vice-Reitor

\section{DIRETORA DA EDITUS} \\ Rita Virginia Alves Santos Argollo \\ Conselho Editorial: \\ Rita Virginia Alves Santos Argollo - Presidente \\ Andréa de Azevedo Morégula \\ André Luiz Rosa Ribeiro \\ Adriana dos Santos Reis Lemos \\ Dorival de Freitas \\ Evandro Sena Freire \\ Francisco Mendes Costa \\ José Montival Alencar Júnior \\ Lurdes Bertol Rocha \\ Maria Laura de Oliveira Gomes \\ Marileide dos Santos de Oliveira \\ Raimunda Alves Moreira de Assis \\ Roseanne Montargil Rocha \\ Silvia Maria Santos Carvalho
}




\section{André Luis Mitidieri | Flávio Pereira Camargo Organizadores}

Literatura, homoerotismo e expressões homoculturais

Ilhéus - Bahia

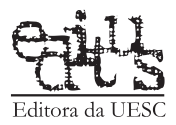

2015 
Copyright (C)2015 by André Luis Mitidieri | Flávio Pereira Camargo

Direitos desta edição reservados à

EDITUS - EDITORA DA UESC

A reprodução não autorizada desta publicação, por qualquer meio, seja total ou parcial, constitui violação da Lei n ${ }^{\circ}$ 9.610/98.

Depósito legal na Biblioteca Nacional,

conforme Lei n ${ }^{0}$ 10.994, de 14 de dezembro de 2004.

PROJETO GRÁFICO E CAPA

Álvaro Coelho

REVISÃO

Genebaldo Pinto Ribeiro

Roberto Santos de Carvalho

Silvia Maria Campos Teixeira

ILUSTRAÇÕES CAPA

São Sebastião, por Carlo Saraceni (c1610-15)

Dados Internacionais de Catalogação na Publicação (CIP)

L776 Literatura, homoerotismo e expressões homoculturais / André Luis Mitidieri, Flávio Pereira Camargo, organizadores. - Ilhéus, BA: Editus, 2015.

$301 \mathrm{p}$

Inclui referências.

ISBN 978-85-7455-379-5

1. Literatura homoerótica - História e crítica. 2. Homossexualismo na literatura. 3. Estudos sobre homossexualismo. I. Mitidieri, André Luis II. Camargo, Flávio Pereira.

CDD 809.933538

\section{EDITUS - EDITORA DA UESC}

Universidade Estadual de Santa Cruz

Rodovia Jorge Amado, km 16 - 45662-900 - Ilhéus, Bahia, Brasil

Tel.: (73) 3680-5028

www.uesc.br/editora

editus@uesc.br

EDITORA FILIADA À

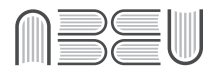

Associação Brasileira

das Editoras Universitárias 
Prefácio $>$ 


\section{DOS ARTEFATOS CULTURAIS QUE COMPÕEM A ORGANIZAÇÃO LITERATURA, HOMOEROTISMO E EXPRESSÕES HOMOCULTURAIS}

As expressivas manifestações culturais do homoerotismo têm encontrado respaldo em pessoas interessadas em desvelar para um público leitor aspectos, até então, não visibilizados dessas manifestações. Assim, paulatinamente, em contexto de Brasil, vimos ascender as questões homoeróticas, homoafetivas, queer, transitando entre as antigas bases de gênero (mas ainda tão produtivas, do ponto de vista teórico-metodológico, quanto os estudos mais centrados na visão do sujeito de hoje) e os novos modos de interpretação de sujeitos culturais.

Não é fácil em uma cultura ainda machista e homofóbica como a brasileira falar de questões da homocultura, porque, para muitos, elas ainda envolvem medo (de pessoas que sofrem ao querer se projetar fora do armário, e também por se manter dentro dele), moral (baseada em pressupostos religiosos, sobretudo os de base cristã), vergonha (como se o abjeto ainda e só tivesse interpretação na condição primeira, a menor, inferior), desinteresse (como se levantar a discussão em torno da homocultura fosse algo "desimportante"). 
Trazer à tona um universo homoerótico ambientando na literatura, na composição musical, nas discussões teóricas, sobretudo naquelas que apontam para universos de ficção científica, torna-se uma atividade que dá ao tempo de hoje outra perspectiva de interpretação dos sujeitos, das culturas em suas manifestações sobre a diversidade, a pluralidade, a liberdade de que se revestem os discursos de pessoas, personagens e seus contextos culturais, orientados, todos, para os caminhos culturais que se abrem às performatividades (no dizer de Judith Butler), às multitudes queer (como apontou Beatriz Preciado), à revisão semântico-cultural do sujeito lesbiano que não é "mulher" (na visão de Monique Wittig) e, por extensão, do sujeito homoerótico que não é homem, tendo-se em vista que nenhum dos dois participa das regras da economia straight.

Neste sentido, a organização de Flávio Camargo e André Mitidieri, Literatura, homoerotismo e expressões homoculturais, carrega em si o peso de uma aprofundada discussão, em seus vários ensaios, sobre essas expressões da homocultura, sobretudo daquelas fundadas sobre a literatura de ficção. Não é à toa que os articulistas ou ensaístas transitam por autores, teóricos e compositores, estes verdadeiros poetas da música (brasileira e inglesa), a exemplo de Renato Russo (da Banda Legião Urbana) e Morrissey (da Banda The Smiths).

Por outro lado, no campo estritamente literário, percebe-se que autores vão sendo exibidos, desvelados e mostrados ao público 
em uma visada que renova o campo semântico sobre as expressões homoculturais e seus sujeitos, injetando no campo discursivo visões mais livres de amarras teóricas e mais propensas à reflexão de sujeitos em seus contextos socioculturais. Passa-se, por exemplo, de Adolfo Caminha com Bom-Crioulo a Állex Leilla. No intervalo entre um e outra, autores como Valdo Motta, Tulio Carella, Lima Trindade, João Silvério Trevisan, Tomas Eloy Martinez, Gasparino Damata e Rubem Alves são entrelaçados na rede discursiva desta organização, priorizando-se o debate franco, acadêmico e pertinente às atuais questões em torno da homocultura.

Para além dessa tomada de escritas literárias, ainda há o diálogo, na mesma organização, com outra produção escrita geralmente considerada menor, a literatura de cordel, demonstrando que as expressões culturais, antes de se tornarem objeto de estudo, são construídas em vários contextos e por vários sujeitos, mantendo-se a pluralidade como princípio. Por fim, questões em torno de lesdroides, transborgues e interaliens surgem como possibilidades interpretativas deste universo que, ao tempo em que procuram superar a lógica dos modelos de gênero e sexualidades, evocam formas de existências capazes de ir além do dado. A fembot torna-se, assim, uma referência imagético-discursiva para ampliar as discussões sobre sujeitos e seus lugares nas culturas.

Diante desse arsenal de autores e pontos de vista teóricos sobre sujeitos culturais, 
torna-se evidente a homocultura: definindo-se em vários contornos teóricos, assenhoreandose de lugares antes não possiveis, adentrando o campo discursivo sem pressão e sem o aspecto militante, provando-se que espontaneamente a necessidade de discutir a homocultura em suas várias expressões e de lançar para leitores as visadas que se tem sobre sujeitos e produtos da homocultura é um exercício proficuo, resultando, de certa forma, em uma politica (propaganda) afirmativa.

Prof. Dr. Antonio de Pádua Dias da Silva

Programa de Pós-Graduação em Literatura e Interculturalidade - Universidade Estadual da Paraíba 
Dai-me de beber que tenho uma sede sem fim: notas sobre 0 jeito de corpo, de Morrissey e Renato Russo Alessandra Leila Borges Gomes (Állex Leilla)

\section{1}

Biografemas homoculturais de Eva Perón no romance Santa Evita, de Tomás Eloy Martínez André Luis Mitidieri

\section{7}

Dialogismo entre textos bíblicos e poemas de Valdo Motta na construção do tema homoerótico

Carlos Eduardo Albuquerque Fernandes

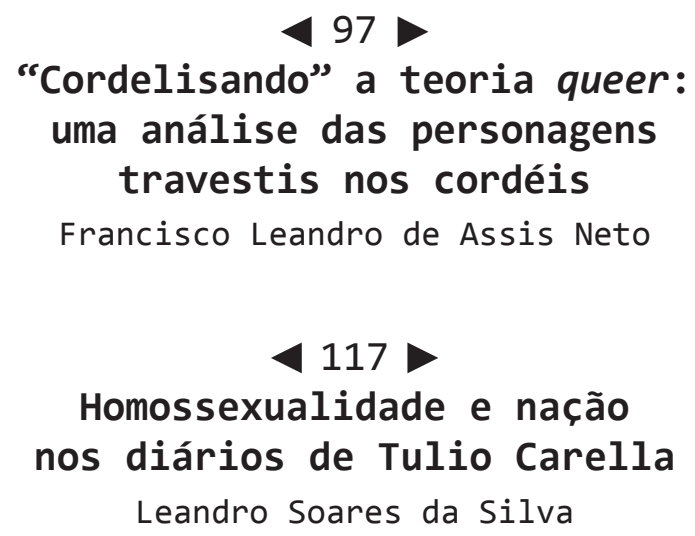


Lesdroides, transborgues, interaliens: personagens científico-ficcionais além das fembots

Luana Barossi

\section{5}

"Eu amo Abel como a mim mesmo e o amor de Jesus é o mesmo dentro de nós": a dessacralização do divino na obra Em nome do desejo, de João Silvério Trevisan Maria de Fátima Lopes Vieira Falcão; Flávio Pereira Camargo

\section{1}

Os solteirões: dentro ou fora do armário? Micaela Sá da Silveira; Antonio de Pádua Dias da Silva

4217

Imagens do homoerotismo

na ficção baiana

Paulo César Souza García

4241

A força do desejo homoerótico interseccionado com questões de raça em Bom Crioulo, de Adolfo Caminha Rubenilson Pereira de Araujo

\section{5}

Representação discursiva da diversidade sexual em $O$ gato que gostava de cenouras, de Rubem Alves Vanessa Rita de Jesus Cruz; Flávio Pereira Camargo 
Literatura, homoerotismo e expressões homoculturais 


\section{DAI-ME DE BEBER QUE TENHO UMA SEDE SEM FIM: NOTAS SOBRE $O$ JEITO DE CORPO, DE MORRISSEY E RENATO RUSSO}

Alessandra Leila Borges Gomes (Állex Leilla) ${ }^{1}$

Este trabalho é fruto de um estudo comparativo entre as performances apresentadas pelo cantor inglês Morrissey (1959) e o músico brasileiro Renato Russo (1960-1996). Com o objetivo de ler suas performances no palco e a relação delas com o conteúdo das letras, estabeleço diálogos que ora os aproximam, ora os afastam. Parto do princípio de que a ambiguidade lírica presente nas letras de Morrissey, bem como os elementos escolhidos para sua performance smithiana e, sobretudo, sua tendência à incorporação de um modelo melancólico de canto e escrita, formaram uma atmosfera propícia que estimulou o desempenho de Renato Russo nos palcos tupiniquins. Proponho a ligação entre ambos, não apenas porque sou, confessadamente, admiradora dos dois, mas também porque este recorte faz parte de uma pesquisa maior, em que tento compreender a abordagem

1 Doutora em Estudos Literários pela UFMG; é professora adjunta de Literatura Portuguesa, da Universidade Estadual de Feira de Santana (UFES), onde atua também no Programa de Pós-Graduação em Estudos Literários.

E-mail: <allexleilla@gmail.com>. 
singular e produtiva que alguns escritores e artistas fazem acerca do amor e de suas vivências sexuais.

Além do tom homoerótico das letras de Morrissey e Renato Russo, sempre me chamaram atenção o investimento deles na ideia de outsider, bem como o cultivo da melancolia enquanto justificativa da criação e/ou criatividade. Para esta leitura, tomo o conceito de dispositivo histórico-cultural de Michel Foucault, e o de montagem, de Canclini, e dialogo, também, com a ideia da singularização do desejo que, segundo Shirley Talburt, advém de uma consciência de que a sexualidade não habita um campo previamente construído, mas apresenta significados relacionais que se constroem, se imitam e são imitados.

Interessa-me compreender a ideia do artista ou criador marginal, ora denominado de outsider, para além das relações mercadológicas ou socioculturais mais comuns ao termo; mais especificamente, interessa-me a noção advinda de uma vontade do sujeito de não apenas produzir de forma subversiva, mas de se posicionar subversivamente frente a um poder estabelecido - mainstream, establishment, established. A pressuposição dessa ordem vigente a que se deve contrariar é que determinam os processos de desconstrução e deslocamento das leis (expressas formalmente ou internalizadas, via ideologia dominante) dos estatutos, técnicas de produção, hábitos, linguagens, linhagens. Trata-se de uma condição de borda, que, no entanto, ambiciona chacoalhar o centro, pois parte do 
pressuposto de que a vida nele é definida por um formato repressor e restritivo.

Ser outsider é rejeitar as estruturas culturais oficiais estabelecidas; é buscar formas alternativas de circulação para sua criação. Baudelaire, Lautréamont, Rimbaud, Burroughs, os poetas beats, entre outros, são nomes que surgem ao se pensar numa poesia de borda, de deriva, no mundo ocidental. No entanto, nesse termo ainda cabe muito mais se levarmos em conta que toda a busca de uma musicalidade transgressora, de uma valorização de imagens incomuns, de uma tentativa de tornar o intimo falado, exposto e, paradoxalmente, isolador. Nos dois artistas escolhidos, está diretamente ligada à perda de fronteiras entre os gêneros, entre as representações artísticas e o seu conceito de "real" - o que remete as figuras de Morrissey e Renato Russo tanto para uma estirpe de artistas marginais, que deseja articular a noção de sociedade e indivíduo com a ideia da criação transgressora, escandalizando, dialogando e suplementando a vida, quanto para a percepção de artistas consagrados e bem-sucedidos que, inclusive, já contam, há décadas, com seguidores.

Para um consumidor de rock inglês, o termo outsider não soará estranho ou inadequado, uma vez que o início da carreira de Morrissey, como letrista e vocalista da banda The Smiths, foi marcado pela escolha de uma gravadora independente (Rough Trade), pela recusa em fazer videoclipes (peça promocional considerada imprescindivel nos anos 1980) ou de participar 
de programas de TV, conhecidos no cenário pop, por seu poder massificador. Mas a palavra outsider pode provocar interrogação diante da presença, hoje, de um Morrissey cada vez mais lendário, que não cansa de declarar nas entrevistas estar há dez anos sem gravadora, mas, ao mesmo tempo, ser capaz de esgotar em menos de uma semana os ingressos de seus shows - como ocorreu em 2012 nos EUA, e também no Rio de Janeiro (Fundição Progresso) e São Paulo (Espaço das Américas), na turnê realizada pelo músico no Brasil. Mais interrogações, decerto, surgiriam com o uso do termo outsider para Renato Russo, cujos shows contavam, em média, com um público de quarenta mil pessoas, e cuja banda, a Legião Urbana, não só foi um fenômeno de vendas na década de 1980, como segue vendendo muito até hoje, dezessete anos após a morte de seu líder.

Todavia, quero pensar a ideia de outsider, a partir da linha oferecida por Colin Wilson, em Outsider: o drama moderno da alienação e da criação (1985). Esse livro problematiza a sensação de marginalidade manifestada pelos escritores e artistas românticos, sob o manto ou culto do estado melancólico. Para ele, o criador outsider é uma espécie de indivíduo que prediz o futuro, mas não tem total consciência desse poder mental; ou seja, é um profeta ainda inconsciente de seu papel e poder. Sua inadequação e sofrimento transbordam, pois ele precisa salvar-se através do encontro (revelação) com essa "missão"; no entanto, ele só sabe de maneira indireta ou parcial sobre 
seu destino, e, ao mesmo tempo, intui sobre ele e dele necessita para realizar o seu projeto de epígono - que é seu verdadeiro objetivo na terra. Abraçar uma manifestação artística é parte desse caminho, porém, não é o caminho, e sim um meio para sua realização de profeta. Wilson mostra que a inadequação dos outsiders é um princípio básico de sua condição, mas diferentemente de uma inadequação oriunda de uma dificuldade de acesso sociopolítico cultural, ou, ainda, advinda de uma consciência crítica ao meio, ela surge, antes, de uma espécie de dor, compreendida como inerente ao pária. Constantemente, um sentimento de irrealidade acerca de si mesmo e do mundo ao seu redor os acompanha. Sua existência é marcada pela experiência de momentos de interiorização profunda, donde emergiria o desejo de mudar o mundo. Esse desejo pode levar ao desenvolvimento de uma imaginação fértil, dada a visões de planos superiores que, por não serem facilmente alcançados, resultam em tristeza e imobilidade. Suas crenças místicas são flutuantes e a concepção de sociabilidade confunde-se com o pavor e o desprezo pelos condicionamentos sociais. Produzir seria uma forma de acessar esse mundo interno: dai-me de beber que tenho uma sede sem fim é o mantra que leva o outsider ao prazer de criar ou à epifania ocasionalmente sentida no ato de criação, mas, por ser um processo circular e sem chances de plenitude ou satisfação, criar não o impede de cometer certos desastres com a própria 
existência - suicidarem-se, por exemplo, ou abandonarem a arte devido a um profundo desgosto com seus frutos -, afinal, um dos componentes dessa indole outsider é sua tendência ao tormento, às sombras, às ruínas, à autodestruição.

Escolho pensar sobre as letras, depoimentos e performances de Morrissey e Renato Russo, a partir da percepção dessa necessidade forte, que ambos apresentam, de resolver os impasses existentes entre a tendência outsider (que os leva ao isolamento) e a utopia mística de celebração e reunião de tribos da música rock (que os leva à sociabilização). Tanto o projeto estético de Renato Russo quanto o de Morrissey estão diretamente ligados às relações orgânicas entre os movimentos juvenis e o estilo de música a que denominamos rock. As desilusões do cenário do pós-guerra fundam essas práticas histórico-discursivas da cultura rock e, até hoje, na contemporaneidade, tal dispositivo pode funcionar como catalisador dos anseios, do vigor juvenil e da rebeldia adolescente, determinando e/ou viabilizando o tipo de relação que seu público, produtor e consumidor, terá com os organismos sociais - a familia, a escola, a religião, o governo, o mercado de trabalho etc. Ao passar assim de gênero musical a dispositivo histórico-cultural, a música rock inventa e desinventa identidades, aglutinando valores dispersos pela sucessão de épocas, gerações e manifestações juvenis urbanas. No espaço dessa cultura, porém, paira sempre a ideia de uma 
atitude contestatória, uma postura de eterna desconfiança daquilo que fala por vias oficiais, além de uma forte necessidade de afirmação pessoal.

No entanto, qualquer análise que tenha essa manifestação artística em seu horizonte de discussão não poderá prescindir de seu papel não apenas no funcionamento econômico e social da maioria dos países ocidentais, mas, sobretudo, na ampliação cultural que se faz cada vez mais descentralizada, fragmentária e múltipla nos grandes centros urbanos. Tal ampliação pode ser mais bem pensada a partir das considerações de Nestor García Canclini, em Consumidores e cidadãos (2001); ele elabora o conceito de montagem, para ler a especificidade da fragmentação que os objetos culturais adquirem quando retirados de seu lugar de origem e fabricados noutro: "A cultura é um processo de montagem multinacional, uma articulação flexível de partes, uma colagem de traços que qualquer cidadão de qualquer país, religião e ideologia pode ler e utilizar" (2001, p. 41).

A noção de cultura como uma montagem permite pensar não apenas no fim da "unidade imaginada", representada pelas narrativas universais, mas, sobretudo, numa ação ativa dos sujeitos envolvidos na fabricação, mediação e circulação de valores e artefatos culturais. Esse operador faz desaparecer qualquer resíduo ou preocupação com a demarcação de manifestações artísticas genuinamente brasileiras, por exemplo - o que é produtivo se levarmos 
em conta que esse tipo de limite foi muito usado para desvalorizar a música produzida pelas bandas de rock nacional, no início da década de 1980. As subjetividades, então, passam a ser vistas dentro de uma operação dinâmica de reunião, seleção e deslocamento de dispositivos, peças e mecanismos complexos que fazem funcionar a cultura. Montagem implica cortar, selecionar, colar, formar novas imagens e narrativas, e, na cultura, o que chama a atenção, desde algum tempo, são os produtos híbridos, que podem conter tanto experiências, estratégias, valores e gêneros da tradição artístico-literária ocidental, quanto elementos da indústria do entretenimento, da cultura oriental e de outros discursos tantos. Nesse cenário, a música rock desponta como um espaço de intercambiamento entre discursos, tendências e valores da tradição (literatura, arte, filosofia, religião) com as designadas "realidades secundárias": ícones da cultura de massa, clichês midiáticos, marcas publicitárias, tecnologias, produções cinematográficas, histórias em quadrinhos etc.

O rock, de modo geral, fez valer a máxima de que "tudo lá fora" passa, antes, pelo indivíduo. O valor individual a ser cultivado é sempre o da criatividade, que, por sua vez, se inscreve no corpo e na cena, numa performance capaz de abranger o sensorial e o político, tornando-se não apenas uma característica tribal, mas uma carnadura urbana. A própria "natureza" do estilo musical a que convencionamos chamar de música rock é, na verdade, uma hibridização de estilos, pois, desde sua 
origem, entre 1954-55, já abarcava vários ritmos da música negra norte-americana, como o blues, o gospel, o country e a canção popular, entre outros. Uma definição possivel da especificidade da música rock foi dada por Antônio Souza, em Cultura rock e arte de massa $a^{2}$.

A cultura rock seria tanto uma modulação do ouvido, que estaria aberto a diversas sonoridades da nova música comercial, como um modo de vestir a camisa, uma maneira relaxada de jogar o corpo na rua, de passear no meio da multidão, ainda que tenha à mão uma pasta carregada de promissórias para pagar no banco, no caso dos jovens roqueiros trabalhadores. Evidente que todas essas pequenas manifestações são sinais do sistema cultural que o rock vem construindo ao longo destes anos. [...] Uma mobilização a princípio musical, que deixa marcas nas representações, na percepção e no entendimento que o jovem tem de si próprio e do funcionamento do próprio mundo. [...] um sistema que inicia o adolescente na sociedade e pode desde modular suas pequenas atitudes até orientar sua compreensão e postura política no mundo (1995, p. 28-29).

A palavra "modulação", enfatizada na definição acima, é fundamental para se compreender a estrutura do rock, pois o mecanismo

2 Tese de doutorado defendida em 1994, na Faculdade de Filosofia de Campinas, e publicada em 1995, pela Editora Diadorim (Cf. referências). 
de modulação está presente tanto na captura material da música (modulação do ouvido) quanto na organização dela no cotidiano de seu consumidor (modulação de atitudes). A preferência em usar "modular" e não "modelizar" mostra um cuidado do autor para não cair no jogo improdutivo das teorias que postulam uma massificação do rock, operada pela indústria do entretenimento (perceptível, justamente, na estereotipação mundial de seu público), e, sobretudo, implica não deixar escapar um elemento importante no universo cultural da música rock: sua busca por um lugar de singularidade, de liberdade individual, quer para o artista, quer para o público.

Já foi por demais dito que, no interior da cultura rock, há também divisões e subdivisões que hierarquizam bandas, artistas, estilos, subgêneros e épocas, numa reprodução clonada do jogo de forças que existe entre alta e baixa cultura. O universo heterogêneo da música rock pode criar armadilhas para diferenciar subestilos e tendências, multiplicando ao infinito o caráter gregário e tribal do próprio gênero musical, conforme explica Lawrence Grossberg, em Dancing in Spite of myself: Essays on Popular Culture: "Rock and roll não é caracterizado somente pela heterogeneidade musical e estilística: seus fãs diferem radicalmente entre si apesar de ouvirem o mesmo tipo de música" (GROSSBERG, 1997, p. 29).

Todavia, mesmo com essas nuances que formam vertentes e subgêneros - e com eles fronteiras, ainda que tênues, entre um público 
e outro, uma banda e outra -, a cultura rock compreende a formação de práticas sociais e estéticas que possibilitaram e ainda possibilitam identidades, objetos artísticos e comportamentos cuja dimensão ultrapassa os seus limites sonoros, pois se inscrevem numa zona mais ampla de dispositivos histórico-politicosociais das culturas urbanas juvenis.

Stephen Patrick Morrissey nasceu em 1959, na cidade de Manchester, na região norte da Inglaterra, e descende de uma família de origens irlandesas. Segundo o biógrafo Johnny Rogan, em Morrissey \& Marr: The Severed Alliance (1992), ele cresceu num ambiente de muita repressão católica e escassas provas de afeto, por isso, teve uma adolescência solitária, alicerçada por leituras de escritores clássicos e de revistas pops, além de saidas pontuais para assistir a shows de rock de idolos como Rolling Stones, David Bowie, The Clash e New York Dolls. Essas referências biográficas são exploradas pelo letrista à exaustão e compõem toda uma mitologia em torno de uma ausência de relacionamentos amorosos em sua vida, um isolamento do mundo e até uma opção pela abstinência sexual, destacada por ele em quase todas as entrevistas, quando aproveita para jogar com a persona construída, estabelecendo um limite claro entre sua carreira e sua intimidade, rigorosamente preservada. O cantor despontou no cenário pop britânico em 1983, com a banda The Smiths, formada a partir de uma parceria com o guitarrista Johnny Marr. Com 
os The Smiths, lançou cinco discos e mais uma infinidade de antologias e singles. Após a dissolução da banda, continuou em carreira solo, contabilizando, hoje, cerca de doze trabalhos, mais dois boxes com singles, vários DVDs e três discos ao vivo. Morrissey é formado em carpintaria, uma espécie de curso técnico, e antes de fazer sucesso trabalhou como porteiro de hospital. É leitor de Keats, Yeats, Oscar Wilde, Shelagh Delaney e Fernando Pessoa, entre outros.

A singularidade de sua performance no palco é interessantíssima, porque permeada de elementos dispares e incomuns à cena pop da época. Em meio a momentos de sensualidade explícita, podemos, por exemplo, flagrá -1o, no palco, usando óculos ou aparelho de audição, cujos modelos grosseiros eram distribuídos gratuitamente pelo serviço de saúde britânica. O Morrissey smithiano concentra-se numa ideia ambigua de sexualidade: enquanto as letras alternam a vivência do desejo heterossexual ("Half a Person", "I know its over", "Girlfriend in a Coma") com o homoerótico ("Hand Glove", "Handome Devil", "This Charming Man"), o vocalista se cerca de elementos plurívocos para adornar sua dança no palco, como flores nos bolsos detrás das calças jeans, camisas de mangas compridas deixando entrever a nudez pálida dos ombros, muitos colares no pescoço, um topete que ora invoca James Dean, ora Elvis Presley, e o investimento em ícones cinematográficos e literários, como pano de fundo para as apresentações. 
Os ícones escolhidos, em geral, repetiam as imagens das capas dos discos da banda, que exibiam ora garotas em poses de intelectuais, ora torsos nus de rapazes, ou cenas de filmes e séries de TV. As imagens estão ligadas a uma cultura underground (a exemplo das referências explícitas à escritora inglesa Shelagh Delaney, autora de Um gosto de mel, ao cineasta Paul Morrissey, cuja circulação estava restrita a certo nicho cultural, ao nu provocante do astro pornô Leo Ford ou ao transexual Candy Darling, dos filmes de Andy Wharol) ou simplesmente são registros de famosos que eram admirados pela banda (Alain Delon, Richard Davalos, Pat Phoenix, Truman Capote, Diane Dors etc.).

A dança morrisseriana no período smithiano é conhecida pela mistura de desajeito e sensualidade, seus movimentos nos shows mostravam certa feminilidade no jeito de mexer os quadris e uma postura rebelde e celebrativa da atmosfera tribal de seu público, composto, na época dos The Smiths, por uma plateia predominantemente masculina, que invadia o palco para abraçar, oferecer flores e dançar junto com o vocalista. Nesse período, os gestos de Morrissey incorporam os trejeitos doces da cantora pop britânica Sandie Shaw, os gritos rebeldes e o ato de rasgar a própria camisa, oriundos da banda punk norte-americana New York Dolls, e, ainda, o rebolado de Elvis Presley. A atmosfera melancólica presente nas letras de Morrissey funcionava como um contraponto 
para a guitarra festiva, dionisiaca de Johnny Marr (seu parceiro em todas as composições dos The Smiths) e sofreu uma modificação substancial em sua carreira solo - iniciada após o rompimento com a banda, em 1987 -, quando foi minimizada por uma ênfase maior numa performance mais viril, inspirada no Elvis Presley de "My Way", e numa sonoridade que, muitas vezes, retorna ao Rockabilly ${ }^{3}$, ou, muitas vezes, bebe no Bowie dos anos 1970, abandonando o universo conflituoso das experiências juvenis para um distanciamento mais crítico e conceitual das relações afetivas. Agora, Morrissey não leva mais flores nos bolsos, seu público é quem as leva e abarrota o palco jogando pétalas e presentes variados ao cantor que ora pega, ora joga de volta; as camisas não são mais rasgadas durante as danças, ele as tira e joga, duas ou três, para que o público as rasgue e leve para casa como souvenir. Hoje, Morrissey tanto pode nos mandar dançar numa determinada música, como mandar que nos comportemos, façamos silêncio durante o show; pode cumprimentar com apertos de mão quem está na

3 Designação tanto para o rock de raiz de Jerry Lee Lewis, Johnny Cash, Roy Orbison, Chuck Berry, Eddie Cochran, Buddy Holly e Gene Vincent, quanto os próprios ídolos do Rock and Roll. Atualmente, existem algumas bandas que tocam rockabilly e misturam elementos do punk (Cramps) ou do rock progressivo, ou mesmo da new wave (Morrissey). Sonoramente, o estilo é definido por batidas percussivas que ora se destacam das linhas das guitarras e dos contrabaixos acústicos, ora se fundem com a técnica slap-back (cordas batidas em vez de puxadas individualmente): REY, Leopoldo; PHILIPE. Gilles. Livro Negro do Rock. Rio de Janeiro: Ed.Somtrês, s/d. MUGGIATI, Roberto. História do Rock. Rio de Janeiro: Ed.Somtrês, s/d. 
frente do palco, quanto nos ameaçar, de repente, usando o fio do microfone como se fosse um chicote.

Suas letras continuam a trazer uma captura de experiências e visões de mundo em que não uma, mas diversas "juventudes" são percebidas, com seus conflitos comportamentais que, muitas vezes, resultam numa guerra entre os jovens e a cultura estabelecida. Contudo, diferentemente de RR, as letras de Morrissey optam pelo registro irônico e plurívoco dessa guerra. Nesse sentido, ele se beneficia da possibilidade de indefinição de gênero, facilitada pela estrutura da lingua inglesa, na qual é possivel se dirigir a um you que não precisa ser marcado pela terminação verbal, enquanto RR buscava na primeira pessoa do plural o indice de indeterminação quando queria jogar com a ambiguidade - o que era raro de acontecer.

A ambiguidade presente não apenas nas letras, mas na dança morrisseriana inspiraram Russo, que desde o início buscou uma sintonia com o universo smithiano, chegando a declarar em entrevistas que as duas bandas de que mais gostava no mundo eram Beatles e The Smiths. Renato Russo ${ }^{4}$ é o pseudônimo autoral de Renato Manfredini Júnior, um dos músicos, compositores, vocalistas e letristas que mais se destacaram no cenário da música e da cultura rock nas décadas de 1980 e

\footnotetext{
4 Renato Russo é uma hibridização aportuguesada de três autores - Jacques Rousseau, Henri Rousseau (o pintor) e Bertrand Russel (o filósofo), lidos pelo músico no período em que vivia em Brasília, na época que precedeu a formação de sua segunda banda, a Legião Urbana.
} 
1990, no Brasil. Sua produção artística liga-se às mudanças ocorridas nas artes e nos paradigmas da cena cultural da década de 1980, e à reformulação dos novos papéis ou mediações que ela adquire. Tais mudanças afetaram a definição de cultura, que cada vez mais foi perdendo a possibilidade de ser conceituada, a partir de fatores polarizantes e hierárquicos, com os quais um dia foi tratada. Russo faz parte de uma geração de músicos e letristas dos anos 1980 que se insere no cenário cultural brasileiro como a geração que se profissionalizou junto com a indústria musical nacional, a geração que usou a efervescência do punk britânico e do norte-americano para produzir e viabilizar suas criações. Com a Legião Urbana, ele lançou sete discos inéditos e um registro ao vivo. Como intérprete solo, ainda lançou dois álbuns, um em inglês - Stonewall in Concert (1994) - e outro em italiano - Equilíbrio distante (1995). Após sua morte, foram publicados diversos trabalhos, tanto com registros de shows, quanto com sobras de interpretações dos trabalhos em inglês e italiano, e até duetos (ocorridos de verdade ou "inventados" em estúdio), além de gravações caseiras e trechos de entrevistas.

Renato Russo vem de uma família de origem italiana, mas nasceu na Ilha do Governador (RJ), em 1960, década que começou com a eleição de Jânio Quadros e terminou com o Brasil mergulhado na ditadura militar. Seu pai era economista do Banco do Brasil e a mãe, professora. Sua família se estabeleceu 
em Brasília por volta de 1970, depois de ter vivido por dois anos nos Estados Unidos - onde o músico, dos 7 aos 9 anos, aprendeu a falar e a redigir em inglês. Era formado em jornalismo e, antes de fazer sucesso com a Legião Urbana, trabalhou num órgão público, em rádio, e deu aulas de inglês na Cultura Inglesa.

A singularização do sentimento de solidão, da perda da inocência, da crise de identidade e até as dificuldades de adaptação escolar, tematizadas por Morrissey, serão absorvidas pelas letras da Legião Urbana, em meio às questões relacionadas ao afeto, vida política e sexualidade. Entretanto, ao contrário da ambiguidade do letrista britânico, Russo opta pelo registro quase sempre na primeira pessoa, investindo numa ideia de sinceridade que, até hoje, provoca em seu público uma espécie de leitura direta entre o conteúdo das letras e a vida/verdade do cantor. A figura de Morrissey representou, para $R R$, durante algum tempo, não apenas a visibilidade de uma "sensibilidade gay", mas, sobretudo, a possibilidade de uma referência mais próxima de suas idiossincrasias, uma vez que, dentro da maneira temperamental de RR ver o mundo, a sensibilidade manifestada de um Bob Dylan, de um Mick Jagger, de um Jim Morrison, entre outros ícones que ele admirava, eram mais passiveis de ser pulverizadas pela espacialização da cultura rock, além de não contemplarem especificamente o tema da diversidade sexual, que tanto interessava ao roqueiro 
brasileiro ${ }^{5}$.. Morrissey trazia não apenas a questão sexual, ele a encenava a partir da imagem perfeita do outsider, melancólico e diferente, que criara um mundo à parte dentro do cenário do rock mundial. Quando Renato Russo descobriu, tempos depois, que essa performance morrisseriana era uma construção e não uma extensão natural de suas vivências, confessou estar decepcionado, pois havia descoberto, entre outras coisas, que Morrissey era um exímio nadador e jogava basquete ${ }^{6}$ e, portanto, não podia ser um cara que sofria de depressão.

A performance de Renato Russo foi montada a partir de elementos morrisserianos, e, também, da incorporação do gestual de Jim Morrison (1943-1971, The Doors) e Ian Curtis (1956-1980, Joy Division), entre outros. A dança híbrida do vocalista, que, muitas vezes, nos fazia pensar que ele estava tendo um ataque epilético no palco, era uma catarse que suplementava suas músicas e letras, numa celebração da atmosfera de aldeia da música rock; reafirmava a festa dos modelos de vida alternativos; positivava o corpo; gritava um "não" aos recalques e às demais formas de repressão; retomava Narciso e Orfeu, e mais Dionísio, com quem desejava ritualizar essa

5 Para melhor compreensão da especificidade de tais ideias, ver a entrevista de Renato Russo concedida a José Augusto Lemos, à revista Bizz, em 1987 (quando o artista se assumiu publicamente homossexual) ou, ainda, a entrevista concedida a Hermano Vianna Jr., para a revista Caos, em 1990.

6 Informação fornecida por Arthur Dapieve, em 0 trovador soLitário (ver referências). 
saída do "Império da Razão", da frustração, e da obrigação de ser força-produtiva-atravésdo-trabalho (MARCUSE, 1968). Não se resignando ao modelo tecnocrata das sociedades industriais - modelo oficialmente imposto aos jovens de praticamente todo o mundo ocidental -, a cultura rock procura a liberação do prazer pelo acesso ao inconsciente coletivo e ao misticismo oriental, donde estariam os impulsos estéticos considerados primitivos, isto é, privados da cooptação e da manipulação pelas forças repressivas.

Além de todo esse processo complexo no qual se insere a produção de RR, há, também, a sua condição de homossexual (ou pansexual, como ele mesmo se autodenominou em entrevista à revista Isto É, de 27 de abril de 1994), que, como se sabe, não consegue facilmente um direito à sociabilidade nessa cartografia da música rock. O rock é, paradoxalmente, um lugar de busca de liberdade individual e, ao mesmo tempo, de demarcações heteronormativas, originárias da intensa liberação da energia yang ou polo masculino que, no Ocidente, se configura a partir de uma noção hegemônica de sexualidade. Essa cartografia, no entanto, não é estanque, pois, desde os primórdios do rock, podemos ouvir vozes e ler corporalidades capazes de inscrever em sua superficie as $d i-$ ferenças. O "jeito de corpo" (para usar uma expressão popularizada por Caetano Veloso, no álbum Outras palavras, de 1981) de Little Richard (1932), por exemplo, com seu 
visual andrógino e sua dança sexualizada, quebrou, desde o início, os padrões comportamentais polarizadores, chocando a classe média branca norte-americana da época para quem a demarcação entre masculino e feminino era bastante rígida.

Morrissey e Renato Russo são figuras controversas dentro do cenário da música rock e despertam tanto seguidores e fãs fiéis, quanto antipatias, raiva e desprezo. De modo geral, penso que a popularidade das letras de Morrissey e RR vem, em parte, pela performance ao vivo, em parte pela maneira singular que ambos encontraram de abordar o mito do amor: recortando particularidades que estavam à margem da pena da maioria dos outros letristas. Ambos politizam os afetos, a partir de uma tendência à melancolia que os coloca à parte do próprio cenário a que pertencem, numa espécie de "trovadorismo moderno", cuja inserção no universo da música rock - sobretudo com produções que fazem referências à cena punk, totalmente avessa a canções de amor - fez e faz um número considerável de moças e rapazes refletir sobre ética, política, sexismo, homoerotismo, amor e amizade.

O prestígio que esses letristas gozam, ainda hoje, junto ao seu público - que cresce e se modifica a cada ano - advém dessa articulação entre capacidade expressiva e autocrítica, que resulta num enquadramento lírico das questões abordadas, de modo a quebrar uma espécie de banalização muito comum no universo massificado da cultura rock. "Eles parecem um poço 
sem fundo", confessou, certa feita, um fã de ambos, para uma pequena matéria da MTV sobre as semelhanças entre os dois roqueiros. Poço sem fundo: sede sem fim. A configuração da melancolia de outsiders enquanto dispositivo de leitura e posicionamento no mundo traz, às letras e às performances, tanto de Morrissey quanto de Renato Russo, metáforas e imagens das mais belas produzidas na cultura rock, seguindo, assim, toda uma tradição que teria início com as narrativas de Joni Mitchell e Bob Dylan, desenvolvidas e ampliadas pelas singularidades de John Lennon, Jim Morrison, Lou Reed, Patti Smith, Leonard Cohen, entre outros.

Morrissey e Renato Russo têm uma história em comum, de anos de reclusão - no caso de $\mathrm{RR}$, colaboraram para isso os dois anos em que passou numa cadeira de rodas, vitimado por uma doença que ataca as articulações (epifisiólise). Ambos são devoradores de livros de filosofia, mitologia, ciências em geral, e, sobretudo, ficção e poesia; os dois são declaradamente leitores de Shakespeare e Fernando Pessoa; Morrissey, inclusive confessou recentemente ter retomado a leitura de O livro do desassossego, pelo qual tinha enorme admiração, apesar de perturbar-se com ele ${ }^{7}$. Também em entrevista, RR comentou sobre a presença da melancolia em seu processo criativo, mencionando a herança portuguesa como fator determinante dessa conexão. A melancolia em ambos os incentiva à criação, a

7 Declaração feita à revista $Q$, por ocasião do lançamento de You Are The Quarry, em novembro de 2006. Reproduzida em todos os fanzines e sites da Net, dedicados ao cantor. 
exemplo do que ocorre com os poetas barrocos, já estudados por Walter Benjamin, em A origem do drama barroco alemão (1984).

Movendo-se tanto nos espaços de penumbra, a que chamamos aqui de melancolia, quanto nos espaços de luminosidade, onde exercem sua potência ou vontade de afirmação da vida, Morrissey e $R R$ privilegiam a expressão de imagens e sentimentos de cunho romântico, pondo em circulação a ideia do roqueiro sensível e pária, inclinado a viver à margem da sociedade devido a um defeito de fabricação ou a um excesso de sensibilidade (não por acaso, Maladjusted é o título de um dos trabalhos solo de Morrissey), e fazem isso num mundo onde a expressão de sentimentos é, por vezes, vista como sinal de fraqueza. Contudo, nessa percepção de outsider, há espaço para a exaltação da alegria de estar vivo.

Tal celebração imprime um movimento interessante à condição melancólica, como se ela pudesse "dançar" e, com isso, deslocar a penumbra. Embora saibamos que Nietzsche era contrário ao culto da melancolia - por esse levar o pensamento e a arte europeia ao niilismo - é impossível não se lembrar de imediato da alegria de viver defendida por ele, em $A$ Gaia Ciência (2001), que consiste justamente nesse estado de bem-aventurança, em que criar é, sobretudo, um eterno estado de recriação de si e do mundo, uma dança de celebração da consciência de que estamos sozinhos, e, nessa solidão onde somos nossos próprios senhores, viver é um labor ao mesmo tempo ético e estético. 


\section{REFERÊNCIAS}

BENJAMIN, Walter. Origem do drama barroco alemão. Tradução de Sérgio Paulo Rouanet. São Paulo: Brasiliense, 1984.

CANCLINI, Néstor García. Consumidores e cidadãos: conflitos multiculturais da globalização. Tradução de Ana Regina Lessa e Heloísa Pezza Cintrão. Rio de Janeiro: UFRJ, 2001.

DAPIEVE, Arthur. 0 trovador solitário. Rio de Janeiro: Relume Dumará, 2001. (Série Perfis do Rio).

ENCICLOPÉDIA DO ROCK. São Paulo: Editora Três, [20--]. 3 v. (Edição especial da Revista Somtrês).

GROSSBERG, Lawrence. Dancing in spite of myself: essays on popular culture. London: Duke Universsity Press, 1997.

LEGIÃO Urbana. Legião Urbana. Rio de Janeiro: Emi-Odeon, 1985. (1) LP, CD sonoros (ca. $37 \mathrm{~min})$.

. Dois. Rio de Janeiro: Emi-Odeon, 1986. (1) LP, CD sonoros (ca. $38 \mathrm{~min}$ ).

. Que pais é esse? Rio de Janeiro: Emi -Odeon, 1987. (1) LP, CD sonoros (ca. $45 \mathrm{~min}$ ). 
LEGIÃO Urbana. Quatro estações. Rio de Janeiro: Emi-Odeon, 1989. (1) LP, CD sonoros (ca. $37 \mathrm{~min}$ ).

. V. Rio de Janeiro: Emi-Odeon, 1991. (1) LP, CD sonoros (ca. $40 \mathrm{~min}$ ).

. O descobrimento do Brasil. Rio de Janeiro: Emi-Odeon, 1994. (1) LP, CD sonoros (ca. $45 \mathrm{~min})$.

A tempestade. Rio de Janeiro: Emi-Odeon, 1996. 1) LP, CD sonoros (ca. $45 \mathrm{~min}$ ).

MARCUSE, Herbert. Eros e civilização: uma interpretação filosófica do pensamento de Freud. Tradução de Álvaro Cabral. Rio de Janeiro: Zahar Editores, 1968.

MORRISSEY. Entrevista a Nick Kent. reprod. Revista Bizz. São Paulo, p. 40-41, maio 1990.

. Viva Hate. Rio de Janeiro: EMI, 1988. 1) LP, CD sonoros (ca. $50 \mathrm{~min}$ ).

. Maladjusted. Los Angeles: Virgin, 1990. 1) LP, CD sonoros (ca. $35 \mathrm{~min}$ ).

MUGGIATI, Roberto. História do Rock. São Paulo: Somtrês, [s/d].

NIETZSCHE, Friedrich. A Gaia Ciência. Tradução de Paulo César de Souza. São Paulo: Companhia das Letras, 2001. 
PHILIPE, Gille; REY, Leopoldo. Livro negro do Rock. São Paulo: Somtrês, [s/d].

RUSSO, Renato. Que roqueiro é esse? Manchete, Rio de Janeiro, p. 196-200, nov. 1987. (Entrevista a Zélia Prado).

. Entrevistão com Renato Russo. Revista Bizz, Rio de Janeiro, ano 6, n. 6, ed. 59, p. 9, jun. 1990. (Entrevista a José Augusto Lemos). 1 CD ROM.

. Entrevista a Renato Lemos Dalto. O Estado, Florianópolis, p. 1, 17 jul. 1988. Disponivel em: <http://legiao.skooterweb.com/ entrevista/estado88.php\#.VRqI9hZgMmY>. Acesso em: 18 fev. 2013.

. Stonewall in Concert. Rio de Janeiro: EMI, 1992. (1) LP, CD sonoros (ca. 45 min).

Equilibrio distante. Rio de Janeiro: EMI, 1994. (1) LP, CD sonoros (ca. $45 \mathrm{~min}$ ).

THE SMITHS. The Smiths. Rio de Janeiro: Emi -Odeon, 1983. (1) LP, CD sonoros (ca. 45 min).

Meat is murder. Rio de Janeiro: Emi -Odeon, 1984. (1) LP, CD sonoros (ca. 45 min). THE SMITHS. The Queen is Dead. Rio de Janeiro: Emi-Odeon, 1985. (1) LP, CD sonoros (ca. $45 \mathrm{~min}$ ). 
THE SMITHS. Strangeways, here we come. Rio de Janeiro: Emi-Odeon, 1986. (1) LP, CD sonoros (ca. $45 \mathrm{~min}$ ).

. Hatful of hollow. Manchester: Roughtrade, 1984. (1) LP, CD sonoros (ca. $45 \mathrm{~min}$ ). THE SMITHS. Louder than bombs. Rio de Janeiro: WEA, 1987. (1) LP, CD sonoros (ca. $45 \mathrm{~min})$.

SOUZA, Antônio Marcus Alves de. Cultura, rock e arte de massa. Rio de Janeiro: Diadorim, 1995.

TALBURT, Shirley; STEINBERG, Susan (Ed.). Pensando Queer: sexualidad, cultura y educación. Barcelona: Graó, 2005.

VELOSO, Caetano. Outras palavras. Rio de Janeiro: PollyGram, 1981. (1) LP, CD sonoros (ca. $45 \mathrm{~min}$ ).

WILSON, Colin. Outsider: o drama moderno da alienação e da criação. Tradução de Margarida Maria C. Oliva. São Paulo: Martins Fontes, 1985. 


\title{
BIOGRAFEMAS HOMOCULTURAIS DE EVA PERÓN NO ROMANCE SANTA EVITA, DE TOMÁS ELOY MARTÍNEZ
}

\author{
André Luis Mitidieri ${ }^{1}$
}

O modo como o sujeito-autor se posiciona no discurso da crítica contemporânea pode variar: alguns adotam uma posição de distanciamento e outros se entrelaçam ao corpus escolhido, acompanhando o movimento de entrada e saída do gesto enunciativo. Viabilizam-se olhares diferenciados a gêneros menores, a uma tradição literária desviada do foco das grandes narrativas, processados através das margens e dos bastidores. Os centros acadêmicos não mais definem os critérios de preferência e valores estéticos, ao mesmo tempo em que momento atual apresenta critérios híbridos e mais abrangentes: "os cânones e a tradição literária atuam sorrateiramente sobre a experiência singular do fazer artístico, atividade secular que se nutre de revivals e revisitações" (SOUZA, 2002, p. 90).

1 Mestre e doutor em Letras, área de concentração em Teoria da Literatura, pela PUCRS. Professor Titular no Curso de Letras da Universidade Estadual de Santa Cruz (UESC). Docente de Literatura e História no Programa de Pós-Graduação em Letras - Mestrado em Linguagens e Representações (UESC). E-mail: 〈almpereira@uesc.br>. 
Ao mesmo tempo, a proliferação de práticas discursivas tidas como extrínsecas à literatura, a exemplo da

\begin{abstract}
[...] cultura de massa, as biografias, os acontecimentos do cotidiano, além da imposição de leis regidas pelo mercado, representam uma das marcas do nosso tempo, que traz para o interior da discussão atual, a democratização dos discursos (SOUZA, 2002, p. 90).
\end{abstract}

Nesse conjunto, e após longo expurgo por boa parte do século XX, a abordagem biográfica retorna aos estudos históricos, porém, não mais voltada às ações dos "grandes vultos da história", muito menos por intermédio da mera inserção de personalidades desse tipo em seus respectivos contextos, mas buscando analisar os principais eventos nos quais poderia estar envolvida.

De outro modo, os estudos histórico-biográficos contemporâneos têm em mente as relações entre acontecimentos, conjunturas e estruturas, elites e massas, individuos e grupos, palavra e ação. É pensando também na reestruturação do próprio gênero biográfico, de suas formas e de seus meios de viabilização nos estudos históricos, que François Dosse (2007) escreve La apuesta biográfica: escribir una vida. Nesse livro, o historiador destaca o conceito de "biografema", estabelecido pelo teórico homossexual Roland Barthes (1971, p. 12), quando aborda as representações pela linguagem através de um conceito tributário da noção de fonema: 
Se eu fosse um escritor, já morto, como gostaria que minha vida se reduzisse, pelos cuidados de um biógrafo amigo e desenvolto, a alguns pormenores, a alguns gostos, a algumas inflexões, digamos: 'biografemas', cuja distinção e mobilidade poderiam viajar fora de qualquer destino e vir tocar, à maneira dos átomos epicurianos, algum corpo futuro, prometido à mesma dispersão; uma vida furada, em suma, como Proust soube escrever a sua na sua obra, ou então um filme à moda antiga, de que está ausente toda palavra e cuja vaga de imagens (esse flumen orationis em que talvez consista 'o lado porco' da escritura é) entrecortada, à moda de soluços salutares, pelo negro apenas escrito do interstício, a irrupção desenvolta de outro significante: o regalo branco de Sade, os vasos de flores de Fourier, os olhos espanhóis de Inácio.

Vidas vividas juntam-se a sinais diversos, imagens, resíduos sígnicos, também indagando sobre a realidade, nos corpúsculos biografemáticos que Barthes (1990, p. 11) detecta em Fourier: "seu gosto pelos 'mirlitons' (bolinhos parisienses com aromatizantes), sua simpatia tardia pelas lésbicas, sua morte entre os vasos de flores". Essas formas residuais, esses cacos particulares da existência, depõem acerca do sujeito de uma forma singular:

[...] o que me vem de Loyola não são as peregrinações, as visões, as macerações e as constituições do santo, mas 
somente os seus belos olhos, sempre um pouco marejados de lágrimas. Porque, se é necessário que, por uma retórica arrevesada, haja no Texto, destruidor de todo sujeito, um sujeito para se amar, tal sujeito é disperso, um pouco como as cinzas que se atiram ao vento após a morte (ao tema da urna e da estela, objetos fortes, fechados, instituidores de destino, opor-se-iam os cavacos de lembrança, a erosão que só deixa da visa passada alguns vincos) (BARTHES, 1990, p. 12).

Tais vestígios permitem refigurar as muitas histórias que poderiam ter ocorrido, e não somente a história estabelecida. Operações metonímicas, como as que se viabilizam por intermédio do conceito de biografema, somam-se às considerações atuais quanto a uma historiografia da literatura que se nega à canonicidade fixa ou presa a um só contexto. Daí a presente atenção aos lugares móveis dos textos e a seus sentidos, em lugar dos enquadramentos unânimes, nacionais, lineares, uniculturais.

É assim que buscamos articular a ideia barthesiana de biografema à crítica cultural contemporânea, a fim de desenvolvermos a noção de "biografema homocultural", a partir do romance Santa Evita ${ }^{2}$, de Tomás Eloy Martínez, num momento em que o contexto his-

\footnotetext{
2 MARTÍnEZ, Tomás Eloy. Santa Evita. São Paulo: Companhia das Letras, 2006. Todas as citações do romance, aqui utilizadas, foram retiradas desta edição, e identificadas pelos respectivos números das páginas.
} 
tórico e suas interpretações auxiliam a compreender tudo aquilo que, à primeira vista, pode parecer inexplicável ou desconcertante. Lidando com modelos divergentes, podemos nos associar à reflexão sobre as diferenças entre um espelho (no singular) e os espelhos (no plural); quer se disponham "um em face do outro (imagem zen), de maneira a refletirem sempre o vazio, quer a multiplicidade dos espelhos justapostos cerque o sujeito com uma imagem circular cujo vaivém fica por isso mesmo abolido" (BARTHES, 1990, p. 129).

François Dosse (2007) menciona o tensionamento vivido por Roland Barthes, em 1971, quando escreve Sade, Fourier, Loyola, entre o rigor da teoria estruturalista e os prazeres da escritura mais liberta de técnicas rigidamente definidas. Nesse texto, como visto, Barthes constrói os sujeitos do enunciado, a partir de pequenos detalhes que muito revelam sobre as personalidades históricas; afastando-as da unicidade, faz jus às múltiplas posições que elas ocuparam no universo social, além de inovar na narração de vidas.

O uso de pormenores mais significativos rompe com a tradicional linearidade do gênero biográfico, oferecendo perspectivas parciais dos indivíduos, mas aptas a compor uma visão da pluralidade humana. Assim, o caráter não linear do biografema se fundamenta na mobilidade e na fluidez, oferecendo sinais entrecortados que proporcionam a materialização ou as interpretações da multiplicidade do indivíduo e das sociedades. A 
ideia de uma escrita biográfica menos maciça e mais indicial, portanto aproximada a então recente micro-história italiana (de Carlo Ginzburg, Giovanni Levi e Simona Cerutti, dentre outros), ganha destaque no sistema de pensamento do estudioso francês e nos estudos (auto)biográficos que, após longo ostracismo, voltam à cena teórica francesa, em meados dos anos 1970.

Tamanha importância adquire a noção barthesiana nesse contexto, de onde migra com sucesso para os centros universitários ocidentais, que retorna, em livro publicado originalmente no ano de 1980, Câmara clara (BARTHES, 1984, p. 153), estritamente vinculada com aquele instante ímpar de um sujeito, captado pela fotografia, quando,

[...] às vezes, faz aparecer o que ja-
mais percebemos de um rosto real (ou
refletido em um espelho): um traço
genético, o pedaço de si mesmo ou de
um parente que vem de um ascen-
dente. Em tal foto, tenho o 'focinho'
da irmã de meu pai. A Fotografia dá
um pouco de verdade, com a condição
de retalhar o corpo. Mas essa verdade
não é a do indivíduo, que permanece
irredutivel; é a da linguagem.

Para definir um dos vastos elementos capazes de explicar o interesse despertado por fotografias que, portadoras de um afeto médio, se fazem perceber com familiaridade devido à cultura moral e política ou ao saber do observador, mas sempre enviam a 
uma informação clássica, Barthes (1984, p. 45) utiliza-se do termo latino studium, "que não quer dizer, pelo menos de imediato, 'estudo', mas a aplicação a uma coisa, o gosto por alguém, uma espécie de investimento geral, ardoroso, é verdade, mas sem acuidade particular". O segundo elemento, por sua vez, parte da cena, à maneira de uma flecha; nomeado como punctum, "é também picada, pequeno buraco, pequena mancha, pequeno corte - e também lance de dados. O punctum de uma foto é esse acaso que, nela, me punge (mas também me mortifica, me fere)" (BARTHES, 1984, p. 46).

Em contraste com o studium, o punctum expressa a "zebrura inesperada que às vezes vinha atravessar esse campo" (BARTHES, 1984, p. 141) e, ao se desprender do detalhe, não sendo mais uma questão "de forma, mas de intensidade, é o Tempo, é a ênfase dilaceradora do noema ('isso foi'), sua representação pura" (BARTHES, 1984, p. 141). Tanto num quanto em outro caso, o punctum se associa intimamente ao biografema, conceito que há tempos integra o repertório e o vocabulário da teoria literária contemporânea, permitindo a reconstituição das formas e dos gêneros do espaço biográfico por intermédio da recorrência à imagem fragmentária do sujeito, cuja totalidade da vida é completamente impossivel de ser atingida por uma construção narrativa.

Desse modo, a escrita biografemática abrese à interpretação dos leitores que, por sua vez, refazem a imagem dos sujeitos biografados, a partir de associações fundadas em momentos 
de vida entrecruzados a outras existências e a outras avaliações. Como esta, outras formas de escrita biográfica não eliminam a hipótese de o sujeito produtor do discurso recorrer à imaginação para, inclusive, preencher vazios sobre acontecimentos aos quais não pôde ter acesso, mediado por documentos, fontes, rastros. No entanto, o jogo entre os elementos verídicos e a ficção irrecusável pode se restringir devido ao pacto (auto)biográfico, que, envolvendo autor e público leitor/receptor, parece reger as formas e os gêneros integrantes do "espaço biográfico", assim denominado por Leonor Arfuch (2010).

Devido principalmente às possibilidades que apresenta de proceder a desvios, em relação ao cânone literário e às hierarquizações da história oficial, é que a noção de biografema se conjuga à "homocultura" enquanto lócus de estudo e representação de expressões culturais, produzidas por sujeitos homossexuais e/ ou a seu respeito, bem como das visões e dos diálogos que proporcionam, a partir da ruptura com os discursos hegemônicos e da crítica às heteronormatividades.

Nesse âmbito, representações biográficas, históricas e literárias de Eva Perón, elaboradas por Juan José Sebreli (1966), Manuel Puig (1966), Osvaldo Lamborghini (1969) e Raúl Natalio Roque Damonte Botana Taborda, o Copi (1970), inovavam ao mostrar as ambivalências do fetiche, evocado pelo nome de Eva e pela face camp da atriz a se desempenhar nos palcos do poder. Entre a "guerra suja" (1976-1983) que marcou a era ditatorial na Argentina e a futura 
redemocratização do país, outros acréscimos a sua imagem; alguns que satisfazem a curiosidades privadas; outros que mais ainda a deslocam das margens da sociedade militarizada e patriarcal sobressaem nos textos de autoria homossexual dedicados à "Dama da Esperança", por seu costureiro Paco Jaumandreu (1975; 1981), pela poetisa María Elena Walsh (1976) e pelo escritor Néstor Perlongher (1975, 1980, 1983, 1989).

David William Foster (1999, p. 529) ressalta, dentre as várias configurações assumidas pelo ícone de Evita, no imaginário social do Rio da Prata, a sua identificação como figura de proa para a cena LGBT no período pósditatorial:

'Si Evita viviera, seria tortillera'. Con este tropo, tomado del grito de combate del movimiento guerrillero de la izquierda argentina, 'Si Evita viviera, sería montonera', el naciente movimiento gay de los ochenta (el cual fue posible solamente gracias a la redemocratización de la post-dictadura y la determinación de Argentina de ser absolutamente moderna) intentó reclamar a Eva Duarte de Perón como un potente simbolo ${ }^{3}$.

3 "'Se Evita vivesse, seria sapatão'. Com esse tropo, tomado de empréstimo do grito de combate do movimento guerrilheiro da esquerda argentina, 'Se Evita vivesse, seria montonera', o nascente movimento gay dos anos 1980 (que se fez possível graças somente à redemocratização da pós-ditadura e à determinação da Argentina a ser absolutamente moderna) tentou reclamar Eva Duarte de Perón como um potente símbolo” (FOSTER, 1999, p. 529 - tradução nossa). 
O desvelamento da mulher como um "ícone da inscrição da Argentina no texto da modernidade periférica", paralela a sua atuação, fosse primeiramente como atriz, fosse mais tarde como liderança politica que usou e abusou dos meios de comunicação de massa, principalmente do rádio, entrelaça-se a uma experiência coletiva, conforme lembra Susana Rosano (2005, p. 274-275). Do corpo que jogou papel fundamental na entrada do peronismo em cena e na inscrição do populismo platino junto ao imaginário modernizador nacional, o tropo de Eva Perón:

[...] se articula a una serie de indagaciones experimentales que eligen interrogar al personaje desde una pregunta desestabilizadora: su condición de mujer. Desde alli surgen reinvenciones que paradójicamente convierten a este icono del nacionalismo en una figura marginal de tintes posmodernos. El performance de Evita se reviste asi con los colores estridentes de la estética camp y de alli surgen imágenes sorprendentes de una Eva travesti, lumpen, fiestera, absolutamente marginal a las sintaxis explicativas que previamente habian articulado los discursos tanto de la ortodoxia peronista como de la oposición liberal ${ }^{4}$.

\footnotetext{
4 "[...] articula-se a uma série de indagações experimentais que optam por interrogar a personagem desde uma pergunta desestabilizadora: sua condição de mulher. Desde então surgem reinvenções que paradoxalmente convertem esse ícone do nacionalismo em uma figura marginal de matizes pós-modernos. A performance de Evita reveste-se assim com as cores estridentes da estética camp e daí surgem imagens surpreendentes de uma Eva
} 
Levando isso em conta, a ideia de "biografema homocultural" permite-nos analisar a tradução brasileira do romance de Tomás Eloy Martínez, intitulado Santa Evita (1996). Assim, em uma das várias inserções metatextuais a que procede, o autor nos informa que, em Eva Perón, drama de Copi encenado pela primeira vez em Paris, no ano de 1970, "Evita mostrava a bunda. Na peça ela oferece seu amor como pode ou como sabe" (p. 173). Entretanto, trata-se de um poder amputado e de um saber controlado, pois o dramaturgo elide os materiais da Evita revolucionária, trazendo para seu lugar o julgamento e a desqualificação, promovidos pelos antiperonistas da década de 1950, segundo Beatriz Sarlo (2005, p. 237).

Caso tomássemos a frase de Martínez ao pé da letra, as possibilidades e os conhecimentos amorosos de Eva, no referido drama, se restringiriam ao seu derriére. A lembrança do passado da protagonista "não serve de base para um sentimentalismo generoso, e sim para um conhecimento desencantado e cínico da vida" (SARLO, 2005, p. 19). Sem negar a classe média antiperonista, de onde provém, e para a qual a mulher de Perón era nada mais do que a intrusa, a prostituta, a ressentida, Copi

[...] trabalharia com esses discursos da infância e, naturalmente, imprime a

travesti, lumpemproletária, festeira, absolutamente marginal às sintaxes explicativas que previamente haviam articulado os discursos tanto da ortodoxia peronista como da oposição liberal” (ROSANO, 2005, p. 274-275- tradução nossa). 
eles um tom paródico, mas não no sentido da revolução política, e sim no de um populismo marginal que diz: tudo bem, na Rosada tem uma puta que veste Dior, e daí? (SARLO, 2005, p. 238).

Talvez as fotografias mais lembradas de Eva Perón sejam mesmo aquelas em vestido de gala que, sendo ou não da Casa Dior, tornavam-se capazes de unir a pompa típica das marchas, que caracterizaram os regimes totalitários, na década de 1940, ao glamour de divas do cinema, como Dorothy Lamour, María Félix e Rita Hayworth. Os braços à mostra e o discreto decote converteram-se no detalhe interessante que, sem ser rigorosamente intencional, mas ao mesmo tempo inevitável,

$[\ldots]$ não atesta obrigatoriamente a
arte do fotógrafo; ele diz apenas ou
que o fotógrafo se encontrava lá, ou,
de maneira mais simplista ainda, que
ele não podia não fotografar o objeto
parcial ao mesmo tempo que o objeto
total (BARTHES, 1984, p. 76).

Esse punctum gracioso vem sendo reproduzido à exaustão nos corpos, fotografias, celuloides e imagens digitais das atrizes que interpretaram Evita na ópera-rock e na grande tela, desde Julie Covington e Elaine Page a Paloma San Basilio e Nacha Guevara; de Madonna a Esther Goris. O famoso exemplar da fotogenia evitista, e da propaganda do populismo peronista, configura um biografema 
que, como a Eva de Copi, em simultâneo combate à morte e em cuidadoso preparativo ao espetáculo no qual se converteria seu enterro, longe está da "miniatura sentimentalista do kitsch, [...] tem a grandiosidade acessivel do melodrama e do camp" (SARLO, 2005, p. 21).

Os trajes de gala e as unhas pintadas precisam de sua utilização "como atributo porque, como se sabe, são uma dimensão fundamental da personagem (teatral e politica)" (SARLO, 2005, p. 21). Os atos de teatralizar, ordenar, articular e isolar-se integram as funções que Barthes (1990) identifica nas espécies de linguas diferenciadas, a seu ver, fundadas nas respectivas escritas de Loyola, Fourier e Sade. A tomar como parâmetro o contexto norte-americano, a cultura homossexual anterior aos protestos de Stonewalll, portanto precursora dos movimentos gays e lésbicos do final dos anos de 1960, também necessitou isolar-se em guetos que, por outro lado, funcionavam como articulação com outros similares entre si em seus desvios à norma e à "normalidade".

Aqui, algumas pessoas, determinados grupos, ordenavam as formas de resistência à repressão, "bien fuera en la literatura y el teatro o sencillamente en la creación y el mantenimiento de espacios de sociabilidad $y$ solidaridad (bares, lugares de encuentro, asociaciones, etc.) (ERIBON, 2000, p. 29) ${ }^{5}$. Além

\footnotetext{
5 “[...] seja na literatura, seja no teatro, ou simplesmente na criação e na manutenção de espaços de sociabilidade e solidariedade (bares, lugares de encontro, associações, etc.)" (ERIBON, 2000, p. 29 - tradução nossa).
} 
de criarem suas gírias e seus jargões nesses locais de socialização, os homossexuais aí formavam e compartilhavam determinados gostos por certas expressões culturais.

O camp, por exemplo, sensibilidade estética da arte popular logo apropriada pela indústria cultural, angariou a predileção dos que adotavam como defesa a sua lógica do cru sarcasmo ou da exagerada crueldade e, como meios de diversão, o excesso, a imitação, a repetição e o travestismo (SONTAG, 2004). Muitas vezes, a própria presença do homossexual no espaço público pronuncia-se sob a forma da "bicha fechativa", excessiva em sua fala e em seu gestual, enquanto shows de dublagens protagonizados por drag queens, transformistas ou travestis fazem-se bastante comuns nos ambientes gays.

Um dos traços camp por excelência, muito presente na homocultura, o arremedo, pode ser observado nos seguintes vestígios da história que, ao mesmo tempo, funcionam como intertextos do universo ficcional de Martínez (2006), nos quais Evita imita ou é imitada: a ópera de Tim Rice e Andrew Lloyd Weber; a canção Don't cry for me Argentina, nas vozes de Sinnead O'Connor e Janice Brown; os filmes dos quais participara Eva Duarte: La pródiga, La cabalgata del circo e El más infeliz del pueblo. Por sua vez, a protagonista do drama de Copi grita para não ser transformada em estátua ou em pintura, enquanto Perón afirma que sua imagem haverá de ser reproduzida ao infinito. 
A repetição própria do camp atinge o musical Evita, constantemente em novas temporadas ao redor do mundo, e as reproduções da figura da protagonista, ornada com a auréola da estátua da Liberdade. Tal característica parece assimilada pelo autor de Santa Evita, quando relaciona uma frase constante nos panfletos que sucederam o atentado ao teatro parisiense, L'Epeé-de-Bois, onde o espetáculo de Copi havia estreado - "Que falta de respeito, que atropelo à boa razão" (p.173) - ao ocorrido com Néstor Perlongher no momento em que, devido à publicação dos três contos de Evita vive, "outros fanáticos invocaram o mesmo tango de [Enrique Santos] Discépolo ao processá-lo por 'atentado ao pudor e profanação': Que falta de respeito, que desplante de maldade insolente" (p. 174, grifos do autor).

O diálogo que o romance em tela empreende com a crítica literária esquadrinha um tipo de referência biografemática na qual ingressam, ao mesmo tempo, um intertexto ficcional - são uma epifania no sentido que Joyce dava à palavra: "uma súbita manifestação espiritual', a alma de um corpo ávido que ressuscita (p. 174) - e outro filosófico: “o que revela é o corpo de uma alma, ou o que Leibniz chamaria de 'o corpo de uma mônada"' (p. 174, grifos do autor). A intertextualidade firmada com as narrativas ficcionais Evita vive e El cadáver de la nación, de Perlongher, destaca a escritura como diferença. Partes desses textos são transcritas para o texto de Martínez, que ainda recontextualiza o "sacrilégio" do sujeito 
produtor ao identificar o primeiro dos textos referidos como paródia de um livro sagrado: o Evangelho segundo São João, capítulo XX, versiculos 14 e 27.

A intertextualidade encadeada, por meio da qual a narrativa em estudo repete de outra forma uma série de obras biográficas, históricas e literárias, substitui a relação autor-texto pela relação leitor-texto: "Alguns dos melhores relatos dos anos 50 são o relato de sua morte" (p. 172). O mesmo pavor que Eva Perón gerou em vida passaria a ser inspirado pelo espetáculo de sua morte que, antecipando os funerais de Judy Garland, outro ícone gay, tornou-se capaz de intimidar as elites "com sua intimidade, exagerada, gritante, a malandra, Evita, a deslavada" (p. 172).

As representações da primeira dama do peronismo, levadas a bom termo por escritores homossexuais, segundo Martínez, contemplam as ambivalências de sua imagem: "Eles a chupam, a ressuscitam, a enterram, enterram fundo nela, a idolatram. São Ela, Ela até a exaustão" (2006, p. 172). Como sabido, o autor-narrador refere-se ao drama de Copi e aos textos nos quais Perlongher demonstra uma vontade de ser Evita,

[...] não se atreve a tocar sua vida e, por isso, toca sua morte: ele apalpa o cadáver, o cobre de joias, o maquia, depila seu buço, desmancha seu coque. Ao contemplá-la de baixo, a endeusa. E como toda Deusa é livre, ele a desenfreia (MARTÍNEZ, 1996, p. 174). 
No entanto, David William Foster (1999) pondera que não fica muito claro como é que o desejo de manter relações sexuais com o corpo de Eva Perón possa ser descrito como um ato gay, embora não deixe de corresponder a uma interpretação cultural válida. O que gera interesse para a homocultura é o encampamento de sua figura, até hoje copiada ad infinitum, por atrizes da grande tela, mulheres na política e travestis dos pequenos shows de prénoitadas, entreatos ou after-hours. O travestimento de Eva faz-se entender não somente por intermédio do uso ostensivo das vestimentas do outro, mas também como qualquer

[...] tipo de vestido o fenómeno parecido que representa estructuras de articulación disidente: adornos del cuerpo, lenguaje corporal, forma de habla afectiva, discurso narrativo y ubicación especial como 'perversiones' de lo putativa e ideológicamente impuesto como 'natural'.

Nesse sentido, a hegemonia apenas tolera os homossexuais e as lésbicas que apresentarem comportamentos discretos. Uma das piores consequências dessa regulação é que, assim, se dispõem a:

\footnotetext{
6 "[...] tipo de vestido ou semelhante fenômeno que representa estruturas de articulação dissidente: enfeites do corpo, linguagem corporal, forma de fala afetiva, discurso narrativo e localização especial como 'perversões' daquilo que é putativa e ideologicamente imposto como 'natural'" (FOSTER, 1999, p. 530-531 - tradução nossa).
} 
[...] reproducir el modelo normativo con el fin de obtener respeto social. El precio implica esconder, entre otros, a los chaperos, a las locas y a las camioneras. El precio es formar pareja estable (o mejor aún: casarse y tener hijos), olvidar el sadomasoquismo, y jamás (jjamás!) hablar de relaciones intergeneracionales. De este modo triunfa una sofisticada tecnología de control social que pretende difundir el modelo heteronormativo entre los y las disidentes ${ }^{7}$.

Até boa parte do século XX, regulações desse tipo atingiam também as mulheres, a julgar pela ausência mais do que sentida, em inúmeras obras biográficas e históricas sobre Eva Perón, da referência ao sexo, que ela mesma queria apagar de sua história particular. De certa forma, os mitos gerados por sua figu$\mathrm{ra}^{8}$ obtiveram tal propósito; silenciando sobre o assunto ou difamando a suposta prostituta, acabaram por sacralizar a sexualidade da personalidade histórica que os tinha origina-

\footnotetext{
7 [...] reproduzir o modelo normativo a fim de obter respeito social. O preço implica esconder, dentre outros, os michês, as bichas-loucas e as camioneiras. o preço é formar união estável (ou melhor ainda: casar-se e ter filhos), esquecer o sadomasoquismo, e jamais (jamais!) falar de relações intergeracionais. Desse modo, triunfa uma sofisticada tecnologia de controle social que pretende difundir o modelo heteronormativo entre os e as dissidentes (ERIBON, 2000, p. 11 - tradução nossa).

8 Segundo o "mito branco", Evita era a virgem em pessoa, a mártir, "síntese e paradigma de todas as mães, a mater doLorosa" (ORTIZ, 1995, p. 338). o "mito negro" obscureceu "essa mulher" com a sombra da ressentida, da prostituta, da "alpinista social", sedenta de poder. Já o "mito vermelho" decorre da apropriação de sua imagem pelos Montoneros, uma das facções guerrilheiras que abrigavam os novos peronistas de esquerda durante os anos de 1970.
} 
do. No conteúdo do romance em análise, para cuja interpretação o sistema referencial tornase auxiliar muito eficaz, uma composição poética não nomeada serve como termo de comparação com a postura de alguns escritores homossexuais em face da imagem de Evita: "Só as bichas-loucas da literatura a inflamam, a desnudam, bolem com ela, como em um poema de Oliverio Girondo" (p. 175).

Entretanto, se a audácia desse poeta opera como precursora da literatura maldita de Perlongher, não é com a diva da indústria ou da comédia musical nem com a drag, tampouco com os ícones da cinematografia camp, tais como Elizabeth Taylor, Joan Crawford e Mae West que a Eva Perón de Copi mais se identifica, e sim com a literatura antiperonista:

En general, una escritura de hombres, que no puede asir el fenómeno del amor odio que despertaba Evita y que revela la imposibilidad de su representación, desde otro punto de vista, que el modo dicotómico del melodrama, por el cual, o es demonizada o canonizada [...] (BURGOS, 2007, p. 68) ${ }^{9}$.

Segundo a análise metatextual de Martínez em Santa Evita, várias escritas ficcionais,

9 Em geral, uma escritura de homens que não pode assegurar o fenômeno do amor ódio que Evita despertava e que revela a impossibilidade de sua representação a partir de um outro ponto de vista que não fosse o modo dicotômico do melodrama pelo qual ou é demonizada ou é canonizada (BURGOS, 2007, p. - tradução nossa). 
baseadas em Evita, prestam-se à estruturação do mito negro e à desestruturação do mito branco, construídos em torno de sua imagem. Então, o que subjaz à ironia de Julio Cortázar, em El examen - "Ela é boa, ela é muito boa, repetem os cabecitas negras que invadem a cidade e acabam transfigurados em fungos e brumas venenosas" (p. 171) - aparece explicitamente no Libro negro de la segunda tiranía, obra anônima: "Aquela estranha mulher era diferente de quase todas as interioranas [...] era veemente, dominadora e espetacular" (p. 171). Ambos os textos citados ligam-se às $\mathrm{Ca}$ tilinárias, de Martínez Estrada: "Devia gostar de fêmeas [...] Ter o descaramento das mulheres públicas na cama, a quem dá na mesma refocilar-se com um habitué de bordel, com uma mascote doméstica ou outra pupila da casa" (p. 171-172).

Esses livros unem-se no repúdio ao "sexo insano" da heroína, vinculando-se à mesma exclusão operada pelas vertentes míticas. O "despudor" de Evita consistiria em infundir, com sua latência erótica, com sua fúria vital, um pavor à sociedade machista em cujos lares as mulheres poderiam converter-se numa ameaça, pois espelhadas naquela que

saía da escuridão da toca e deixava de bordar, engomar as camisas, acender o fogo, preparar o mate, dar banho nas crianças, para se instalar nos palácios do governo e das leis, que eram domínios exclusivos dos homens (p. 171). 
Desse modo, o escritor uruguaio Juan Carlos Onetti e o argentino Jorge Luis Borges, em seus respectivos contos "Ella" e "O simulacro", têm a intenção de esconjurar o fantasma da esposa de Perón, evidenciando a barbárie que representava seu culto, prestado pelos "negros" das provincias e pelos pobres dos subúrbios. Porém Martínez infere que, sem querer, Borges homenageia a imensidão da protagonista porque, no conto "O Simulacro", "Evita é a imagem de Deus mulher, a Deus de todas as mulheres, a Homem de todos os deuses" (p. 172). Daí que a literatura, restrita ao corpo morto e ao sexo insano da heroína em escrituras masculinas, assim resulte ampliada, embora a contragosto.

Não é apenas no desejo capaz de deslocar ou realocar as significações do feminino e do masculino, da vida e da morte, que reside a importância das obras de Copi e Perlongher, sobre as quais Adrián Melo, em El amor de los muchachos: homosexualidad y literatura, afirma:

[...] parecen asimilar, apropiarse y reinterpretar diversos simbolos y elementos a partir de los cuales se ha construido el mito de Evita: la radio y el cine, la cabellera rubia, el rodete, las joyas y los sombreros, las máquinas de coser, las frazadas, la demagogia $y$ el autoritarismo, las armas compradas al principe de Holanda para armar a la clase trabajadora, la simulación y el travestismo (Martinez Estrada y Borges dirian que Eva era un macho), el cáncer, los funerales como espectáculo melodramático, el esmalte Revlon de las uñas del cadáver, la necesidad de 
derramar la propia sangre para entrar en la historia argentina, la instrumentación politica de la muerte, el maquillaje, el auténtico dolor de miles de humildes que sintieron que sus vidas no volverian a ser las mismas con la ausencia de ella ${ }^{10}$.

O sucesso de público, angariado pelas produções melodramáticas que ganham veiculação pelas distintas formas da cultura de massa latino-americana, parece responder ao enraizamento de alguns dos seus elementos, tais como a pobreza e a riqueza, o bem contra o mal, no imaginário coletivo. Sendo o melodrama uma forma vital de imaginação e uma prática relacionada à modernidade, em que sobressaem a dimensão simbólica, a emocionalidade e o gestual, como infere Peter Brooks (1976), o seu êxito na Argentina, onde impregnou a radionovela, o radioteatro e o cinema dos anos 1930/1940, não se descura de uma nova realidade sociocultural proporcionada pelo populismo peronista.

10 "[...] parecem assimilar, apropriar-se e reinterpretar diversos símbolos e elementos a partir dos quais se construiu o mito de Evita: o rádio e o cinema, a cabeleira loura, o coque, as joias e os chapéus, as máquinas de costura, os cobertores, a demagogia e o autoritarismo, as armas compradas ao príncipe da Holanda para armar a classe trabalhadora, a simulação e o travestismo (Martínez Estrada e Borges diriam que Eva era um macho), o câncer, os funerais como espetáculo melodramático, o esmalte Revlon das unhas do cadáver, a necessidade de derramar o próprio sangue para entrar na história argentina, a instrumentação política da morte, a maquiagem, a autêntica dor de milhares de humildes que sentiram que suas vidas não voltariam a ser as mesmas depois da ausência dela” (MELO, 2005, p. 240 - tradução nossa). 
Desse modo, ao redor de Eva Perón, montava-se uma particular forma de hibridismo cultural em que:

[...] las lógicas de representación del Estado se tiñeron con las de la industria cultural y adquirieron el formato melodramático. El cuerpo, vivo y muerto, de Eva traspasó los mecanismos peronistas de control, superó ese efecto de 'balcón' al que se refiere Jon Beasley-Murray como el limite necesario que el populismo impone a las masas. Sólo ella fue capaz de entremezclarse con la multitud, y ganarse asi en el imaginario popular un lugar de leyenda ${ }^{11}$.

De acordo com Adrián Melo (2005, p. 238), não podemos compreender Evita, sua linguagem e sua oratória, se não levarmos em conta seu passado no radioteatro e na cinematografia argentina. Sua vida apresenta uma série daqueles sentimentos que garantiam a exitosa recepção do folhetim popular: a pobreza, o abandono, a queda, a vingança, a redenção. O melodrama vivido por ela se concluiria de forma camp, com a exposição pública de sua agonia em meetings do regime e nas inúmeras

11 "[...] as lógicas de representação do Estado tingiram-se com as da indústria cultural e adquiriram o formato melodramático. o corpo, vivo e morto, de Eva ultrapassou os mecanismos peronistas de controle, superou esse efeito de 'sacada' ao qual se refere Jon Beasley-Murray como o limite necessário que o populismo impõe às massas. Somente ela foi capaz de se entremesclar com a multidão, e assim conquistar, no imaginário popular, um lugar de lenda” (ROSANO, 2005, p. 19 - tradução nossa). 
reproduções que, junto a demonstrações de dó e piedade, multiplicavam-se por entre fotos e vídeos da recente televisão nacional.

Como mediadora entre o povo e os discursos da ordem peronista, Eva se valeu de sua experiência com o melodrama, talvez mais como receptora do que como intérprete, por exemplo, de famosas heroínas da história universal, tais como Ana da Áustria, Catarina, a Grande e Madame Lynch. Assim, não se mostraria desprezivel, segundo avalia Alejandro Susti González (2007), a reutilização de dispositivos de sedução própria das notações culturais populares, como o suspense, a estrutura aberta do texto, a confusão relato-vida, realidade-ficção, responsáveis por criar maior intimidade com os destinatários, sobretudo dos discursos públicos e radiofônicos, bem como da propaganda oficial impressa e radiotransmitida.

Para Susti (2007), o grande trunfo de Eva Perón, conquistado a partir do contato que travou com o imaginário produzido pela cultura popular de massas, consiste em ter sido modelo de uma trajetória à qual todo homem e, então, toda mulher das classes médias e populares podiam aspirar, desde o momento em que seu ingresso numa modernidade pelo menos periférica (SARLO, 1988) havia sido facilitado pelos mass media, especialmente pela publicidade, já nas décadas anteriores ao peronismo. No julgamento de David William Foster, o atrativo básico daquela líder carismática 
[...] ha sido el de la mujer fuerte, capaz de aumentar el poder que le permite desafiar a la sociedad machista, adoptando a menundo los signos exteriores mismos del poder del macho. Aún así, la mujer no se convierte en macho, sino que lo desplaza a través del gesto deconstructivo de una presencia cuidadosamente elaborada que pone en tela de juicio la 'la naturalidad' de la pose masculinista, y al mismo tiempo señala cómo el poder y la presencia son construcciones complejas que conllevan comportamientos igualmente complejos ${ }^{12}$.

A complexidade abarcada por Eva Perón (como primeira-dama e militante política, como pobre e logo rica, como a garota que queria ser atriz ao estilo de Norma Shearer e a benfeitora social de atuação recriminada ou louvada) resulta de uma autoinvenção que muito deve ao seu aprendizado com as textualidades da cultura de massa, principalmente daquela que, saída do campo, há pouco se instaurava nos centros urbanos ou às suas margens. Esse processo pouco tem a ver com a "cidade letrada" de Borges, Cortázar, Martínez-Estrada e Onetti, mas guarda algum débito para com o gênero textual do conto de fadas, de algum

12 "[...] foi o da mulher forte, capaz de aumentar o poder que the permite desafiar a sociedade machista, adotando com frequência os mesmos signos exteriores do poder do macho. Mesmo assim, a mulher não se converte em macho, mas o desloca através do gesto desconstrutivo de uma presença cuidadosamente elaborada que põe em questão 'a naturalidade' da pose masculinista e, ao mesmo tempo, assinala como o poder e a presença são construções complexas que implicam comportamentos igualmente complexos” (FOSTER, 1999, p. 530 - tradução nossa). 
modo, presente no imaginário popular, ainda que nunca lido em texto escrito:

Cada um lê o mito do corpo como quer, lê o corpo de Evita com as declinações de seu olhar. Ela pode ser tudo. Na Argentina ela ainda é a Cinderela das telenovelas, a nostalgia de ter sido o que nunca fomos, a mulher justiceira, a mãe celestial (p. 176).

\footnotetext{
Convém recordar, com Foster (1999, p. 530), que
}

El cuento de la Cenicienta respecto a alguien como Evita es homólogo al programa de construcción personal - el cuerpo y la identidad sexual como trabajo progresivo - que es tan importante para la sensibilidad gay ${ }^{13}$.

Não menos importante é a figura da mulher poderosa que, relacionada à protagonista de Santa Evita, remete à literatura infantojuvenil, aqui mediada pela interpretação psicanalítica. Essa outra forma de biografema homocultural apresenta-se no discurso do coronel Moore Koening, responsável pela guarda do cadáver embalsamado de Eva, o qual projeta nela a figura masculina do sedutor perigoso (Cf. BETTELMEIM, 1980, p. 201) que se

\footnotetext{
13 "A história da Cinderela transposta a alguém como Evita torna-se homóloga ao programa de construção pessoal - o corpo e a identidade sexual como trabalho progressivo - que é tão importante para a sensibilidade gay” (FOSTER, 1999, p. 530 - tradução nossa).
} 
transforma, caso o permitam, em destruidor da bondade nos contos de fadas:

Uma criada com pretensões a rainha. Agressiva, nada feminina. Coberta de joias da cabeça aos pés para se desforrar das humilhações que viveu. Ressentida. Inescrupulosa. Uma vergonha (p. 117).

Outra personagem de certa constância nos contos maravilhosos, o caçador empresta a presença responsável e salvadora, associada a sua figura, a fim de revelar as propensões altruístas e protetoras que os descamisados argentinos atribuem a sua benfeitora:

Sabia que, depois de sua morte, as cartas pedindo vestidos de noiva, móveis, empregos, brinquedos, o diabo a quatro, deviam ir em seu nome para obterem resposta (p. 117).

Morta, Evita retira seu poder dos dois principais mitos erigidos em torno de sua breve existência, pois na literatura, do mesmo modo que nos contos de fadas, a morte prematura do herói “- à diferença da morte de uma pessoa idosa, depois de ter vivido - simboliza o fracasso" (BETTELHEIM, 1980, p. 216) do ser humano frente ao tempo.

Trata-se menos de especular quanto poder teria se viva fosse, e mais de desvendar os significados de sua postura no contexto hipermasculinista e homofóbico da Argentina dos anos de 1940 e 1950, segundo David William 
Foster (1999, p. 531), para quem,

La alianza entre la Evita histórica e iconográfica y el movimiento gay - y aún queda por determinar si Evita es una imagen potente para un segmento de los gays masculinos para quienes la mujer poderosa tiene significado o para las lesbianas que pueden apreciar su reto al privilegio masculinista - es también una cuestión de proyecciones interpretativas ${ }^{14}$.

Em diversas narrativas históricas e versões ficcionalizadas que tentam interpretar sua vida, ela teria ajudado a dar à luz uma nova Argentina, sem a consumação do ato sexual (como a Virgem Maria). O passado de humilhações evocado por seus detratores, tal e qual o beijo ao sapo nos contos de fadas, revela-se como a busca de uma identidade que, antes de pessoal, é social. Desvelada na ficção biográfica, Eva Perón encarna "a nostalgia de ter sido o que nunca fomos, a mulher justiceira, a mãe celestial. Fora do país, é o poder, a morta jovem, a hiena compassiva declamando nos balcões do além: 'Não chores por mim, Argentina" (p. 176).

No Condado do Sexo Médio (ou do MeioSexo, ou do Sexo Medíocre), subúrbio norte

\footnotetext{
14 "A aliança entre a Evita histórica e iconográfica e o movimento gay - e ainda falta determinar se Evita é uma imagem potente para um segmento dos gays masculinos para o qual a mulher poderosa encontra significado ou para as lésbicas que podem apreciar sua provocação ao privilégio masculinista é também uma questão de projeções interpretativas" (FOSTER, 1999, p. 531 - tradução nossa).
} 
-americano onde Martínez escreveu o romance em estudo, Evita é "tão familiar como a estátua da Liberdade, com a qual, de quebra, ela se parece" (p. 176). Na voz de Sinnead O'Connor, cantora cuja cabeça raspada exprime um visual andrógino e cujas verbalizações marcaram-se por protestos às politicas do centro euro-americano de poder, Tomás Eloy Martínez reconhece a voz de Eva Perón: ambas, com "erres arrastados e ruminantes, pronunciam 'Arghentina' como se o gê fosse um erre da minha provincia natal" (p. 176). Em New Jersey, "ninguém sabe quem foi a Evita da realidade; a ópera de Tim Rice a popularizou, embora muitos americanos possam imaginar que a Argentina seja um subúrbio de Guatemala City" (p. 176).

Contra essa visão de um centro hegemônico, e com o fogo no qual Eva deixou seu nome, o autor escreveu o nome de seu distante país, visto de fora, mas também de dentro, e das margens, ainda que desde um centro, onde ia "avançando, dia após dia, pelo frágil fio entre o mítico e o verdadeiro, deslizando entre as luzes do que não foi e as sombras do que poderia ter sido. Vou perdendo-me nesses meandros e Ela sempre me encontra" (p.177). Mesmo ao fornecer biografemas do ícone camp, da heroína melodramática e da mulher poderosa na espécie de critica metatextual a que procede em seu romance, Martínez recorre ao imaginário cristão ocidental, às narrativas sólidas da teoria literária, da filosofia, do mito e da própria literatura canônica. 
Apesar da extrema boa vontade em sua abordagem às damas de papel reconstruídas pela escritura gay argentina, talvez resultante do manejo da epistemologia contemporânea, em especial da estética pós-modernista, devido a sua atuação como professor, em universidades norte-americanas, falta-lhe o corpo-acorpo com a homocultura para empreender análises mais amplas das vinculações entre a figura de Evita, a dicção ficcional homoerótica e as expressões homoculturais. Por tal razão, necessitamos aqui suplementar, com apoio em estudiosos do tema, as perspectivas do autor que ora revisamos, pois da mesma forma que Eva Perón, na breve vida por ela vivida, expôs com exagero seus luxos, "uma fantasia, um jogo burguês, nada mais, as regras do cerimonial" (RICE, 1997, p. 18), como canta a protagonista da ópera de Andre Lloyd Weber e Tim Rice, "el sujeto sexual marginado puede juzgar necesario o ventajoso exagerar la diferencia, disidencia y desviación, lo cual es, en gran parte, el poder significante de la screaming queen“ (FOSTER, 1999, p. 531) ${ }^{15}$.

Os mesmos desafios à norma e ao normatizado evidenciam-se nas conhecidas irritações e pirraças de Evita, em "sus lapsus estratégicos con lenguaje de bar y prostíbulo, su negativa a adherirse al protocolo consagrado"16. Esses traços

15 "[...] o sujeito sexual marginalizado pode julgar necessário ou vantajoso exagerar a diferença, dissidência e desviação que é, em grande parte, o poder significante da screaming queen [a bichinha cheguei]" (FOSTER, 1999, p. 531- tradução nossa).

16 “[...] seus lapsos estratégicos com linguagem de bar e pros- 
aparecem na dessacralização da mulher realizada pelas protagonistas de Perlongher, mas não pela de Copi, que até mesmo ao lhe dar um poder maior que o de Perón, retroage a uma época que não é a sua. Parecendo desconhecer os novos ares trazidos pelo maio de 1968, e a militância GL do mesmo período, o autor recupera o imaginário e o vocabulário da caserna e do clero contemporâneos ao golpe que derrubou Perón, a ironicamente denominada "revolução libertadora".

Por seu turno, as personagens de Evita vive (1975), El cadáver (1980), Joyas macabras (1983) e El cadáver de la nación (1989), elaboradas entre os anos mais sangrentos do autoritário Processo de Reorganización Nacional e a reestruturação pós-ditatorial, fazem notar a passagem do tempo numa espécie bem platina de nostalgia, a enxergar no "isso foi" do nascente movimento gay argentino uma esperançosa ligação entre homossexualidade e politica que agora se esvai em meio "ao isso nunca mais será o mesmo", no qual ressaltam a cooptação das subjetividades desviantes, o aliancismo partidário, a heteronormatividade dos meios de comunicação e os apelos do mercado de consumo. Não era mesmo aos casais homotelevisivos chancelados pela grande midia globalizante, mas aos "viados" de todos os paraísos perdidos que Martínez assim se referia: "Elas a possuem, a apalpam, se entregam a ela. Mas afinal de contas, não foi isso que Evita pediu que o povo fizesse com sua memória?” (p. 175).

tíbulo, sua negativa de aderência ao protocolo consagrado" (FOSTER, 1999, p. 531 - tradução nossa). 


\section{REFERÊNCIAS}

ARFUCH, Leonor. O espaço biográfico: dilemas da subjetividade contemporânea. Tradução de Paloma Vidal. Rio de Janeiro: EdUERJ, 2010.

BARTHES, Roland. Câmara clara. Tradução de Júlio Castañon Guimarães. Rio de Janeiro: Nova Fronteira, 1984.

- Sade, Fourier, Loyola. Tradução de Mário Laranjeira. São Paulo: Brasiliense, 1990. BETTELHEIM, B. A psicanálise dos contos de fadas. Tradução de Arlene Caetano. Rio de Janeiro: Paz e Terra, 1980.

BROOKS, Peter. The melodramatic imagination: Balzac, Henry James, melodrama and the mode of excess. London: Yale University Press, 1976. (With a new preface).

BURGOS, Nidia. Los textos literarios sobre Eva Perón. Apropiaciones, representaciones y desplazamientos del imaginario popular. Imaginario, São Paulo, v. 13, n. 14, p. 1, jun. 2007. Disponivel em: <http://pepsic.bvsalud. org/scielo.php?script=sci_arttext\&pid=S1413$666 \times 2007000100005 \& 1 \mathrm{ng}=\mathrm{pt} \& \mathrm{nr} \mathrm{m}=$ iso $>$. Acesso em: 26 dez. 2013.

DOSSE, François. La apuesta biográfica: escribir una vida. Valencia: EdUV, 2007. 
ERIBON, Didier. Identidades: reflexiones sobre la cuestión gay. Tradução de José Miguel Marcén. Barcelona: Bellaterra, 2000.

FOSTER, David William. Evita, Juan José Sebreli y género. Revista Canadiense de Estudios Hispánicos (RCEH), Edmond, ..., ..., ..., v. 23, n. 3, p. 529-537, Spring; 23 mar. 1999.

GOLDAR, Ernesto. E1 peronismo en la literatura argentina. Buenos Aires: Freeland, 1971.

JAUMANDREU, Paco. La cabeza contra el sue1o: memorias. Buenos Aires: Corregidor, 1981.

. Evita fuera del balcón. Buenos Aires: Ediciones del Libro Abierto, 1981.

LAMBORGHINI, Osvaldo. El fiord. Buenos Aires: Chinatown, 1969.

MARTÍnEZ, Tomás Eloy. Santa Evita. Buenos Aires: Planeta, 1995.

MARTÍNEZ, Tomás Eloy. Santa Evita. Tradução de Sergio Molina. São Paulo: Companhia das Letras, 1996.

MELO, Adrián. E1 amor de los muchachos: homosexualidad \& literatura. Buenos Aires: Lea, 2005.

ORTIZ, Alicia Dujovne. Eva Perón: la biografia. Buenos Aires: Aguilar, 1995. 
PERLONGHER, Néstor. Evita vive (1975). E1 cadáver (1980). Joyas macabras (1983). El cadáver de la nación (1989). In: PERLONGHER, Néstor. Prosa plebeya. Buenos Aires: Colihue, 2008. (Selección y prólogo de Christian Ferrer y Osvaldo Balgorria).

PUIG, Manuel. La tajada. In: AMÍCOLA, José (Ed.). Materiales iniciales para 'La traición de Rita Hayworth'. La Plata: Centro de Estudios de Teoría y Crítica Literaria: Universidad Nacional de La Plata, 1966.

RICE, Tim. Don't cry for me Argentina.

In:_ Evita (Songbook). [London?]: Hal

Leonard, p1997. 1 CD (ca. 60 min), faixa 18.

ROSANO, Susana. Rostros y máscaras de Eva Perón: imaginario populista y representación (Argentina, 1951-2003). 2012. Tese (Doutorado em Filosofia) - University of Pittsburgh, Pittsburg, 2005.

SARLO, Beatriz. Una modernidad periférica. Buenos Aires, 1920-1930. Buenos Aires: Nueva Visión, 1988.

SARLO, Beatriz. A paixão e a exceção: Borges, Eva Perón, Montoneros. São Paulo: Companhia das Letras; Belo Horizonte: EdUFMG, 2005. SEBRELI, Juan José. Eva Perón, ¿aventurera o militante? Buenos Aires: Editorial Siglo XX, 1966. 
SONTAG, Susan. Camp - algumas notas. In: Contra a interpretação e outros ensaios. Lisboa: Gótica, 2004.

SOUZA, Eneida Maria de. Crítica cult. Belo Horizonte: EdUFMG, 2002.

SUSTI GONZÁLEZ, Alejandro. "Seré millones": Eva Perón: melodrama, cuerpo y simulacro. Rosario: Beatriz Viterbo Editora, 2007.

TABORDA, Raúl Natali Roque Damonte Botana (Copi). Eva Perón. Tradução de Jorge de Monteleone. Buenos Aires: Adriana Hidalgo, 2000.

WALSH, María Elena. Eva. In: . Canciones contra el mal de ojo. Buenos Aires: Sudamericana, 1976. 


\section{DIALOGISMO ENTRE TEXTOS BÍBLICOS E POEMAS DE VALDO MOTTA NA CONSTRUÇÃO DO TEMA HOMOERÓTICO}

Carlos Eduardo Albuquerque Fernandes ${ }^{1}$

\section{Questões introdutórias}

A relação entre o homoerotismo e as práticas discursivas sobre o "sagrado" na religião cristã quase sempre foi pontos de conflito, haja vista o caráter pecaminoso que era (é), do ponto de vista bíblico, um homem que se deita com outro homem como se fosse mulher, conforme lemos nas leis mosaicas expressas no livro de Levítico 20:13: "Se também um homem se deitar com outro homem, como se fosse mulher, ambos praticaram coisa abominável; serão mortos; o seu sangue cairá sobre eles".

Graças à tradição exegética, os sujeitos que praticaram "coisa abominável" foram silenciados ao longo da história e, consequentemente, a recepção da temática homoafetiva no texto literário também causou muitos conflitos. Quando Bom Crioulo - romance brasileiro a abordar o amor entre dois homens, em 1895 -,

1 Professor da Universidade Federal Rural de Pernambuco; doutorando em Letras pela Universidade Federal da Paraíba. E-mail: <eduardo-af-@hotmail.com>. 
de Adolfo Caminha, foi recebido pela sociedade, causando escândalo e, ainda que permeado pelos julgamentos decadentistas do naturalismo, a relação entre Amaro e Aleixo provocou os críticos e atrapalhou a recepção do livro. No mesmo ano da publicação de Bom Crioulo, Oscar Wilde, famoso dramaturgo inglês, autor do romance de temática gay, $O$ retrato de Dorian Gray, foi condenado a dois anos de prisão com trabalhos forçados sob a acusação de praticar sodomia (FRY; MACRAE, 1983).

O termo "sodomia", que possui origem na tradição bíblica, nos remete à narrativa sobre a cidade de Sodoma, para onde o personagem Ló se dirigiu ao separar-se do tio Abrão. O narrador do Gênesis afirma que os habitantes de Sodoma "eram maus e grandes pecadores contra o Senhor" (Gênesis 13:13) e por causa de seus pecados, a cidade foi destruída (Gênesis 19), demonstrando a insatisfação divina com as ações dos sodomitas, que eram as práticas sexuais não destinadas à procriação (o coito anal, o coito com animais), e dentre elas, práticas sexuais entre homens de maneira condenável.

Assim, também, a literatura que aborda a temática homoerótica tem assumido o posto delegado pelo discurso teológico sobre as relações afetivo-sexuais entre pessoas do mesmo sexo; tendo sido rotulada de literatura maldita, tornou-se pouco lida, estudada e publicada, haja vista as barreiras canônicas e exegéticas em se permitir um diálogo aberto sobre esse tema. 
Um episódio importante envolvendo literatura, homoerotismo e religião, ocorreu em 1923, quando os escritores portugueses António Botto e Raul Leal escreveram obras que tornavam visivel o desejo sexual entre pessoas do mesmo sexo em personagens e sujeitos poéticos; a atitude dos escritores foi nomeada de "literatura de Sodoma", e um grupo de estudantes de cunho católico reagiu contra as publicações:

Daí em diante, seguem-se notícias de perseguição e censura aos livreiros, culminando com uma ação violenta dos estudantes sobre livrarias que expunham e vendiam obras de Botto e de Leal e com a proibição por parte do governo civil de Lisboa da exposição e venda de tais obras em março de 1923, instalando uma censura oficial que não era praticada desde os tempos da Revolução Constitucionalista de 1820 (LUGARINHO, 2003, p.139).

O motivo religioso, nesse episódio da história de Portugal, foi o agravante para o rechaço da literatura de temática homoerótica, bem como o de seus escritores. A religião sempre exerceu forte influência na cultura das sociedades ocidentais em suas práticas discursivas e sexuais, como nos confirmam Magalhães e Silva (2008, p.160-161):

A religião encontrou distintas formas de lidar com os corpos, de interpretá -los e incluí-los em sua vasta simbo- 
logia. Não é conhecida uma religião, no mundo, que não tenha construído uma ética do corpo e da sexualidade. [...] A vigilância e o controle dos corpos, a divisão radical entre papéis do homem e da mulher são expressões destas relações, não as únicas.

Em contraponto a essa tradição de controle dos corpos, as questões de gênero e de sexualidade voltadas para as minorias culturais vêm ocupando um espaço de discussão cada vez maior e relevante nas sociedades ocidentais. Devido às transformações culturais pelas quais passam as sociedades na modernidade tardia ou na pós-modernidade (nomenclaturas utilizadas por Hall, 1997), fragmentam-se as paisagens culturais de classe, gênero, sexualidade, etnia, dentre outras categorias que, em meio à globalização, através do encontro e de mistura entre as culturas, e das rupturas do conhecimento moderno, caracterizam o contexto cultural em que novas maneiras de perceber as diferenças se apresentam viáveis e necessárias.

Nossa discussão se centra, portanto, na abordagem de dois temas que parecem trilhar caminhos opostos nas práticas discursivas: religião e homoerotismo, uma vez que a primeira insiste em "controlar os corpos", como afirmam Magalhães e Silva (2008); e o segundo encena-se numa atividade de construção e desconstrução de normas, "como transgressão social, demolição das barreiras entre classes, portanto libertação do indivíduo" (FERNANDEZ citado por BARCELLOS, 2006, p. 135). 
Chama-nos atenção, no entanto, o fato de a literatura aproximar os dois temas, estruturando-se o desejo homoerótico expresso por sujeitos poéticos e por personagens de ficção através do diálogo com imagens, personagens e símbolos de textos bíblicos, considerados sagrados pelo discurso teológico, o que nos incita a perguntar: que implicação pode haver na representação do homoerotismo através do dialogismo com o texto bíblico? Diante dessa questão, nosso objetivo é investigar as relações dialógicas entre a literatura de temática homoerótica e textos bíblicos, buscando analisar em que medida essas relações contribuem para uma perspectiva de maior abertura às relações homoafetivas do ponto de vista cultural. Tomamos como corpus de análise o livro de poemas Bundo e outros poemas (1996), de Valdo Motta, para assim tentar discutir a presença do discurso considerado sagrado na literatura de temática homoerótica².

É importante destacarmos algumas noções importantes a respeito das bases teóricocriticas sobre as quais pretendemos discutir os textos literários em questão. Partimos do princípio bakhtiniano de que, do ponto de vista do funcionamento da linguagem, "todos os

2 Empregamos a expressão Literatura de temática homoerótica a partir de Silva (2007) e Lugarinho (2008), que a usam para se referir às obras literárias que centralizam o tema das relações entre pessoas do mesmo sexo. Podemos citar algumas obras literárias de temática homoerótica que dialogam com textos bíblicos: o conto homônimo de Testamento de Jônatas deixado a David (1976), de João Silvério Trevisan; alguns poemas de Ciclones (1997), de Roberto Piva; e alguns contos de Eis o mistério da Fé (2009), de Antonio de Pádua Dias da Silva. 
enunciados constituem-se através de outros" (FIORIN, 2006, p. 30). E, portanto, as relações dialógicas nos textos literários são recorrentes entre diversos temas e textos formando uma rede através da qual podemos ver, por meio de uma leitura atenta, os entrelaçamentos textuais e ideológicos.

Assim, entendemos que a literatura de temática homoerótica pode estabelecer relação dialógica com textos, discursos bíblicos/ sagrados. Preferimos adotar a denominação bakhtiniana de dialogismo por esta parecer mais abrangente do que a intertextualidade e interdiscursividade (haja vista também a especificidade que cada uma dessas categorias possui para diferentes autores), uma vez que diz respeito desde a própria constituição do ser humano (MORSON; EMERSON, 2008) até as relações de elementos estruturais e alusões ideológicas que podem haver nos textos.

Para além das nossas impressões sobre as relações dialógicas entre o sagrado e a literatura, concordamos com Eliade (1989, citado por SILVA, 2004, p. 55) quando afirma que a experiência com o sagrado

[...] faz parte de um conjunto de experiências humanas mais profundas que, antes de serem trazidas à linguagem verbal, ficam codificadas no interior do ser humano formando uma complexa rede, uma espécie de fundo simbólico.

E, assim, a literatura, independente do gênero literário ou tema no qual se centra, 
parece estar tomada desse "fundo simbólico", lançando mão de metáforas, alusões, ou mesmo através da transcrição de textos considerados sagrados, dependendo da cultura. Resta, então, discutir os poemas escolhidos e argumentar sobre esse curioso dialogismo entre a poética de Valdo Motta e a Bíblia.

\section{"O vosso corpo é santuário do Espírito Santo" (I Corintios 6: 19)}

A obra Bundo e outros poemas (1996), do escritor capixaba Valdo Motta ${ }^{3}$, é marcada por uma escrita que aproxima, de forma transgressora, religião e homoerotismo. Essa característica faz parte de um projeto literário do autor que, no prefácio de Bundo, deixa evidente a intenção de aproximar o sagrado do erótico:

Há um desenvolvimento gradativo do tema axial, que é Deus [...] Tal dinâmica não foi premeditada, tornou-se imperativa enquanto elaborava os poemas em momentos regidos por marés secretas. Sempre reconsiderei certos aspectos de minha cosmovisão homoerótica e certas percepções dos significados do corpo-templo e seus membros vibráteis, cheios da presença de Deus [...] (MOTTA, 1996, p. 8).

3 Atualmente, o autor grafa o próprio nome com inicial "W" ao invés de "V" por questões numerológicas; no entanto, optamos por nos referir ao nome dele conforme está grafado na obra em discussão. 
Pelo fragmento, fica claro que um dos temas principais dos poemas do autor é Deus, em suas mais variadas manifestações. Se o corpo é templo do Espírito Santo, a poesia de Valdo Motta vai explorá-lo como manifestação do sagrado, fazendo referência ao baixo corporal, o que possivelmente causa estranhamento ao leitor, ao entrar em contato com sua obra, como o poeta admite em depoimento divulgado por Vieira Jr. (2010, p. 1):

Sempre fui considerado um poeta indecente, obsceno. Isto porque eu sempre misturei baixo calão com alto calão. O mais chocante de tudo é que [...] quanto mais eu procuro Deus, o sagrado, eu sempre acabo chegando aos 'países baixos', a uma geografia muito interessante do corpo humano. [...] Desde o início da história humana, existem tabus. E o que eu descobri nas minhas pesquisas e que reflete na minha poesia, é que a sexualidade é tanto a perdição quanto a salvação da humanidade (grifo do autor).

Por essas afirmações, já podemos perceber que a poesia de Bundo (1996) irá construir uma ligação entre polos aparentemente opostos. O termo principal do título do livro, segundo Simon (1998, p. 173), "significa indivíduo do povo africano Bundo, língua de negro, língua errada, maneira errada de falar e ser, coisa ruim, coisa ordinária" ou ainda seria, como o poeta afirma, o marido da bunda. É nessa linha de entrelaçamento do profano e do 
sagrado que os poemas estabelecem relação dialógica com a Bíblia, à medida que retomam figuras e imagens dos textos bíblicos: as referências a montes sagrados, Deus, vara, rochedo sempre irão metaforizar partes do corpo.

As nádegas e o ânus são as partes do corpo mais "sacralizadas" nos poemas, o sujeito poético as exalta e as deseja, como lemos no poema "Exortação":

Venerai o Santo Fiofó,/ ó neófito das delícias, / e os deuses hão de vos abrir as portas/ das inúmeras moradas do Senhor/ e a fortuna vos sorrirá/ com todos os encantos e prodígios (MOTTA, 1996, p. 32).

Veja-se, no poema, que o ânus referido como "Santo Fiofó" é grafado com letra maiúscula, demonstrando um respeito pela parte do corpo tida, no texto, como sagrada; o título do poema já remete à sua mensagem: exortar é incentivar, dar estímulo, e os verbos empregados no modo imperativo nos remetem aos discursos religiosos em que o "neófito" - sujeito que acabou de ou vai ser batizado - ouve recomendações de como agir para que as portas das moradas do Senhor sejam abertas. O "neófito das delícias" deve, portanto, venerar o ânus para alcançar os "encantos e prodígios".

O emprego lexical aproxima o poema da linguagem bíblica, o vocativo "ó neófito" e as palavras do verso "e os deuses hão de vos abrir as portas" são facilmente encontradas em versículos bíblicos. A forma verbal 'hão', o 
pronome pessoal oblíquo 'vos' nos fazem lembrar a linguagem do discurso dos Salmos, a saber, no Salmo 22:29, lemos "Todos os opulentos da terra hão de comer e adorar [...]", também no Salmo 96:9: “Adorai o Senhor na beleza da sua santidade; tremei diante dele, todas as terras". Veja-se que as formas verbais ("hão", "adorai", "tremei") são semelhantes nos versículos e no poema. A maioria dos textos de Bundo (1996) é construida através dessa linguagem que incorpora estruturas sintáticas usadas na Bíblia: o tom sacro, de respeito e de subserviência, configurado a partir da seleção lexical, das estruturas sintáticas, do emprego de formas verbais comuns nos textos bíblicos.

É recorrente nos poemas a alusão a montes relacionados à bunda:

Ó mãos abençoadas, que sondais/ os montes gêmeos;/ falanges sagradas, que recreais/ na toca da serpente./ Nações do mundo inteiro,/ eis o meu canto:/ é tempo de alegria, de brincar/ no monte santo (MOTTA, 1996, p. 27).

As curvas das nádegas são inscritas no poema como as curvas de montes gêmeos, o sujeito poético define esses montes (que curiosamente são também a "toca da serpente") como santos, sagrados. Na Bíblia, há diversas menções a montes que serviam de local de encontro com Deus, como exemplo se pode mencionar que Moisés recebeu as tábuas da lei no alto do Monte Sinai e Elias obteve o milagre da chuva após ter orado no 
alto do Monte Carmelo, dentre muitas outras referências.

Segundo Chevalier e Gheerbrant (2002), os montes/montanhas, por sua verticalidade, possuem uma simbologia voltada para a ascensão, estabelecendo uma conexão com o alto. No poema em questão, os montes gêmeos que aludem às nádegas parecem ter essa conotação de local sagrado, local de encontro, de conexão com Deus. Devemos apontar que as estratégias recorrentes de alusões ao sagrado para expressão do desejo homoerótico, nos poemas de Valdo Motta, remetem à carnavalização que atualiza visões sob outras perspectivas; observamos que o sagrado, comumente interpretado como sentimento gestado e direcionado para o alto, daí as imagens que se referem a montes (elevação), Deus (no alto), vara (para cima), rochedo (forte, protuberante) são subvertidas, ao passo que a ligação com o homoerótico se dá na posição contrária: com o baixo corporal: as nádegas, o pênis. A carnavalização se dá justamente quando esses símbolos são convertidos de sua relação do alto para o baixo, do espiritual para o corporal.

Essa conotação dos montes como parte do corpo do homem que se conecta ao divino pode ser lida na maioria dos poemas, como em "Encantamento":

Ó Deus serpentecostal que habitais os montes gêmeos e fizeste do meu cu o trono do vosso reino, santo, santo, santo espírito 


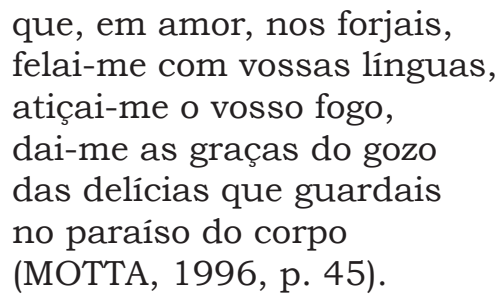

Acreditamos que, nesse poema, podemos perceber alguns aspectos recorrentes nos textos de Valdo Motta: a linguagem subversiva, o emprego de termos que rompem o véu da moralidade e do discurso teológico. O texto é construído como uma oração em que o sujeito poético inicialmente invoca o divino que é adjetivado com o neologismo "serpentecostal" e, ao dissecá-lo, nos deparamos com a visualização de, pelo menos, duas expressões: "ser pentecostal" e "serpente costal". Detendo-nos nesta, o adjetivo "costal" significa dorsal ou das costas, assim, seria uma serpente das costas ou que vive às costas do indivíduo; a serpente na Bíblia é, na maioria das vezes, associada ao pecado e a Satanás, um animal maldito, mas, conforme Chevalier e Gheerbrant (2002), também simboliza a fertilidade e o falo. Dessa maneira, a invocação ao Deus já demonstra uma perspectiva transgressora.

O sujeito poético afirma que Deus habita nos montes gêmeos (alusão às nádegas, como já mencionamos) e fez de seu "cu" o reino dele; como nos demais poemas discutidos, os sujeitos poéticos afirmam que o ânus é a morada do divino. Após a invocação, o sujeito passa a uma petição: pede a Deus que lhe conceda 
prazeres sexuais. A forma verbal no imperativo "felai-me" é um neologismo comum à oralidade e diz respeito à penetração, ao intercurso sexual que o eu poético deseja ter com as línguas do Deus. Dessa forma, o poema se apresenta com uma linguagem que constrói uma dessacralização da figura divina, uma vez que denomina o local sujo ${ }^{4}$, o canal expelidor de excremento do corpo humano, como local sagrado, como morada do que é considerado absolutamente puro, santificado; mais uma vez, vemos a mescla do alto (sagrado) com o baixo corporal (profano), do puro com o impuro, do espírito com a carne.

A configuração, no poema "Encantamento", de Deus como uma serpente ou falo que está às costas do indivíduo, nos remete a outro poema: "Deus atrás de todo mundo./ Deus fiel e bão, que atiça/ o fogo da vida em nosso rabo" (MOTTA, 1996, p. 30). Em ambos os poemas, o sujeito poético deseja a cópula com Deus. Detendo-nos em outra interpretação, o termo "serpentecostal" como 'ser pentecostal' nos remete ao episódio do dia de Pentecostes, narrado no livro de Atos, em que os apóstolos pregaram para pessoas oriundas de diferentes nações que entenderam a mensagem pregada, cada um em sua língua, apesar de os discípulos não dominarem o falar dos outros povos, o que ficou conhecido como o "dom de línguas".

\footnotetext{
4 Empiricamente, denomina-se o ânus de "local sujo", por ser o canal de expulsão das fezes, dejetos do corpo. No entanto, para o homoerotismo masculino, o ânus é de fundamental importância para a realização sexual e assume, de fato, também a função de órgão sexual.
} 
No poema, os versos "felai-me com vossas linguas/ atiçai-me o vosso fogo" (MOTTA, 1996, p. 45) nos lembra a passagem de Atos $2: 3$ e $4:$

E apareceram entre eles, linguas como de fogo, e pousou uma sobre cada um deles. Todos ficaram cheios do Espírito Santo e passaram a falar em outras línguas, segundo o Espírito lhes concedia que falassem.

Observamos que os termos língua, fogo e a palavra felar, como corruptela de falar, aproximam os dois textos. O eu lírico adapta o fogo que desceu sobre os apóstolos no dia de Pentecostes em fogo, como empregado no dizer popular, do tesão sexual, penetrado pelas linguas, remetendo ao ato sexual denominado de cunilíngus, gíria que, segundo Vip e Lib (2007), designa o sexo oral na região do ânus. Ora, se a bunda é o reino, a língua falada nele é estranha (o que nos remete ao universo Pentecostal): línguas de fogo, de felação que permitem a cópula com o divino.

Trevisan (2002), ao discorrer a respeito das práticas do shivaísmo (religião nascida na Índia, em 6000 a.C.) e sua influência sobre a cultura ocidental, afirma que é através da vivência erótica que se chega à raiz do ser humano, e a experiência sexual seria o caminho mais direto para o divino:

Exercitar a sensualidade é, portanto, encontrar-se com Deus através do 
êxtase presente no orgasmo, que permite ao ser humano romper as barreiras do racional e atingir um nivel de profundidade pessoal muito além do pensamento lógico (TREVISAN, 2002, p. 256).

Os poemas de Valdo Motta parecem explicitar esse desejo de contato profundo com o divino, com o sagrado, aproximando, de tal forma, criatura e criador que eles passam a ser apenas um através da cópula anal, haja vista que Deus sempre está atrás dos sujeitos poéticos e habita nos "montes gêmeos [ou no] Santo Fiofó [ou nos] montes rebolantes" (MOTTA, 1996, p. 42).

Passagens bíblicas que estão compiladas no livro de poemas também demonstram essa característica da relação do eu poético com o divino: Em primeiro lugar, de que Deus sempre está à traseira dos indivíduos:

(a) [...] os teus ouvidos ouvirão atrás de ti uma palavra, dizendo: Este é o caminho, andai por ele (Isaías 30: 21);

(b) $[\ldots]$ ouvi por detrás de mim uma voz de grande estrondo, que [...] dizia: Bendita seja a glória do Senhor (Ezequiel 3:12);

(c) Achei-me em espírito, no dia do Senhor, e ouvi, por detrás de mim, grande voz, como de trombeta (Apocalipse 1:10).

É interessante observarmos que, nessas três passagens de livros proféticos, a voz do 
Senhor fala aos profetas sempre por trás deles, às costas dos personagens; evidentemente, essa é uma possibilidade interpretativa das narrações de Isaías, Ezequiel e João, entretanto, a postura divina nos poemas de Valdo Motta, que discutimos brevemente, parece ter um respaldo nas experiências dos profetas.

Em segundo lugar, Deus habita no centro, no mais íntimo de cada individuo:

(d) $[\ldots]$ o Senhor, teu Deus, está no meio de ti (Deuteronômio 7:21);

(e) [...] tu, ó Senhor, estás no meio deste povo [...] (Números 14:14);

(f) $[\ldots]$ o reino de Deus está dentro de vós (Lucas 17:21).

Nessas passagens, fica claro que a presença de Deus se faz no íntimo do ser humano, no meio do povo. Nos poemas discutidos, o centro é configurado como o ânus, o meio do corpo. Lembremos que essa parte do corpo é metaforizada como montes santos, 1ocais que remetem ao encontro com o divino, na Bíblia.

Além disso, nas culturas xamânicas e hindu, conforme Chevalier e Gheerbrant (2002), o homem possui chakras que são pontos ocultos no corpo humano por onde circulam a energia vital e flui a comunicação com o divino. O mais importante desses pontos, para essas religiões, é o chakra de base, responsável pela sobrevivência e poder pessoal, localizado na região do períneo, e nos reme- 
te à localização corporal de manifestação do sagrado nos poemas de Valdo Motta, isto é, a região anal.

Ainda podemos argumentar que os poemas ora comentados constroem o que Bakhtin denominou de carnavalização e, conforme Morson e Emerson (2008), caracteriza-se pela inversão de valores, pela subversão, por uma atitude de dessacralização. Uma das estratégias da carnavalização no texto literário é a referência ao baixo-corporal, empregando uma linguagem que rompe com padrões morais e religiosos. Em Bundo (1996), podemos visualizar a carnavalização da visão cristã sobre a religião, sobre o divino e a sexualidade. Os poemas conseguem subverter esses conceitos, quando estabelecem relação dialógica com o texto bíblico, lançando mão de novas significações para estes. Com efeito, a alusão à cópula com o divino, a conversão dos montes santos nas nádegas masculinas dessacralizam a perspectiva cristã a respeito da relação entre o corpo e a religião; se, no versículo de I Corintios 6:19, o corpo é templo abstrato do Espírito Santo, nos poemas de Valdo, tornase "templo" concreto onde Deus pode entrar e provocar prazeres inefáveis. 


\section{REFERÊNCIAS}

BARCELLOS, José Carlos. Literatura e homoerotismo em questão. Rio de Janeiro: Dialogarts, 2006.

BERGAÇO, Ériton. B. Bundo, o erotismo sagrado da bunda: a construção poética de Waldo Motta em Bundo e outros poemas. In: LOPES, Denílson et al. (Org.) Imagem e diversidade sexual - estudos da homocultura. São Paulo: Nojosa Edições, 2004.

BÍBLIA. Português. Bíblia Sagrada: Antigo e Novo Testamento. Tradução de João Ferreira de Almeida. 2. ed. rev. e atual. Barueri: Sociedade Bíblica do Brasil, 1993.

CHEVALIER, Jean; GHEEBRANT, Alain. Dicionário de simbolos: (mitos, sonhos, costumes, gestos, formas, figures, cores, números). Tradução de Vera da Costa e Silva et al. 17. ed. Rio de Janeiro: José Olympio, 2002.

FIORIN, José Luiz. Introdução ao pensamento de Bakhtin. São Paulo: Ática, 2006.

FRY, Peter; MACRAE, Edward. O que é homossexualidade? 2. ed. São Paulo: Brasiliense, 1983.

HALL, Stuart. A identidade cultural na pósmodernidade. Tradução de Tomaz Tadeu da Silva; Guacira Lopes Louro. Rio de Janeiro: DP\&A, 1997. 
LUGARINHO, Mário César. Literatura de Sodoma: o canône literário e a identidade homossexual. Revista Gragoatá, Niterói, v. 14, p. 133-147, $1^{\circ}$ sem. 2003.

. Nasce a literatura gay no Brasil: reflexões para Luís Capucho. In: SILVA, Antonio de Pádua Dias da (Org.). Aspectos da literatura gay. João Pessoa: Editora Universitária da UFPB, 2008.

MAGALHÃES, Antonio Carlos de Melo; SILVA, Eli Brandão da. Religião, sexualidade e representação de gênero: considerações introdutórias. In: SILVA, Antonio de Pádua Dias da (Org.). Identidades de gênero e práticas discursivas. Campina Grande: Editora Universitária; UEPB, 2008.

MORSON, Gary Saul; EMERSON, Caryl. Mikhail Bakhtin: criação de uma prosaística. Trad. Antonio de Pádua Danesi. São Paulo: EdUSP, 2008.

MOTTA, Valdo. Bundo e outros poemas. Campinas: Editora da UNICAMP, 1996.

SILVA, Antonio de Pádua Dias da. Considerações sobre uma literatura gay. In: SILVA, P. D. da; ALMEIDA, M. L. L.; ARANHA, S. D. G. (Org.). Literatura e linguistica - teoria, análise e prática. João Pessoa: Editora Universitária da UFPB, 2007. 
SILVA, Eli Brandão da. O símbolo na metáfora : fronteira entre o literário e o teológico. In. SILVA, Antonio de Pádua Dias da (Org.) Literatura e estudos culturais. João Pessoa: Editora Universitária da UFPB, 2004.

SIMON, Iumna Maria. Sobre a poesia de Valdo Motta. revistausp, São Paulo, v. 36, p. 172177, dez.-jan.-fev. 1997-1998. (Entrevista).

TREVISAN, João Silvério. As formas bizarras do sagrado. In: _. Pedaço de mim. Rio de Janeiro: Record, 2002.

VIEIRA JR, Erly. A desbundada poesia erótico-mistica de Waldo Motta. [S.1.; [21--]]. Disponivel em: <http: / /www.overmundo.com.br/ overblog/a-desbundada-poesia-erotico-mistica-de-waldo-motta>. Acesso em: 26 jul. 2010.

VIP, Angelo; LIBI, Fred. Aurélia, a dicionária da lingua afiada. São Paulo: Editora da Bispa, 2007. 


\section{"CORDELISANDO" A TEORIA QUEER: UMA ANÁLISE DAS PERSONAGENS TRAVESTIS NOS CORDÉIS}

Francisco Leandro de Assis Neto ${ }^{1}$

\section{Considerações iniciais}

Tratar de questões relacionadas à sexualidade humana, desde o século XIX, vem se revelando um trabalho de mapeamento das vontades e instintos, em muitos casos. O discurso cientificista oriundo deste periodo tentou, por diversas vezes, desvendar a natureza humana, marginalizando práticas e sujeitos que se desviassem da norma. Termos como "heterossexual" e "homossexual" foram cunhados em datas da segunda metade do século XIX (KATZ, 1996). O sujeito entra em cena, passa a ser estudado, não somente por suas práticas, mas pela motivação psíquica que as envolvia.

Poderíamos perceber aí o embrião das chamadas identidades sexuais e/ou de gênero, definições e argumentações acerca dos sujeitos e práticas, que seriam reelaboradas e questionadas somente a partir da segunda

1 Mestre em Literatura e Interculturalidades, Universidade Estadual da Paraíba; doutorando em Literatura e Interculturalidades, Universidade Estadual da Paraíba.

E-mail: <leandroassis.uepb@gmail.com>. 
metade do século XX, motivado pelos movimentos das chamadas minorias, como o feminismo, o ativismo negro nos Estados Unidos, as lutas do proletariado, as lutas contra as ditaduras na América Latina etc., eclodidos durante a década de 1960. O discurso contestador sobre a naturalização dos sujeitos e a "patologização" destes surge. Importantes pensadores como Michel Foucault, Gilles Deleuze, Felix Guattari, Jacques Derrida, contestaram e repensaram a lógica estruturalista - em grande parte fundamentada nos escritos de Ferdinand de Saussure.

A solidez dos discursos das esferas de saber oficiais (jurídico, religioso, médico) é questionada, à medida que os sujeitos marginalizados começam a produzir seus discursos. A dicotomia entre verdadeiro/falso é questionada nos discursos fundantes, como nos mostra Foucault (1979, p. 7):

Há um combate 'pela verdade' ou, ao menos, em torno da verdade - entendendo-se, mais uma vez, que por verdade não quero dizer 'o conjunto das coisas verdadeiras a descobrir ou fazer aceitar', mas 'o conjunto de regras segundo as quais se distingue o verdadeiro do falso e se atribui ao verdadeiro efeitos específicos de poder'; também que não se trata de um combate 'em favor' da verdade, mas em torno do estatuto da verdade e do papel econômico-político que ela desempenha. 
Assim percebemos que, nas tramas dos discursos sociais, bem como nas suas redes de poder, existe o redimensionamento do sujeito, o deslocamento de imagens concebidas secularmente e questionadas. Esse questionamento pode produzir toda a formulação de uma rede de antidisciplina, propiciada pelas plurais leituras que podem ser feitas do jogo de relações poder/saber e da vivência cotidiana com várias modalidades discursivas de historicidade, pertencimento cultural, institucional e etc.; de autores e leitores desse cotidiano que, influenciados pela cultura e pelo momento histórico, podem reproduzir ou (re)inventar verdades, sujeitos e práticas.

Neste estudo, nos utilizaremos de obras da literatura de cordel para a análise das representações das personagens travestis nas obras: A briga de um gay com uma mulher macho (MONTEIRO, 2009), O garanhão que lascou-se com um travesti (CAMPOS FILHO, s/d), $O$ padre que virou mulher (MENEZES, 1988). Apontaremos que, no interior de uma produção discursiva tida, durante muito tempo, como representante de uma cultura tradicional, patriarcal e falocêntrica, de uma região historicamente masculinista e sexista - o Nordeste brasileiro - outras possibilidades de representação do sujeito travesti e de suas práticas podem ser concebidas, contrariando aspectos do préconstruido (PECCHEUX, 2009). Sabendo que o enunciado não se realiza exclusivamente na órbita da linguística, tampouco na da física, mas, em relação estrutural que mescla o imagético 
e o linguístico, trataremos a irregularidade do corpo e das práticas dos travestis discursivizados nos cordéis, sob a perspectiva da teoria queer. Assim, ao analisarmos tais séries enunciativas, constataremos que a teoria queer, que visa à pluralidade performativa dentro da própria diversidade, pode ser aplicada a um discurso que, sob o olhar desatento, pode apenas sugerir uma representação social preconceituosa e degradante do travesti.

\section{Aspectos teóricos-metodológicos da teoria queer}

Práticas disciplinadoras do desejo humano - desejo na forma do exercício da sexualidade, de transbordar o "lícito" - desde os séculos XIII e XIX, particularmente, vêm se revelando, ao longo da história, uma prática relativamente eficaz de dominação do sujeito. A dominação, neste caso, visava ao adestramento do corpo, desejos (mesmo que sublimados) e práticas sexuais dos indivíduos, autorizado pelas instituições de poder punitivas da sociedade (o exército, a escola, o hospital, a fábrica etc.), sobretudo para a produção de um corpo dócil apto a integrar uma sociedade mecanicamente planejada pelo capitalismo que se espalhara por todo o Ocidente, neste período. A discussão da mecanização dos corpos no Ocidente, que descobrira o capitalismo, bem como a análise do discurso acerca da sexualidade, é articulada por Foucault (1988, p. 151), 
no primeiro volume de História da sexualidade, no qual coloca que

[...] no corpo como máquina, no seu adestramento, na ampliação de suas aptidões de suas forças, no crescimento paralelo de sua utilidade e docilidade, na sua integração em sistema de controle eficazes e econômicos,

o homem se integraria à lógica capitalista de maneira a reproduzir uma conduta adequada à sociedade em que nascia.

A partir da observação de todo o sistema disciplinador do sujeito, Foucault forja os termos "biopoder" e "biopolitica", dois conceitos que, mais tarde, fomentariam questionamentos levantados pela teoria queer. Contudo o biopoder e/ou biopolítica não agem de forma uniforme e genérica de fora para dentro, mas começam no interior dos corpos, falseando um discurso naturalista, requerendo a doutrinação, repetição e vigilância contínua do sujeito, a fim de maximizar sua performance social dentro do sistema capitalista. Acerca disto, Machado (2007, p. 19) aponta:

É o diagrama de um poder que não atua no exterior, mas trabalha o corpo dos homens, manipula seus elementos, produz seu comportamento, enfim, fabrica o tipo de homem necessário ao funcionamento e manutenção da sociedade industrial, capitalista. 
O biopoder, atuando no interior do homem, ainda preconizava processos como o controle da natalidade, assim manipulando o processo populacional; o controle da saúde do indivíduo, promovendo políticas de higienização; o controle do desejo, talvez o mais importante, ditando práticas como saudáveis ou patológicas, do ponto de vista da sexualidade. A esse corpo disciplinarizado, o filósofo dá o nome de "corpo espécie", que seria o corpo "adequado" à espécie humana, ao humano moderno e evoluído, excluindo todo aquele que não se enquadrasse nessa dinâmica.

A partir de estudos como os de Foucault, a naturalização, a patologização e a disciplinarização dos sujeitos e dos corpos foram sendo revistos. Apoiados pelos movimentos de minorias, principalmente as sexuais, mas não somente por estas, pensadores começaram a preencher lacunas e a fazer releituras a respeito dos estudos feministas, gays e lésbicas, da sociologia do desvio norte-americana e do pós-estruturalismo francês, surgido em meados dos anos 1980 o pensamento que, mais tarde, se traduziria em uma teoria queer.

A teoria queer surge em tempos de reavaliação crítica das políticas identitárias. O termo queer, segundo Louro (2001), pode ser tomado como: estranho, excêntrico, raro, extraordinário, abjeto, geralmente utilizado de forma pejorativa, nos Estados Unidos, para se referir ao sujeito gay. No entanto, há um processo de positivação engendrado pelos pensadores dessa teoria, que se utilizam do deboche e do escárnio 
para desestabilizar o próprio insulto produzido pela heteronormatividade. Sendo assim, o queer representaria aquele que não pretende ser tolerado dentro de uma lógica político-normativa. Sua ação transcende as politicas de inclusão; o queer se assume diferente e prima pela sua diferença.

Entretanto não somente de "radicalidades" esse pensamento é construído. A filósofa estadunidense Judith Butler aponta, dentro desta linha de raciocinio, questionamentos que iriam redimensionar as relações entre sexo e gênero já debatidas pelos estudos feministas. Esses estudos, em suma, têm o sexo como substância, ou seja, é fatídico e imutável o sujeito nascer macho ou fêmea (anatomicamente) e, a partir dessa possibilidade binária biológica se dará a construção do gênero, sendo ele um atributo pessoal (não confundir com individual), que, ao longo do processo de socialização e "culturamento" do individuo, molda suas condutas. Parafraseando Simone de Beauvoir: "A gente não nasce mulher, tornase mulher", Butler levanta uma série de questões acerca do lugar do gênero. Quem decide ou não e o porquê decide "tornar-se mulher"? Obrigatoriamente, poderíamos não estar nos referindo a um indivíduo biologicamente do sexo feminino, por exemplo.

A autora refere-se ao gênero como um fenômeno inconstante e contextual, não delimitador de um ser essencial, ou fixo, mas "um ponto relativo de convergência entre conjuntos específicos de relações, cultural e historicamente 
convergentes" (BUTLER, 2003, p. 29). Através dessa inconstância do gênero e das convergências e divergências propiciadas entre as relações históricas e culturais, ela elabora o conceito de performatividade do sujeito. Percebemos, então, a crítica ao feminismo humanístico e, por associação, aos movimentos identitários gays e lésbicas que, através das práticas político-ativistas, reivindicam uma identidade própria, tendo talvez como "efeito colateral" a fixidez identitária. Desta forma, o conceito de performatividade requer um lugar aberto às identidades fixas, no qual se possam articular plurais formas de expressão do sujeito, práticas e desejos, sem que se esteja inserido nesta ou naquela categoria.

Oposições binárias de raça, gênero, classe social, nacionalidade, religião, que estão direta ou indiretamente relacionadas com o antagonismo social da sexualidade, também são o foco da teoria queer. São fronteiras negadas ou transgredidas por indivíduos que não se enquadram e/ou não se conformam com as normas impostas pela biopolitica heteronormativa. Portanto, tornam-se sujeitos abjetos para o modelo cultural dominante, e para os lugares nos quais a própria noção de humanidade seria contestada pelo não enquadramento nos ideais naturalizantes e normativos humanos (PINO, 2007).

Não propomos aqui a fuga do binarismo, até porque esse movimento implicaria uma demanda teórica e uma observação minuciosa. No entanto, pretendemos questioná-la, ao nos utilizarmos de personagens que, por meio da 
prática da sua sexualidade, põem em evidência as fissuras no pensamento naturalista binário, como também desestabilizam as correlações entre sexo/gênero/desejo, através das possibilidades apresentadas pelas personagens à identidade do travesti. Tomaremos a noção posta por Butler para orientar nossa análise:

[...] abjeto para mim não se restringe de modo algum a sexo e heteronormatividade. Relaciona-se a todo o tipo de corpos cujas vidas não são consideradas vidas e cuja materialidade é entendida como não importante (BUTLER apud PRINS; MEYER, 2002, p. 161).

É a partir da rejeição do fundacionismo biológico proposto pela teoria queer que guiaremos as análises feitas, a seguir, das obras cordelísticas selecionadas, da ruptura com a ordem heterossexista e valoração daqueles que vivem às margens das normas de gênero.

\section{Um olhar queer sobre os cordéis}

Como já assinalado, nos debruçaremos sobre três obras: A briga de um gay com uma mulher macho (MONTEIRO, 2009), O garanhão que lascou-se com um travesti (CAMPOS FILHO, s/d) e O padre que virou mulher (MENEZES, 1988).

Na primeira obra, temos como personagens dois sujeitos já classificados pelo título como "gay" e "mulher macho". No entanto, 
após uma leitura mais atenta, percebemos duas personagens estigmatizadas pela elaboração do seu vestuário e pelas expressões comportamentais de gênero. Enfocaremos, contudo, a análise da representação e do discurso da personagem "gay" da obra que, por associação e pelas formas de subjetivação inscritos no cordel, podemos tê-lo como travesti. Uma vez que o narrador do episódio, por meio da descrição da personagem, traça o perfil de um sujeito facilmente reconhecido pelo senso comum como um travesti, já que, ainda que de maneira caricaturada, tenta aproximar-se do estereótipo feminino, sendo verificável nos versos: "Tinha cintura bem feita/O quadril sobressaindo/Cílios postiços e usava/Sombra batom e falava/Desmunhecando e sorrindo" (MONTEIRO, 2009, p. 4). Na segunda obra, percebemos um travesti que transcende a caricaturização do estereótipo feminino, que por meio de sua construção corpórea, da edição das marcas de gênero, confunde-se com o próprio feminino - conceituado pela perspectiva heteronormativa -, vistos nos versos:

Era um rebolado forte/Empolgante até demais/Um par de coxas bonitas/ De mini-saia e tudo mais/ Sem contar com a beleza/Parecia uma princesa de encantos naturais (CAMPOS FILHO, s/d, p. 2).

Já a terceira obra trata de um tipo particular e não muito comum de travestilidade, mais aproximada do conceito underground de 
cross-dressing, posto que a personagem - o padre - fazia uso de peças íntimas femininas e acomodava seu órgão genital de tal forma a fazer-se sentir uma mulher:

E por baixo da batina/comecei a usar vestidos/ botava corpete, blusa/ uns saiões bem compridos/uma cinta de elástico/escondia os possuídos (MENEZES, 1998, p. 5).

Os folhetins apresentam três personagens que subvertem a ordem heteronormativa e desestabilizam a performance delegada a seus corpos pelo senso comum. Essa desestabilização do próprio lugar marginal do qual as personagens do primeiro e do segundo cordel fazem parte se dá em dois movimentos. Primeiramente, no discurso do individuo presente na obra de Monteiro (2009, p. 5-7): "Sou veado /Mas sou gostosa e enxuta [...] Oras me chama cachorra/Horas me chama bem", que vai de encontro à imagem do homossexual dócil, bem educado e "domado", uma figura quase higienizada que alguns ramos do movimento LGBT tentam promover na midia. O queer, nesse caso, reflete-se justamente na postura que a personagem tem diante de si, do desejo que tem pelo seu parceiro, da submissão sexual tal qual uma "cachorra" - beirando o fetiche - ele é o "mau sujeito". Como expressa Preciado (2010, p. 66), o "Corpo queer questiona a mitologia que garante a naturalidade da filiação e da diferença sexual. Neste contexto, o mal-sujeito gera todo 
um conjunto de angústias sexuais e políticas". Neste ponto, a personagem, assim como sua conduta, poderia causar angústia dentro do próprio movimento LGBT nas suas bases mais "conservadoras", uma angústia expressa pelo abalo na tentativa de desconstrução da relação entre minorias sexuais e promiscuidade, patologia e ignorância, promovida secularmente por uma "heterogemonia". Ainda segundo Preciado (2010, p. 64):

Certamente as políticas de identidade parecem buscar a interação na economia de mercado e dos meios de comunicação para ganhar visibilidade, em uma equação que estabelece uma equivalência entre visibilidade, representação política e emancipação.

A expressão queer, percebida no discurso da personagem, não é de fuga do binarismo, mas de uma postura que admite uma variante dentro do modelo estabelecido do "gay aceitável". Ele subverte o significado de palavras que poderiam ser utilizadas como insultos, trazendo à tona uma forma de expressar a sua subjetividade, sua vontade de ser o travesti fêmea "cachorra", de ser passiva, de escancarar a sua sexualidade.

No segundo movimento, com a personagem da obra O garanhão que lascou-se com um travesti (CAMPOS FILHO, s/d), o narrador desconstrói a imagem "inocente" que a heterossexualidade tem do travesti. Para aqueles que não têm conhecimento da dinâmica homoerótica, seja por 
ignorância ou negação, supõe-se que os travestis masculinos participam das relações eróticas necessariamente de forma passiva, visto que seus corpos e as edições feitas neles poderiam sugerir a pretensão de ocupar sempre o status feminino. Percebemos essa ruptura na cena:

Ela falou sem meiguice /- Agora eu vou lhe torar, No meio das lindas coxas / Tinha um palmo e meio de troxa / pelo que pude perceber, Disse com a arma na mão:/- Vai dar ou vai querer morrer? (CAMPOS FILHO, s/d, p. 6-7).

A cena desfaz dois equivocos: o primeiro, como foi dito anteriormente, de que o travesti teria que ser, necessariamente, passivo, uma ilusão. Um sem número de documentários, reportagens, entrevistas, dão conta de que, ao terem seus préstimos eróticos requisitados, travestis de programa relatam que a rotina é que o cliente seja penetrado, assim tendo a oportunidade de ser "a mulher de uma mulher"; o segundo equivoco é a associação da imagem do travesti à de um pênis minúsculo ou "atrofiado" por se assemelharem à figura feminina, como se ela não pudesse ser bem dotada, ter um pênis acima da média. O manuseio dos órgãos sexuais e demais orificios a fim de produzir prazer, ou não, de forma anômala ao pregado pelo pensamento straight, causa repulsa, estranheza e negação, uma vez que as práticas dos prazeres e instrumentos destas já estão inscritos na norma. Assim: 
[...] uma sexualidade qualquer implica sempre numa territorialização precisa da boca, da vagina, do ânus. É assim que o pensamento straight assegura o lugar estrutural entre a produção de identidade de gênero e a produção de certos órgão sexuais e reprodutores (PRECIADO, 2011, p.12).

Poderíamos, sem pretensões teóricas, classificar de "confusão queer" o que ocorre com o travesti na obra. Ele transcendeu o que se esperava do seu suposto sexo biológico, ele edita seu corpo, (des)territorializa sua boca, seu ânus e seu pênis, utilizando-os livremente, visando ao prazer.

No terceiro folheto, observa-se um tipo diferente de desejo, o de transceder da condição masculina para a feminina, a vontade de ser, de fazer, de sentir, sendo reprimida por uma das instituições punitivas sociais mais graves: a igreja. O fenômeno da travestilidade, em O padre que virou mulher (MENEZES, 1988), culmina na cirurgia de ressignificação sexual, que materializa o desejo cultivado pelo padre - ser mulher. Nesta obra, o padre se divide entre a performance do clérigo e o desejo de se tornar "mulher", o dilema pessoal de um sujeito que se dividia entre seu suposto "chamado" de Deus, e sua vontade, que via no "sexo oposto" seu ideal:

Pensei: então eu vou/de uma vez me decidir/ acabar com essa história/deixar de me dividir, Não vou mais repar- 
tir/a minha personalidade/eu tenho corpo de homem/mas sou mulher de verdade (MENEZES 1988, p. 7).

A personagem se vê oprimida pelo sistema sexo-político-religioso, que poda de todos os lados qualquer possibilidade de exercício da sua vontade, motivando a decisão de se rebelar. Para a personagem, a lógica queer não se aplica somente à transgressão de um padrão, ou ainda a resistência à heteronormatividade compulsória, mas, sobretudo, o que está em questão é a vontade de ser, de existir como mulher, travestindo-se, transformando-se, transfigurando-se, e não percebendo nisso o valor negativo instituído para aqueles que, como ele, procuraram satisfazer seu desejo. A lógica binária aqui não é reafirmada como pode parecer, uma vez que, mesmo almejando um lugar dentro dela, mesmo querendo ser "mulher", o padre não parte do lugar de "homem", já que lhe foram vetadas as práticas e/ou obrigações que fazem o sujeito ser reconhecido como tal - o sexo, o casamento, a prole - não que estas sejam as únicas, mas que, no entanto, podem ser tomadas como fundamentais pelo senso comum, e mesmo com o corpo ressignificado, ainda sim, dificilmente ele seria agrupado dentro da lógica binária como mulher.

A análise do comportamento queer nas três obras se manifesta de maneira plural e diversificada, assim como a proposta da teoria destaca. Além da representação de três 
personagens travestis tão diferentes, sua abordagem se faz importante no que concerne à visibilidade da múltipla possibilidade de vivenciar e de perceber o travesti e/ou o seu trabalho de edição corporal e performático que, desta forma, assinala o conceito de multidões queer proposto por Preciado (2011, p. 16):

A multidão queer com um 'terceiro sexo' ou um 'além dos gêneros'. Ela se faz na apropriação das disciplinas de saber/poder sobre os sexos, na rearticulação e no desvio das tecnologias sexopolíticas de produção de corpos 'normais' e 'desviantes'. [...] O que está em jogo é como resistir ou como desviar das formas de subjetivação sexopolíticas.

As personagens resistem, apropriam-se de técnicas e tecnologias - na elaboração do seu vestuário, no trabalho corporal e na cirurgia de ressignificação de gênero - no intuito de se tornarem sujeitos inteligíveis a si próprios, deixando claro que os corpos não são mais dóceis, que estratégias, desvios de tecnologias do corpo financiam a desontologização do sujeito sexual, ingressando e contribuindo para uma ideia de multidões queer. Esse conceito, levantado por Preciado, revela as multitudes que habitam as esferas identitárias da politica LGBT, que sujeitos alocados como lésbicas, gays, bissexuais, travestis, transgêneros, drag queens, drag kings, e tantas outras formas de 
vivência da sexualidade não cabem mais em siglas, que suas práticas são cada vez mais dificeis de ser problematizadas. Desta forma, a análise das obras propicia a reflexão acerca de personagens e comportamentos que não podem e não devem ter suas práticas e vivências homogeneizadas, pois sua materialidade deve ser encarada como única, respeitandose as diferentes subjetividades dispensando agrupamentos ou engessamentos categóricos, ainda que os termos queer e multidões queer sejam uma forma de categorização: é a categorização do (in)categorizável.

\section{Considerações finais}

Práticas discursivas vêm sendo, ao longo dos anos, analisadas como partes integrantes das estruturas sociais que corroboram ou divergem das normas estabelecidas pelas instituições de poder da sociedade. O cordel já ingressou na malha discursiva de uma cultura tradicionalmente masculinista e heteronormativa. No entanto, também, se configura como uma mídia aberta às mudanças, às representações de gênero ou representações de sexualidades mais diversas como o gay, o sapatão, o bissexual, a feminista, o transformista, o transgênero etc., sem que se faça obrigatoriamente uma abordagem negativa destes. Nas obras analisadas, os narradores, bem como seus personagens, tiveram respeitadas suas subjetividades, fosse na mudança implementada em seus corpos, fosse 
nas práticas de sua sexualidade. Não levantamos questionamentos acerca das verdades que constroem as imagens dos sujeitos, mas apontamos a possibilidade destas realizações dentro das obras sob a perspectiva queer.

O trabalho dos cordelistas, talvez inconscientemente, é importante para dar visibilidade a sujeitos e práticas que geralmente têm a sua existência e os seus desejos negados, que mesmo dentro do discurso LGBT são negligenciados ou "escondidos" por algumas alas mais fundamentalistas do movimento. Percebemos três performances distintas: a do travesti que se assume travesti publicamente e não tem pretensão alguma de ser outra coisa; o travesti que contraria o que se esperava dele e, com um pênis avantajado, curra o suposto garanhão; por fim, o padre, que se travestindo em segredo acaba por fazer uma cirurgia de ressignificação de gênero para aproximar-se do seu ideal. Elas representam a lógica queer - a nosso ver - em suas premissas mais significantes: a diversidade performática e a liberdade de práticas e desejos. Sendo assim, não é impossivel o diálogo de um gênero secular, como o cordel, com uma teoria relativamente nova, posto que o fenômeno da diversidade performática na sexualidade sempre existiu e, como vimos, foi/é representado pelos cordelistas. A teoria queer vem proporcionar uma nova perspectiva analítica de um gênero que há muito já se revela mutante e sempre atualizado. 


\section{REFERÊNCIAS}

BUTLER, Judith. Problemas de gênero: feminismo e subversão da identidade. Tradução de Renato Aguiar. Rio de Janeiro: Civilização Brasileira, 2003.

CAMPOS FILHO, Vicente. O garanhão que lascou-se com um travesti. [s.ll: s. n., s. d.].

CARRILLO, Jesús. Entrevista com Beatriz Preciado. Revista Poiésis, Niterói, n. 15, p. 47-71, jul. 2010.

FOUCAULT, Michel. Verdade e poder. In:

Microfisica do poder. Tradução de Roberto Machado. Rio de Janeiro: Graal, 1979.

História da sexualidade I: a vontade de saber. Tradução de Maria Thereza da Costa. Rio de Janeiro: Graal, 1988.

KATZ, Jonathan Ned. A invenção da heterossexualidade. Tradução de Clara Fernandes. Rio de Janeiro: Ediouro, 1996.

LOURO, Guacira Lopes. Teoria queer: uma política pós-identitária para a educação. Estudos Feministas, Florianópolis, v. 9, n. 2, p. 541-553, 2001. 
MACHADO, Roberto. Por uma genealogia do poder. In: FOUCAULT, Michel. Microfísica do poder. Tradução de Roberto Machado. Rio de Janeiro: Graal, 2007.

MENEZES, Otávio. O padre que virou mulher. [s.11: s.n, 1988.

MONTEIRO, Manoel. A briga de um gay com uma mulher macho. Campina Grande: Cordelaria Manoel Monteiro, 2009.

PÊCHEUX, Michel. Semântica e discurso: uma crítica à afirmação do óbvio. Tradução de Eni Pulcinelli Orlandi et al. Campinas: Unicamp, 2009.

PINO, Nádia Perez. A teoria queer e os intersex: experiências invisíveis de corpos desfeitos. Cadernos Pagu, Campinas, v. 28, p. 149-174, jan.-jun. 2007.

PRECIADO, Beatriz. Multidões queer: notas para uma política dos "anormais". Estudos Feministas, Florianópolis, v. 19, n.1, p. 11-20, jan.-abr. 2011.

PRINS, Baukje; MEIJER, Irene Costera. Como os corpos se tornam matéria: entrevista com Judith Butler. Estudos Feministas, Florianópolis, v. 10, n. 1, p. 155-167, [jan.-abr.] 2002. 


\title{
HOMOSSEXUALIDADE E NAÇÃO NOS DIÁRIOS DE TULIO CARELLA
}

\author{
Leandro Soares da Silva
}

A história daqueles que, oriundos de outras terras, chegaram ao Brasil e não resistiram ao registro, é uma copiosa história de estranhamento e fascínio. Seus relatos serviram de espelho para que a própria ideia de brasilidade fosse erigida, ou confirmada, e mesmo quando o exótico e o primitivo se impõem na visão desses estrangeiros, é como discurso sobre a nação brasileira que se impõem. O aparato discursivo que descreve, nomeia e controla a identidade nacional foi apoderado pelos nossos escritores desde o romantismo, onde funcionou como projeto literário, e continua atuante até hoje. De estranhos e estrangeiros que sobre esta parte do continente dispensaram algumas páginas, sejam elas de diários, cartas, romances, poemas ou relatórios governamentais, pouco conhecidas são as escritas por um professor e autor argentino que viveu no nordeste brasileiro.

1 Doutorando em Teoria Literária e Literatura Comparada, pela Universidade Federal de Minas Gerais. Professor Auxiliar de Literatura Brasileira e Portuguesa, na Universidade do Estado da Bahia. E-mail: <leocapim@gmail.com>. 
Tulio Carella é esse escritor. Viveu no Recife entre 1960 e 1962, convidado para ministrar aulas no curso de teatro, e saiu do país porque sua conduta levou à desconfiança de que estaria envolvido com contrabando. Provavelmente, naquela época, um estrangeiro frequentador assíduo do porto seria visto com muito maior receio que hoje. O que a policia descobriu, depois de torturá-lo e revistar seu apartamento, foi muito mais inesperado. Nos diários encontrados pela polícia, consta a abundante história de um homem fascinado pelo Recife e pelo Brasil, mas muito mais dedicado a descobrir o segredo por trás dos corpos negros dos homens - muitos homens - com quem fazia sexo. De volta à Argentina, Carella retrabalhou o texto do diário, transformando -o numa espécie de roman à clef. Publicou-os no Brasil em 1968, sob o título de Orgia: diário primeiro, claro que pelo seu título, pelo menos, outro viria à luz. Esgotado, o livro só receberia outra edição, em 2011, sem que novos volumes surgissem e sem que o original em espanhol fosse encontrado. A história de Carella nunca foi publicada em seu país.

Edward Said (2007, p. 15), revendo seu Orientalismo, em 2003, defende que o conhecimento de outros povos se manifesta em duas modalidades de desejo: "o desejo de compreender por razões de coexistência e de alargamento de horizontes, e o desejo de conhecimento por razões de controle e dominação externa".

O desejo de Carella é, sobretudo, do primeiro tipo: é evidente seu medo de dissolver-se, 
como argentino, no país que o recebe, mas entende positivamente o contato com pessoas com hábitos, formas de convivência e histórias tão diversos dos seus. O seu não é um olhar que pressupõe a dominação, mas, em certo ponto da narrativa, o autor - sob o alter ego de Lucio Ginarte - deixa de lado as intenções de pensar a latinidade dos individuos de uma maneira, digamos, a aproximar a experiência nordestina da de Buenos Aires, para impor a si mesmo o papel de agente portador das graças iluministas.

Citado por Homi Bhabha, Partha Chatterjee aponta a dificuldade de um nacionalismo calcado numa imagem do Iluminismo porque este, "para afirmar sua soberania como ideal universal, necessita de um Outro; se pudesse de fato se efetivar no mundo real como o verdadeiramente universal, na verdade destruiria a si próprio" (1998, p. 201). O texto de Carella, nesse sentido, não se funda em defesa do nacional ou em comparações entre nacionalidades distintas amparadas nas grandes rubricas "América Latina" ou "sul-americano", como parecia intentar. O Iluminismo aparece no ideal civilizatório de alguém que se reconhece descendente e continuador de uma cultura letrada - e se é letrada, no contexto do nordeste brasileiro, em meados do século passado, é superior.

Os diários de Carella contam a história de um desejo que desconstrói basilarmente o discurso nacional na forma de uma contranarrativa da heterossexualidade. Deslocando seu enfoque da descrição do fascínio e estranhamento, 
que a nação brasileira lhe desperta, para a descrição obsessiva de encontros realizados com homens pobres, negros e mestiços do Recife, o narrador Ginarte/Carella deixa vago o espaço para se pensar sobre a nacionalidade a partir da categoria da sexualidade.

Este texto argumentará com base na necessidade de se pensar a nação a partir de discursos que permanecem atuando de modo subalterno na constituição do imaginário nacional, tanto no aspecto homoerótico da narrativa literária quanto no aspecto, que considero mais importante, de deslizamento do monolito essencialista da heterossexualidade. Como fonte simbólica, a heterossexualidade é uma estratégia de identificação cultural de um povo questionada pelos estudos gays e lésbicos, geralmente, a partir da contraparte narrativa que põe em evidência a experiência homossexual. Mas são relatos como os de Carella que possibilitam um questionamento a partir da própria norma hetero, sem a necessidade de se chamar a identidade gay para a arena do contraponto.

A ambivalência da "nação" como estratégia narrativa, afirma Homi Bhabha, é possibilitada pela

[...] força narrativa e psicológica que a nacionalidade apresenta na produção cultural e na projeção política [. E prossegue:] como aparato de poder simbólico, isto produz um deslizamento contínuo de categorias, como sexualidade, afiliação de classe, para- 
noia territorial ou 'diferença cultural' no ato de escrever a nação (1998, p. 200 - grifo do autor).

Situando-se na zona liminar desse deslocamento, tentarei discutir a narrativa da nação sob o signo da heterossexualidade, que considero frágil e erodida, sem debater sobre a diferenciação com base na experiência de sujeitos heterossexuais. Em outras palavras, o diário de Carella serve de base a uma argumentação mais panorâmica e conceitual sobre a (hetero) sexualidade, mesmo quando recorre a exemplos mais concretos de vivência pessoal.

A história do desejo contada por Tulio Carella, em seus diários, é a história de uma nação percebida por um estrangeiro como sexualizada, mas com uma natureza masculina que até se poderia compreender como a história de um desejo homossexual. Contudo ela revela este desejo duplamente inominado: não só por causa da natureza dos atos em que se realiza, mas também por não existir qualquer possibilidade de identidade gay definida pela escrita. O desejo sob o sol do Recife é da ordem de uma estrutura masculina e heterossexual, em que o sexo rotineiro e fortuito do protagonista não se confunde com uma ideia de individuo gay.

Ainda que reconheça - e rejeite - aqueles que considera óbvios homossexuais, não é nessa esfera que Carella/Ginarte põe sua própria pulsão, nem mesmo a da maioria dos seus parceiros. Estes, assim como ele, desbastam a 
selva escura de um desejo que é quase necessidade, que flui irresistivel pelas ruas e bares, que se impõe aos corpos, como a fome, a sede, o sono. O lugar desse desejo sem nome é o espaço público onde o pouco de mulheres que são vistas - como observa o narrador - é, na maioria, de reputação duvidosa; lugar, portanto, mais uma vez, masculino e estruturado sob as relações entre homens heterossexuais.

Nas inúmeras conquistas de Carella/Ginarte não se encontra nenhum homem que se reconheça ou exerça sua sexualidade sob o dominio de um signo que seja o do homossexual. Estas figuras, com o que elas representam em termos de identidade, comportamento e trânsito específicos, aparecem à margem das narrativas, como pegajosas, moles ou insistentes, literalmente no caminho que o autor percorre em busca de rapazes e homens casados, solteiros, inexperientes ou viciados - mas que não renunciaram à estrutura da norma heterossexual. De fato, é com iguais a si que Carella, casado há vários anos, prefere se relacionar.

Ainda que se proponha a pergunta "O que é um homossexual?", depois de seu primeiro encontro com um rapaz, o narrador a abandona abruptamente pela questão "O que é um negro?", repetida algumas vezes ao longo do livro. O desejo que escorre dos diários de Tulio Carella é pelos negros e mestiços em seu cromatismo variado, numa obsessão que revela uma atração pelo exótico, ainda que o texto tente se abster desse exotismo erótico.

Ele também chega a perceber a si mesmo 
como algo excêntrico e conclui que a atração que exerce sobre os recifenses se deve à sua condição de estrangeiro, com modos, aparência e mesmo roupas diferentes dos daquelas pessoas. Claro que esse estatuto se impõe nas suas relações sexuais, que ele metaforiza como encontros entre culturas distintas. Dadas as diferenças sociais e culturais entre o escritor argentino e seus parceiros, uma relação de força se desenha: embora desempenhe um papel sexual submisso, o narrador faz uma leitura diversa. Quando um parceiro o penetra, considera que para o negro "é preciso que entre nesse corpo pálido, alheio à sua terra, para comunicar-se com os deuses brancos que o habitam, mesmo que tenha de rasgá-lo e fazê-lo sangrar" (CARELLA, 2011, p. 121).

Carella não foge de uma visão exótica e sexualizada do país, como ele genuinamente parece evitar. Sua questão tão reiterada, "o que é um negro?", encontra a resposta no fascinio pelo corpo negro masculino: para o narrador, o pênis é o melhor que os negros têm para oferecer aos brancos e, mesmo durante os atos ("Ele pega no meu pênis e eu no dele - o que é um negro?"), a questão lhe retorna mesclada à própria resposta. Esta nação, de morenos, negros, sararás e mestiços, tem-lhe basicamente a oferecer nada além de seus corpos. A contraparte dessa equação é sua postura civilizatória. $\mathrm{Na}$ universidade, trabalha como professor de teatro, registra o gosto dos alunos por suas aulas, a inveja e depois a cópia de seus métodos por outros professores. Nas ruas, admira-se e se 
preocupa com "a falta de etiqueta dos negros, de alguns negros [...] procuro semear, orientar, inculcar alguma ideia que frutifique com o tempo" (CARELLA, 2011, p. 136).

Encanta-se com o olhar demorado de King Kong, seu amante mais destacado, sobre seus óculos e livros, entende que o rapaz se fascina com os símbolos de uma intelectualidade que não possui - descrito em detalhes, King Kong é um centauro, um touro, um ser gigantesco, puro músculo, possuidor de uma malícia previsível, e não mais do que isso.

Suas relações com esses homens todos que, além de negros, são sempre pobres, leva o narrador à conclusão de que, embora haja algum preconceito, não existe discriminação racial, de que as tensões raciais se equilibram no cotidiano. Sua chave de leitura para chegar a tal conclusão é a sexualidade: "O que me atrai no Recife é a atmosfera moral, ou melhor, imoral. Isto é a África com as vantagens do Ocidente" (CARELLA, 2011, p. 168).

É nesta atmosfera que o narrador perde suas ligações originárias, aproximando-se do novo espaço a partir de uma velha conhecida, a suposta sensualidade brasileira, que se revela através do exercício ilimitado da sexualidade. A perda da "origem", contudo, se dá pela plena realização de sua necessidade de sexo homossexual. Aos poucos, Buenos Aires se constitui apenas um lugar para o qual enviar cartas. Carella/Ginarte deixa-se dissolver em solo brasileiro, ainda que jamais abandone a referência de sua pátria, que 
aqui funciona como a civilização letrada que vem fundar, nesta "África ocidental", exíguos alicerces que, de fato, são apenas simbolos de uma superioridade precária: modos de etiqueta, leituras literárias, roupas e sapatos de outra qualidade.

Sua identidade nacional não é afetada, assim como sua identidade sexual. O que o afeta ao ponto de se transformar é a prática erótica, que, no Brasil, possui um contorno obsessivo. Ainda que tantos antes e depois de Carella tenham interpretado o Brasil pela via do sexo e da sensualidade, é sua vivência numa "nação de invertidos" que sugere um olhar para os discursos subterrâneos da nacionalidade. $\mathrm{O}$ foco exclusivo na sexualidade masculina é a grande novidade dessa interpretação, pois desloca a ênfase sobre a mulher brasileira e sua sexualidade quase promíscua, conforme o cânone, para corpos de homens negros, pobres, semialfabetizados.

O corpo negro masculino é o fetiche, não o da mulata. Pergunta-se o que é um negro porque a visão o aflige como um cilício, cuja recompensa à dor de ser penetrado equivale a uma experiência mística e a uma dose de iluminismo para o povo agreste. Nação de invertidos em sua acepção restrita: invertidos não por desejarem outros homens, mas invertidos porque representam, no privado, o contrário de sua atuação pública.

O subterrâneo recifense, descrito pelo autor argentino, é uma amostra local de uma experiência mais geral e, salvo por causa de relatos 
como o seu diário, oculta da norma que organiza não somente as relações entre homens e mulheres, mas também o discurso nacional. Caso se pense na construção da masculinidade do homem nordestino, a reiteração de seu caráter de macho e da tradição que obriga este homem a ser estereotipado como rude e brutalizado, o relato franco de seus diários é uma desconstrução irreparável dessa figura. A experiência de homens e mulheres gays presume a criação de espaços de sociabilidade, onde suas identidades possam ser vividas com algum controle e com algum sossego é fato antigo e cada vez mais consolidado. No Recife da década de 1960, para Carella, esses espaços são as ruas, os banheiros públicos, a orla da cidade. A frequência, nesses lugares, de homens casados ou heteros é equiparável à de homossexuais, facilmente reconheciveis pelos seus modos e estilos de vida, aos quais o narrador não orienta sua vontade de sexo. Por isso, seu texto não é sobre uma sociabilidade gay que rasga o discurso oficial sobre a nação, mas sobre um rasgo na própria heteronormatividade nacional.

A nação que Carella descobre é a de homens heterossexuais envolvidos em sexo casual com outros homens, em troca de dinheiro, pequenos trocados, comida, vestuário e, é claro, simplesmente prazer. Heterossexuais porque suas identidades são performadas desta maneira, reiteradas cotidianamente através de práticas normativas como o noivado, o casamento, o trabalho, o comportamento público etc. Não existe perda ou ambiguida- 
de nesses homens, a não ser, é claro, nos homossexuais que o narrador nomeia ao longo do livro, assim identificados porque, por sua vez, performatizam sua homossexualidade ou assim se identificam.

Como a atração de Carella/Ginarte recai em homens pobres, invariavelmente o sexo que fazem possui uma moeda de troca. As exceções expostas pelo texto confirmam a regra: o sexo com marinheiros árabes, que chegam ao Recife e encontram no narrador o indice comum da estrangeiridade; o amigo médico do Rio de Janeiro, que lhe confidencia uma atração sexual, embora não esteja disposto a ceder. Nesses termos, a rasura evidenciada pelos diários de Carella é a de uma nação homossocial.

A homossocialidade diz respeito à dinâmica das relações entre homens, independente de suas identidades sexuais, e ao modo como a masculinidade é exercida e construída. A nação homossocial descrita pelo escritor argentino é um espaço para se pensar além da homossexualidade, pois é sobre a masculinidade oficial que ela versa, ou melhor, sobre os não-ditos dessa masculinidade.

Os matizes existentes no universo de homens que fazem sexo com outros homens são inúmeras; passam do homossexual assumido ao gay no armário, o qual difere de homens que ocasionalmente transam com outros e que, ainda assim, não possuem qualquer identidade homossexual, apenas desejo. E um desejo que não precisa ser exclusivo ou vivenciado numa tortura. Como a experiência de Carella 
deixa claro, não há culpa sob o Sol do Brasil, muito menos pecado. Sobre esses homens, revoa o barulho dos discursos acerca da homossexualidade, da identidade gay, da luta pelos direitos civis dos LGBT e da criminalização da homofobia. Mas em que espectro da sociedade eles estão, se vivem plenamente na heteronormatividade e dela não pretendem sair? A sigla $\mathrm{HSH}$, utilizada oficialmente pelo Ministério da Saúde, por exemplo, coloca a questão em termos mais assépticos do que culturais, embora seja eficiente em não demarcar nenhum tipo de identidade sexual. Como o contexto exposto por Carella é o de homens que se identificam e performatizam a heterossexualidade, a questão permanece problemática.

A sexualidade funciona como um dos vários discursos sobre o nacional, no Brasil. Geralmente apoia-se na sexualidade feminina e na liberalidade de costumes que constituem vários dos discursos pedagógicos da nação, como, por exemplo, o carnaval. O debate sobre isso já avançou muito e assim prossegue, agregando a este discurso a crítica necessária que expõe as contradições de nossa tão falada sensualidade. O fato de o homossexual e sua experiência não se situarem mais no gueto tem sido um item candente da agenda de hoje, ainda que a tática mais conhecida para isso seja a de rearranjar gays e lésbicas, no interior da heteronormatividade, o que resultaria na equivalência discursiva dessas identidades, subtraindo-lhes o potencial desestabilizador da diferença, que permanece forte nos indivíduos transexuais. 
Essa equivalência substitui a ausência de uma proposta homossexual à norma hetero que vingue além do carnaval. É um modo astucioso de adquirir acesso aos direitos civis mais básicos, e atingir tal igualdade que demonstra como a homossexualidade não foi capaz ainda de criar uma alternativa forte à performance heterossexual em que todos os individuos são treinados. A luta por esses direitos, embora seja mais que válida, vai ao encontro da norma em diversos niveis, porque torna homogênea a experiência diversificada de lésbicas, gays e transgêneros. Mesmo as investidas na cultura popular, no cinema e na literatura não têm dado conta, por exemplo, da complexidade identitária de uma lésbica que seja negra, ou de um cross-dresser, ou de quem fez a transição do feminino ao masculino. Já o bissexual permanece nesse quadro como invisível, indeciso ou falso.

Nesta discussão não existe lugar, ainda, para a multidão de homens cuja performance hetero admite o sexo gay, sobretudo porque já estão instalados confortavelmente no interior da heteronormatividade, seja como gays no armário, bissexuais ou admiradores ocasionais (ou não) de sexo homossexual. Estes mesmos homens, contudo, participam como genuínos reiteradores da heterossexualidade e do discurso nacional em suas vidas e vivências. Não têm necessidade de lutar pelo direito do casamento civil, porque já o possuem; não precisam apoiar a criminalização da homofobia, pois não correm o risco de suas performances 
serem confundidas com as de um homossexual; não precisam do conforto de um gueto, pois toda a cidade pode ser sua. Estes homens só têm a preocupação de encontrar o espaço de sociabilidade necessário para a realização de suas práticas, muitas vezes dividindo-o com sujeitos que se identificam como gays.

Os diários que Tulio Carella escreveu no Recife são a história desse indivíduo muito mais astucioso e muito mais adaptado à dinâmica da norma do que seus compatriotas LGBT. Mas a história desses diários também é a desconstrução da identidade masculina heterossexual, seu desejo, sua performatividade e sua legalidade. $O$ texto dilata a ideia de sexo entre homens como forjado pelas necessidades compulsória e monetária ou pela doença, vício e pecado para o campo do mero prazer. Indica que as repetições ritualizadas que nos informam o que é o macho nordestino e o que ele representa se diluem sob a égide do desejo indiscriminado. Seu texto funciona como contradiscurso de uma sexualidade heterossexual que está no cânone da ideia de nação, e da sensualidade brasileira exclusivamente feminina.

A trama que envolve gênero, raça e nacionalidade é intrincada e pouco convidativa a uma análise que não se deixe seduzir pela observação dessas três categorias em separado, mas a experiência vige como relatora de que não se pode pensar como estanques as identidades de gênero e raciais, e mesmo como estas se mesclam na construção do discurso nacional. Avtar Brah (2006, p. 351) 
afirma que "estruturas de classe, racismo, gênero e sexualidade não podem ser tratadas como 'variáveis independentes' porque a opressão de cada uma está inscrita dentro da outra - é constituída pela outra e é constitutiva dela" (grifo do autor).

As indias nuas de Caminha, as imprecações contra sodomitas mulatos feitas por Gregório de Mattos, a mucama Lucinda que perverte sexualmente sua ama, nas Vitimas -algozes, de Macedo, ou as heroínas de Jorge Amado, para citar exemplos que não intentam ser específicos e fechados, são amostras produzidas em solo brasileiro eivadas de implicações entre raça, gênero e classe que contribuiram e ainda retornam fantasmagoricamente para contribuir com a construção de uma nação sensual. O problemático desses discursos simbólicos é que suas leituras tendem, na maioria das vezes, a demonstrar a dificuldade de pensar como um território se transforma em nação, considerando-se, no processo, como as identidades de gênero e de raça, assim como as de classe, foram importantes para a construção desse imaginário.

Como o espaço público é pautado na estrutura da produção e das transformações fixadas por homens, a nação torna-se um discurso masculino e heterossexual, em que mulheres, homossexuais, não-brancos e pobres participam de modo subalternizado. As múltiplas relações de dominação no bojo da colonização, em que todos participaram em determinada escala, possuem pouquíssimo registro que sir- 
va de suporte a uma invectiva contra o status heterossexual da nacionalidade.

Em Orgia, a invectiva, contra o nacional, parte das relações sexuais pouco precisas no plano da identidade, mas bastante acertadas no plano do desejo, entre uma turba de indivíduos homens, heterossexuais, pobres e negros e um estrangeiro. A própria ideia masculina de nação que essa turba representa é cuidadosamente erodida pelo relato do estrangeiro, que corrói sua suposta heterossexualidade radical.

Neste jogo, Carella não consegue fugir da fetichização e de certa ideia tortuosa de colonialismo. $O$ fetiche pela cor negra lhe atiça diariamente a carne, leva-o a uma busca impressionante, de tão obsessiva, por novos homens com quem se deitar. Sua versão do colonialismo (na verdade, seu dom civilizatório) é dar a esses homens a contraparte fetichista, isto é, dar aos negros rudes o refinamento simbólico de sua brancura. Quando um de seus pretendentes revela interesse por teatro, descarta-o com a desculpa de que não quer estabelecer pontes entre esses dois mundos. Os mundos - que o autor não nomeia - são, por um lado, a civilização letrada, que ele oficialmente representa como professor universitário, e o submundo do sexo, em que investe sua energia com bastante determinação. Contudo, a verdadeira ponte desse episódio não seria Carella, mas sim o rapaz interessado em teatro, que representaria o negro com gostos e hábitos mais próximos dos seus, e por isso, sem o fetiche original que o atrai: o fetiche do negro inculto. 
As relações de raça e classe existentes entre homossexuais e homens pobres, que continuam a vivenciar sua heterossexualidade, apesar de às vezes sustentar suas vidas e as de suas mulheres e filhos com dinheiro de amantes gays, são um fenômeno bem conhecido por sociólogos e, inclusive, socialmente aceito nas comunidades mais carentes. Diferindo dos michês, que participam dessa dinâmica na forma de serviço esporadicamente prestado, esses homens mais pobres atuam, com seus amantes homossexuais, num ambiente em que a fetichização também ordena e é tão importante quanto o intercâmbio financeiro. Na prostituição masculina, qualquer ilusão de desejo genuíno é derrubada ao primeiro anúncio do preço dos serviços, enquanto nas relações aqui aludidas supõe-se que o dinheiro seja um facilitador do prazer. Nos diários, isto se manifesta através das intenções do narrador - jamais verbalizadas - de viver com King Kong para mitigar sua solidão e desejo em troca não só de um teto, mas também de algum dinheiro e educação. O que o impede de externar ao parceiro essa vontade, além da desconfiança da recusa, é o receio de viver com um outro tão diferente de si.

Embora muito distinto de homens gays que mantêm relações de concubinato com heterossexuais, Carella trabalha na exposição de uma dupla rasura: a primeira, que diz respeito ao modo como a heterossexualidade, ou como essência masculina ou como caráter nacional, é uma performance reiterada que mostra as 
falhas de sua estratégia em segredo, inclusive deformando o ideal de homem nordestino; a segunda, no papel que negros e mestiços têm no discurso nacional, pois o narrador compreende todo o povo como matizado e não-branco. Por outro lado, seus diários repetem as fórmulas do exotismo tropical, da sensualidade exagerada do brasileiro e de virilidade do homem negro. O fato de serem três lugares-comuns do discurso nacional parece, portanto, corroborar suas impressões.

A ideia de nação é amplamente unificada, entre outros índices, pela heterossexualidade compulsória. Não é apenas como anormais que pessoas gays, lésbicas e trans participam das narrativas nacionais: em determinados âmbitos, essas pessoas sequer existem, ou funcionam como a diferença que justifica a norma. Clamar visibilidade para as narrativas homossexuais como atuantes no processo metafórico nacional talvez não possua o mesmo poder desestabilizador que é questionar, como o texto de Carella permite a própria narrativa oficial da nação no seu estatuto heterossexual. A contranarrativa da heterossexualidade pode ser lida numa chave diferenciada daquela proposta pelos discursos homossexuais na medida em que desloca e questiona o essencialismo sexual em sua forma compulsória. As contranarrativas, diz-nos Bhabha (1998, p. 211),

[...] continuamente evocam e rasuram suas fronteiras desestabilizadoras tanto reais quanto conceituais - perturbam aquelas manobras ideológicas 
através das quais 'comunidades imaginadas' recebem identidades essencialistas (grifo do autor).

A fantasia homoerótica que descreve uma nação como invertida, isto é, com uma heterossexualidade rasurada, impõe-se como reveladora da performance de gênero e, ainda mais do que isso, desarticula a estrutura do discurso nacional de caráter sexual. Essa desarticulação pode ser aproveitada tanto pelas contranarrativas gays, que reivindicam sua participação na metáfora nacional, quanto num reposicionamento do local da heterossexualidade como prática normativa.

Em outras palavras, essa mudança revigora o discurso pós-identitário de gênero como performance ao mesmo tempo em que atua como desconstrução da heterossexualidade nacional. Portanto, em primeiro lugar, isto diz respeito ao questionamento da sexualidade "oficial" como uma invenção cuja narrativa é reiterada num tempo performático, diário; em segundo lugar, essa mudança questiona a representação do "homem nacional", revela os deslocamentos e falhas de sua construção e mesmo joga uma pá de cal na ideia essencialista de heterossexualidade.

Estas contranarrativas também denunciam a maneira pela qual a masculinidade de uma nação é construída a partir da repressão do feminino e do posicionamento público destinado ao homem. Ação entre amigos com identidades e práticas heteronormativas, este 
tipo de sexo homossexual - e anônimo - serve como iteração do papel dominante do homem ou como relaxamento dessa fronteira, quando o macho heterossexual deixa-se penetrar por outro. Para que isto faça sentido, é preciso recorrer ao lugar-comum amplamente reconhecido de que o indivíduo penetrado é um ser passivo numa função subalterna, o que vale tanto para mulheres quanto para homens neste último caso, aliás, ser exclusivamente aquele que se entranha não necessariamente constitui índice de homossexualidade; pelo contrário, é possivel até mesmo compreender isso como expressão de virilidade extrema. Esta lógica do senso comum é quebradiça, apenas substituição e fuga, formulada por uma mentalidade pouco sutil. Carella, que sem dúvida percebia a contradição dessa ideia, assim estabelecida de ser penetrado por outro homem - negro - funciona como fetiche e ritual de dominação: o branco é um deus subjugado pelo negro, que encontra aí o motivo de sua atração.

O discurso erodido da heterossexualidade, contudo, tem no plano diário sua concretude física (e também simbólica) nos espaços de socialização que não podem ser chamados apropriadamente de gays - mas sim de homossociais. Estes espaços contemporâneos - cinemas pornográficos, saunas, cabines de sexo etc. - ainda que sejam frequentados por homens gays fora do armário, têm sua razão de ser na invisibilidade que proporcionam, funcionam ao revés de boates, bares ou festas vendidas sob a 
sigla GLS, que apresentam abertura irrestrita para indivíduos de qualquer orientação sexual, lugar para a presença de mulheres, e territórios de celebração política da visibilidade e afirmação identitária. Como as ruas do Recife de Carella/Ginarte, os espaços para sexo anônimo são locais em que o masculino se reitera, seja pela estrutura relacional exclusivamente masculina, seja pela satisfação do desejo sob o resguardo de fachadas discretas e austeras, em que a identidade hetero apenas momentaneamente se perde. A própria dinâmica é a de uma sociedade secreta, na base do acordo de cavalheiros e do voto de silêncio, com homens reunidos para algumas horas de diversão entre si - a socialização e o sexo vêm confirmar o estatuto masculino oficial.

Estas zonas invisiveis da cidade moderna servem de desafogo da heterossexualidade nacional, que ali deixa aparecer brevemente sua fragilidade conceitual para de novo voltar a recuperá-la no retorno à vida pública. O texto de Carella, que como diário é um produto do imaginário, encontra o mundo e o expõe, mas cede ao ser apropriado como um discurso homossexual e representativo da identidade gay, isto é, perde sua força disruptiva ao mesmo tempo em que apenas se junta à contranarrativa da sexualidade homossexual. Espera-se que a leitura aqui apresentada tenha demonstrado o poder problematizador desse texto em sua contestação da narrativa heterossexual. 


\section{REFERÊNCIAS}

BHABHA, Homi K. O local da cultura. Tradução de Myriam Ávila et al. Belo Horizonte: EdUFMG, 1998.

BRAH, Avtar. Diferença, diversidade, diferenciação. Cadernos Pagu, Campinas, n. 26, p. 329-376, jan.-jun., 2006.

CARELlA, Tulio. Orgia: diário primeiro. São Paulo: Opera Prima, 2011.

SAID. Edward. Orientalismo. Tradução de Rosaura Eichenberg. São Paulo: Companhia das Letras, 2007. 


\section{LESDROIDES, TRANSBORGUES, INTERALIENS: PERSONAGENS CIENTÍFICO-FICCIONAIS ALÉM DAS FEMBOTS}

Luana Barossi ${ }^{1}$

O intuito deste artigo é apontar como um estereótipo de personagem é capaz de reproduzir relações de poder e, desta forma, servir como um reforço para a conservação do status normativo das culturas. Igualmente, apresentarei algumas narrativas que promovem desterritorializações destes estereótipos, e, como consequência, possibilitam agenciamentos narrativos no processo de apreciação da obra, que podem colaborar para mudanças no plano extraliterário.

O motivo científico-ficcional da fembot, abreviação de female robot (robô fêmea), foi paulatinamente estereotipado - da mesma forma que grande parte das personagens ficcionais femininas - como uma espécie de representação do status binário, sexista, heteronormativo e cisnormativo das sociedades. Um critico adepto de teorias estritamente representacionais nas

1 Doutoranda do programa de Estudos Comparados de Literaturas de Língua Portuguesa na Universidade de São Paulo.

E-mail: 〈luanabarossi@usp.br〉. 
narrativas literárias, ou seja, que acredita que a função maior das narrativas seja a representação de uma suposta realidade, poderia alegar que os autores de narrativas cientifico-ficcionais cumprem bem esse dito objetivo. No entanto, prefiro optar por uma perspectiva multifacetada, que considere diversos sentidos que as narrativas literárias podem assumir no processo de apreciação, pois "o livro como imagem do mundo é de toda maneira uma ideia insípida" (DELEUZE; GUATTARI, 1995, p. 13).

A inserção desses textos nas culturas, não unicamente como forma de representá -las, mas como parte integrante delas, permite o agenciamento de significações distintas das que se naturalizam como algo válido a priori, sem questionamentos. Em outras palavras, como parte integrante das imaginações constituintes dos leitores, as narrativas literárias oferecem a possibilidade de desterritorializar acontecimentos anteriormente banalizados nos elementos extraliterários do imaginário coletivo. Para Deleuze e Guattari (2001), os territórios não são apenas espácio-temporais e materiais, mas qualitativos. Cada território engloba ou perpassa territórios de outras instâncias, em conexões múltiplas. No entanto, assim como a desterritorialização material é possivel, a desterritorialização de conceitos preestabelecidos também o é. E a literatura pode servir como matéria de agenciamento dessas desterritorializações.

Assim, da mesma forma que elementos das narrativas "reais" são encontrados nas 
narrativas literárias, torna-se possivel notificar que as narrativas literárias agenciam desterritorializações nas narrativas reais. Tal ocorrência não se dá de forma binária, mas rizomática (DELEUZE; GUATTARI, 1995). Não se sabe onde uma começa e a outra termina, num constante fluxo responsável pela multiplicidade de acontecimentos.

Quando aludo ao termo "motivo", refirome a algum elemento da narrativa ou a determinada característica de uma personagem que possa fornecer informações gerais ao leitor sobre o contexto narrativo. Alguns desses motivos são tão recorrentes e fixados culturalmente que acabam por estabelecer estereótipos muitas vezes opressores e que servem como ferramenta para perpetuar estruturas de poder no imaginário social, como é o caso da fembot nas narrativas científico-ficcionais. As personagens são esculpidas de acordo com o estereótipo, ou seja, é um indivíduo criado ou moldado para cumprir o papel social de coadjuvante à personagem masculina ou, em casos extremos, unicamente para suprir suas vontades e desejos.

Um exemplo extremo deste modelo de personagem é Helen, da obra Helen O'Loy, de Lester del Rey (1938). Helen é um robô criado e programado para ser uma mulher nos moldes exigidos pelos homens da época: "um terço beleza, um terço sonho e um terço ciência" (DEL REY, 1938 p. 62 - tradução livre). De acordo com Veronica Hollinger (2003, p. 126): 
Não é necessária uma leitura muito sofisticada para perceber como essa história, uma fantasia convencional de poder sobre a criação de vida artificial, corrobora a duradoura marginalização da mulher na cultura ocidental. Como muitas histórias desse tipo, o resultado é uma 'mulher' praticamente sem individualidade ou ação, um triunfo tecnológico que desterritorializa as mulheres (grifo da autora tradução livre).

A repetição desse modelo ad infinitum na literatura e em outras narrativas (filmes, propagandas comerciais e até livros didáticos) perpetua essa territorialização da figura feminina e de figuras representantes de grupos identitários (lésbicas, gays, transexuais, intersexuais etc.) à margem, estabelecendo-lhes papéis sociais ou de acessórios do homem ou de seres doentes ou defeituosos, no imaginário de parte dos leitores. A falta de iniciativa de alguns autores em mudar este quadro nas narrativas auxilia a manutenção desta territorialização no imaginário coletivo.

O motivo da fembot neste texto não restringe, portanto, seu conceito ao robô com forma feminina, mas aos sentidos atribuídos a ele e estendidos a outros personagens científico-ficcionais que poderiam corresponder a indivíduos marginalizados. Estes sentidos limitam as personagens a uma forma de objeto usado para atender aos desejos masculinos ou conservar as estruturas de poder sociais de determinado território, em especial no que 
concerne às questões de gênero e sexualidade. As narrativas literárias, como parte das culturas nas quais estão inseridas, participam do agenciamento das imaginações constituintes dos leitores. Cada apreciador é único, dotado da condição humana da pluralidade (ARENDT, 2007), constituida por suas subjetividades, identidades e identificações com programas de verdade distintos. O conceito de programas de verdade utilizado corresponde à concepção de Paul Veyne (1984, p. 31), para quem a verdade é uma palavra que não se deveria empregar senão no plural: "só existem programas heterogêneos de verdade". Estes programas, formados através de complexos processos genealógicos - entendendo-se genealogia, através das proposições de Michel Foucault (1979), sobre relações de poder - são como pacotes que constituem as narrativas coletivas e, consequentemente, influenciam nos processos de subjetivação individuais. Para esses processos de subjetivação, adoto uma leitura do conceito de sujeito nômade, de Rosi Braidotti (1994), que figura a ideia de subjetivação através de uma consciência crítica que busca explorar e legitimar a ação politica, tendo como evidência histórica o declínio do metafisicamente fixo e das identidades estáveis. Ao considerar que as identidades estão em constante transformação e mudança, a autora as chama de nômades: acontecem num processo contínuo de devir (becoming). Desta forma, podem se amalgamar a questões que se desenrolam durante a apreciação de obras literárias de modo 
a transformar o que estava apenas aparentemente fixo pelos programas de verdade.

Esta transformação está, de certa forma, subentendida na definição de science fiction, dada por Darko Suvin (1979). O autor alega que a condição necessária e suficiente para a ciência ficção corresponde à presença de estranhamento e de cognição, lendo-se cognição sob uma perspectiva ampla, de reconhecimento com algo que está posto como real em determinado contexto; e estranhamento como algo que se afasta da ambientação corrente. Desta forma, com relação aos programas de verdade territorializados culturalmente acerca de gênero e sexualidade, grande parte das obras cientifico-ficcionais apresentam apenas cognição, pois não produzem um efeito de estranhamento, mas propagam estereótipos que trazem reconhecimento, corroborando a manutenção do pensamento heteronormativo e sexista proveniente das imaginações constituintes dos leitores. Levando em consideração esta temática, portanto, estas obras não atingem as condições necessárias e suficientes para serem chamadas de ciência ficção:

Como a História desde o Renascimento demonstra, é constante que o sujeito correspondente à 'natureza humana' universal seja branco, homem e de classe média. Nas narrativas desses sujeitos, a tendência foi alocar as mulheres em papéis coadjuvantes como 'outro' dos homens (HOLLINGER, 2003, p. 125 - grifos da autora - tradução livre). 
Assim, as literaturas criadas com objetivo único de representar uma realidade existente sem procurar oferecer ao leitor o vislumbre crítico acerca dela não proporcionam proposições de mudança. Adiciono às palavras de Veronica Hollinger a tendência heteronormativa e cisnormativa dessa História da "natureza humana". As personagens científico-ficcionais muitas vezes foram elaboradas para seguir e manter esses padrões.

Uma das questões firmadas por essa tendência em narrativas científico-ficcionais, mas que não se restringe às fembots, é a redução das personagens femininas às suas funções reprodutivas ou sociais. No entanto, tal ocorrência na narrativa não é necessariamente responsável pela manutenção do estereótipo. Algumas delas, exatamente por se estabelecerem como exacerbações dessa condição, podem aguçar a percepção crítica e o olhar atento do leitor para esse tema no processo de apreciação. Um exemplo é como a definição dos papéis femininos na sociedade de Gilead, na obra The handmaid's tale, de Margaret Atwood (1985), mostra o apagamento das subjetividades e dos desejos femininos. Como podemos, então, detectar se determinada narrativa prima pela manutenção dessa condição ou propõe questionamentos críticos sobre ela?

Proponho alguns recursos para pensar sobre possiveis desdobramentos dos motivos nas narrativas: se eles são cissignificativos, ou seja, não propõem mudanças subjetivas ou culturais no processo de apreciação da obra; 
ou transsignificativos, ou seja, agenciam, no processo de apreciação, questionamentos acerca de padrões ou generalizações reproduzidos até o momento como verdades únicas, possibilitando a promoção da desterritorialização desses padrões.

O primeiro recurso e quiçá o mais discutido, nos estudos de ciência ficção sob outras perspectivas, é a narrativa com eixo temático utópico. Apesar de as teorias, acerca da utopia, diferirem entre si por proporem ideias semelhantes com objetivos opostos, elas sustentam um ponto comum: a substituição de aspectos displicentes de determinada conjuntura concreta existente por elementos que tornem as circunstâncias ideais. Tal troca das circunstâncias e situações correntes pode ser vista tanto como evasão, já que a nova configuração pode ser quimérica, quanto como expectativa de algo praticável. Através da classificação de Mumford (2007), pode-se diferenciá-las como utopias de escape e utopias de reconstrução: aquela caracterizada pela fuga do presente insatisfatório, como uma heterotopia para onde se pode abrigar e fugir da realidade, já que se acredita que a realidade é imutável; enquanto esta propõe um escape possivel no futuro, através da reconstrução do mundo real ao efetivar no plano palpável, o que se propõe na construção narrativa utópica.

Através da proposição de uma ambientação perfeita, é possível isolar um aspecto da narrativa e apreender seus possiveis desdobramentos com relação à determinada 
condição. Contudo, um topos supostamente utópico não propõe necessariamente desterritorializações das relações de poder. Isso porque as experiências das personagens são diferentes em uma mesma ambientação, pois suas identidades nômades passam por processos de subjetivação distintos. Logo, o que é aparentemente perfeito para uma personagem, não o será, necessariamente, para outra. A utopia é, portanto, relativa.

Devemos perguntar, desta forma, se a narrativa considera, neste topos, a alteridade. O "outro", na narrativa, é visto como sujeito? Se o centro da História contada no Ocidente foi o homem, branco, heterossexual, na narrativa ficcional em questão, o topos é utópico apenas para o individuo que cumpre essas premissas? Se nos colocarmos sob a perspectiva das personagens “outras", elas são apenas outras em relação àquele sujeito? Ou elas são sujeitos elas mesmas? O topos é utópico para elas também? E, caso não seja, são mostradas as consequências do apagamento das suas subjetividades? Não devemos cair na falácia, contudo, de considerar uma perspectiva por meio da negação de outra. O desmantelamento do imaginário que envolve o estereótipo da fembot, por exemplo, não deve estar pautado na criação de outro modelo normativo, que pode excluir outras possibilidades de subjetivação das identidades nômades.

A narrativa de The left hand of darkness (A mão esquerda da escuridão), de Ursula K. Le Guin (1969), poderia ser considerada uma 
dessas utopias de gênero tanto no sentido de mostrar uma quebra no que é culturalmente estabelecido quanto por ser uma obra polifônica. A obra é constituída por uma série de "documentos oficiais" sobre o planeta Inverno (Winter) - ou Gethen, na lingua local - a ser prospectado para a Ekumen, uma espécie de liga interplanetária de relações internacionais. Fazem parte desses documentos: descrições etnográficas em primeira pessoa, em especial pelo personagem Genly $\mathrm{Ai}$, enviado a Gethen com a missão de convencer seus governantes a ingressar na liga ecumênica; trechos do diário da personagem getheniana Estraven, além de poemas e lendas de Gethen. Uma das consequências da obtenção de uma história formada por vozes narrativas diferentes é a compreensão de distinções na percepção de si mesmo (personagem com voz narrativa que se apresenta como protagonista) e do outro (estrangeiro em relação ao primeiro) em espaçostempos diferentes. Na narrativa, o primeiro estranhamento transcultural (e biológico) se dá na descrição de Genly Ai sobre a sexualidade dos habitantes do planeta Gethen:

Meus esforços se materializaram inconscientemente: primeiro de ver um getheniano como homem, depois como mulher, forçando-os nestas categorias tão irrelevantes à sua natureza e tão essenciais à minha (LE GUIN, 1969, p.12 - tradução livre). 
Genly é humano como concebemos, enquanto os gethenianos não têm sexo biológico nem gênero definidos:

\begin{abstract}
Quando você conhece um getheniano, não pode e não deve fazer o que uma espécie com dois sexos naturalmente faz, que é classificá-lo no papel de homem ou mulher, adotando expectativas do que é padrão ou das possiveis interações entre pessoas do mesmo sexo ou de sexos opostos. Todo nosso padrão de interação sócio-sexual não existe aqui. Eles não podem jogar esse jogo. Eles não se veem como homem ou mulher. É quase impossivel para nossa imaginação aceitar isso. Qual é a primeira pergunta que fazemos sobre um bebê recém-nascido? (LE GUIN, 1969, p. 91- tradução livre).
\end{abstract}

Joanna Russ (1973), em uma crítica à obra de Le Guin, alegou que o fato de a autora impor um homem como narrador principal (Genly Ai) proporciona ao leitor apenas uma visão masculina de Gethen; além de alegar que o "herói nativo" (Estraven) é homem, se não em sexo, pelo menos em gênero. Contudo, a crítica de Russ, ainda que parta de teorias feministas, é marcada pela ideia binária de gênero, o que a faz enxergar a personagem Estraven sob essa perspectiva. Ela mesma parte do pressuposto de que há comportamentos que dizem respeito a um ou outro gênero para classificar a personagem como tal. No entanto, Estraven 
é interssexual, um indivíduo que pode ser macho ou fêmea biologicamente, e que não tem nenhuma característica definidora de gênero, já que sua cultura não demanda tal normatização. Essa narrativa traz ao leitor a possibilidade de questionar a fundo as concepções de gênero e os papéis sociais da sua cultura.

No contexto de grande parte das sociedades contemporâneas, desde o nascimento, ou mesmo antes, uma série de papéis e características nas formas de agir e pensar são preestabelecidos por normas sócio-histórico-culturais. O quarto do bebê menino é azul e com temática de carrinho ou esportes; o quarto do bebê menina é rosa com babadinhos; as roupas e os brinquedos da criança são específicos para o gênero, e há um estranhamento fenomenal caso um menino venha a usar vestidos, por exemplo. Desde a mais tenra infância, a herança cultural desses espaços faz com que se imagine que essas características sejam naturais, ou seja, os programas de verdade que "gerenciam" o gênero e a sexualidade são binários. Desta forma, vive-se em uma constante banalização dos estereótipos estabelecidos culturalmente, sem levar em consideração que esses ideais binários foram criados e difundidos e seguem na imaginação constituinte coletiva.

As personagens gethenianas, se lidas sob uma perspectiva comparativa, colaboram para a dissolução dessa normatização: quando em kemmer, ou fase correspondente à emergência sexual, os gethenianos adquirem a forma 
biológica ou de homem ou de mulher, dependendo de fatores externos, como outras pessoas em kemmer por perto. Isso não significa que adquiram características de gênero socialmente construídas porque, para o povo de Gethen, isso não existe. Somente um narrador que possui a carga sociocultural do leitor torna possivel a compreensão da diferença. Quando em somer, ou período de latência sexual, os órgãos sexuais dos gethenianos desaparecem, numa espécie de (re)metamorfose ao andrógeno. Enquanto para a personagem com características socioculturais e biológicas "terrenas" as relações e características são inicialmente fixas nos binarismos homem -mulher; masculino-feminino, sendo sempre as instâncias mulher/feminino secundárias ao "caule central" homem/masculino, as personagens gethenianas vivem em um processo infinito de devir.

Portanto, ao contrário do que Joanna Russ propôs em sua crítica, Le Guin consegue desfamiliarizar na narrativa a noção binária de gênero. $\mathrm{E}$ o ponto de vista masculino do narrador possibilita exatamente enxergar a narrativa a partir de uma perspectiva que nos é comum e, desta forma, compreender como essas questões são naturalizadas na nossa imaginação constituinte, o que sugere consequente ação de mudança. Genly Ai, no decorrer da narrativa, passa, dentro do que é possivel à sua perspectiva originalmente binária, a compreender que suas noções são estabelecidas culturalmente e que são passíveis 
de serem transformadas através do reconhecimento do outro (Estraven) como individuo.

O reconhecimento do outro alude ao segundo recurso para observar se as narrativas podem colaborar para a desterritorialização do que é falsamente estável: a narrativa traz à tona o ponto de vista ou a perspectiva dessas personagens outras ou apenas analisa de fora, superficialmente? A descrição e a narração de suas características e experiências são mostradas por ela mesma; por um narrador onisciente ou sob uma estrutura narrativa que desconsidera seu ponto de vista?

Grande parte das obras classificadas como ciência ficção, sejam elas literárias ou filmicas, desconsidera a alteridade, como se o ponto de vista de uma personagem ou grupo de personagens fosse sempre necessariamente superior ao dos outros. É como se buscassem a simpatia do leitor ou espectador para si e sua perspectiva, tornando o outro invisivel. Um exemplo extremo é a narrativa do filme escrito por Chris Bertolini e dirigido por Jonathan Liebesman: Invasão do mundo - Battle L. A. (2011), ou de muitos outros que focam tanto na criação de efeitos especiais que acabam por desviar a atenção do espectador de questões relacionadas à banalização de conceitos. Extraterrestres chegam ao planeta Terra e têm a forma de monstros destruidores. O objetivo dos terráqueos é destruir esse suposto inimigo, e assim o fazem. Não há nem tentativa de leitura da perspectiva do outro. Parte-se do pressuposto de que o outro não tem ponto de vista algum, ele está lá como um objeto a ser destruído. 
No momento em que o leitor ou o espectador assumem que uma perspectiva dominante é necessariamente a certa em detrimento de outras possiveis, consentem com a manutenção das relações de poder existentes, mesmo que se identifiquem, na sua narrativa "real" com algum grupo marginalizado. Esse individuo torna-se responsável, ainda que de forma passiva, por perpetuar essas estruturas. Se, ao assistirmos um filme em que extraterrestres chegam ao planeta Terra e são dizimados pelos exércitos locais sem antes terem a oportunidade de expor seus objetivos, anseios e afetos, torcemos pelos terráqueos porque os alienigenas nos parecem abjetos, somos automaticamente cúmplices da banalização desta objetificação do outro e da manutenção do status normativo da cultura. Assim, um bom recurso para detectar obras que sugerem uma desbanalização é observar se as perspectivas das personagens são mostradas de forma polifônica, ou se a personagem, que faz parte da suposta "minoria", tem voz em algum momento.

A narrativa The Handmaid's Tale, de Margaret Atwood (1985), corresponde ao diário de uma personagem feminina em Gilead, uma sociedade dominada por homens. Não sabemos o nome original da personagem, apenas o nome que lhe foi atribuido: Offred. Se prestarmos atenção à estrutura do nome, percebemos que é constituída por uma preposição que indica posse (of) e por um nome masculino (Fred), o que significa que mesmo seu nome, que seria um marcador de individualidade, é a materialização 
da subjetivação ao outro dominante, como se a mulher fosse território do homem. A narradora -personagem tem memórias do tempo anterior ao golpe de estado, o que serve como um marcador comparativo significante à experiência do momento em que narra. Esta sociedade patriarcal, militar e que usa a religião como desculpa para a dominação, tem os papéis femininos muito bem definidos. As subjetividades e os desejos das mulheres não têm importância alguma. As marthas são mulheres que cuidam dos afazeres domésticos nas casas das wives (esposas). Elas não podem manter relações sexuais de qualquer tipo. As wives vivem em função de seus maridos e quase não saem de casa, mas ainda podem se reunir com outras wives e conversar livremente. A maioria dessas esposas é estéril, provavelmente em decorrência da exposição à radiação.

Desta forma, um novo papel social feminino foi criado: o de handmaid, que corresponde a mulheres treinadas para terem filhos para essas famílias, e não têm direito a nenhum tipo de relacionamento afetivo. Vivem em função das famílias para as quais elas concebem crianças e não podem nem conversar entre si sobre questões pessoais. Não têm um território seu, são completamente dessubjetivadas pela sociedade patriarcal disciplinar. Offred limita-se, então, a ter individualidade apenas em sua mente, como se este fosse um espaço físico onde teria direito de fazer o que quisesse, mesmo que, teoricamente, a seu status social nem isso fosse permitido: 
A noite é minha, meu próprio tempo, para fazer como eu quiser, desde que eu esteja quieta. Desde que eu não me mexa. Desde que eu fique imóvel. [...] a noite é meu tempo livre. Para onde irei? (ATWOOD, 1985, p. 47 tradução livre).

Nestes momentos, à noite, deitada e imóvel, Offred se lembrava da filha que fora arrancada dela, do marido que fora provavelmente assassinado, quando tentava fugir de Gilead e da amiga Moira.

A situação distópica para a personagem apesar de utópica para os indivíduos que estavam no poder, pois podiam manter o controle de seus territórios - pode servir para transsignificar conceitos do leitor sobre os papéis sociais culturalmente estabelecidos e fazer com que ocorra uma conscientização sobre as estratégias de manutenção do poder patriarcal, que preveem que as atribuições de gênero se mantenham naturalizadas de forma a manter apagadas e silenciadas as identidades que fujam aos padrões ditados pela norma. A personagem Moira (amiga de Offred antes do golpe) aparece em alguns capitulos e é a personificação desse apagamento. Ela assumia, antes do golpe, uma identidade lésbica e feminista militante. Após o golpe, foi obrigada a virar handmaid. Tentou fugir do centro de treinamento algumas vezes até quase conseguir fugir da República de Gilead, quando foi pega na divisa. Pensou que fosse ser assassinada e colocada no muro, pois o Estado disciplinar 
previa que quem fugisse às normas seria enforcado e exposto no muro para que servisse de exemplo. No entanto, foi enviada para uma espécie de clube, o qual apenas os comandantes e visitantes (homens) de outras repúblicas poderiam frequentar. Moira foi então obrigada a se prostituir - mas sem ganhar nada em troca, virou escrava sexual. O comandante para o qual Offred servia de handmaid a levou uma noite a este clube, ilegalmente, como forma de ostentar seu poder.

Offred conseguiu conversar por alguns minutos com Moira, quando se surpreendeu com seu apagamento. A amiga parecia uma espécie de zumbi, integrada à situação e desprendida das suas identidades e desejos anteriores:

'Então aqui estou. Eles dão até creme para o rosto. Você deveria dar um jeito de vir para cá. Você ainda teria dois ou três anos até ficar acabada e eles te mandarem para o cemitério. A comida não é ruim e há bebidas e drogas se você quiser... E só trabalhamos à noite'.

'Moira', eu disse. 'Você não quis dizer isso'. Ela está me assustando, porque o que ouço na voz dela é indiferença, falta de vontade. Eles fizeram algo com ela então, tiraram algo dela - o quê? que era essencial para ela (ATWOOD, 1985, p.261- tradução livre).

O apagamento dos desejos e das identidades marginalizadas culturalmente na narrativa se dá de forma extrema e pode contribuir para que olhemos para as situações que 
se processam culturalmente no mundo que temos como real. Podemos questionar: até que ponto os discursos que se processam como normativos na nossa cultura não apagam e submetem indivíduos a situações como a de Moira? Quais os desdobramentos emocionais desse apagamento?

Há narrativas que apresentam situações extremamente traumáticas ou distópicas para personagens femininas e que não mostram os desdobramentos dessas situações. Um exemplo desse tipo de acontecimento é a restrição da personagem feminina às suas funções biológicas em uma narrativa televisiva extremamente conhecida e bem cotada entre fãs de ficção científica, Star Trek: the Next Generation. A objetificação da personagem feminina é exacerbada pela não demonstração das consequências dessa experiência traumática, conforme assinala Anita Sarkeesian (2011):

Deanna Troi de Star Trek: the next generation é talvez a exacerbação do estereótipo da gravidez mística, pois o corpo e a mente da personagem são regularmente ocupados, emprestados, violados e invadidos por seres alienígenas. Durante a segunda temporada, no episódio 'The Child', a Conselheira Troi é engravidada por uma bola voadora de energia espacial de um feto alienígena que cresce virtuosamente. Imagine se descobrir grávida, dar à luz 36 horas depois, criar a criança em um dia, e então a criança morre - ou, neste caso, desaparece. Não vemos Troi lidando com 
as ramificações de longo prazo desse evento tão traumático, e a experiência nunca é mencionada novamente durante a série (2011, 3' 15” - grifo da autora - tradução livre).

Essa desconsideração das ramificações do evento traumático perpetua a imagem da mulher como "vaso de receber" e como objeto sem subjetividade a ser usado com fins específicos. Essa questão remete ao terceiro recurso que proponho para uma leitura transsignificativa: observar se, na narrativa, aparecem os desdobramentos emocionais de traumas ou experiências negativas vividas pelas personagens femininas ou representantes de grupos marginalizados pelo imaginário coletivo.

A narrativa Ascensão e queda de Robhéa, manequim \& robô, de Caio Fernando Abreu (2001), apresenta como pano de fundo uma "peste tecnológica", responsável pela mutação da carne humana em metal, resultando na robotização dos contaminados. Esses humanos-robôs morrem enferrujados por não terem disponiveis para si métodos de lubrificação. Não obtêm nenhum tipo de auxílio, já que o chamado Poder, grupo representante dos homens "normais", desejava exterminá-los. Autores que optam por uma leitura materialista da obra, como Gomes (2009), propõem que o Poder, na narrativa, representaria o Estado. No entanto, prefiro ler esse "Poder" como todas as estruturas de manutenção do status normativo da cultura e que colaboram para 
a banalização das verdades do imaginário coletivo e impedem a desterritorialização desses conceitos. O "Poder", no conto de Abreu, não se manifesta em direção única, mas é composto de relações complexas que são naturalizadas de forma a excluir o que é diferente do proposto pela normatização cultural. Ele promove o exterminio dos "contaminados":

Não foi dificil contê-los. No sétimo dia morriam pelas esquinas em estilhaços metálicos e ruídos de ferragens. A epidemia se alastrara de tal modo que se tornara muito fácil surpreendê-los. Os policiais nem mais se preocupavam em armar ciladas, disfarçando-se de civis para poderem acompanhar e prevenir a evolução da peste. Os contaminados - assim haviam sido chamados pelo Poder - não suportavam o processo por mais de uma semana (ABREU, 2001, p. 44).

Um pequeno grupo dos robôs sobreviventes, marginalizados socialmente, passa a viver clandestinamente nos esgotos até ser descoberto e exterminado. No entanto, uma robô sobrevive, e os manipuladores do Poder passam a usá-la como modelo da nova tendência normativa, de forma a lucrarem com sua imagem:

A rua suspeita foi cercada, os policiais derrubaram as portas com metralhadoras e encurralaram os contaminados contra uma parede úmida onde, com fortes jatos d'água, conseguiram enferrujar lentamente suas articulações. 
Morreram todos, da mesma maneira que os seus precursores - a exceção de uma jovem inteiramente mecanizada, com grandes olhos em vidro rosa e magníficas pernas de aço. [...] seu fim seria desgraçadamente o mesmo de seus companheiros, se um famoso costureiro não tivesse se interessado por ela. Foi visitá-la na prisão e, por meio de vários e demorados contatos com figuras influentes, conseguiu libertá-la para mais tarde lançá-la como principal manequim de sua coleção de outono (ABREU, 2001, p. 48).

Robhéa, a robô sobrevivente, torna-se manequim e atriz de sucesso, mas é obrigada a assumir a identidade que a imaginação constituinte coletiva dita para ela. Robhéa então

[...] retirou-se para uma ilha deserta e inacessivel, onde viveu até o fim de seus dias. Comentou-se que seria homossexual, e fora obrigada pelos empresários a esconder esse terrível fato do grande público (ABREU, 2001, p. 48).

A supressão de sua identidade e de seus desejos pela sociedade é um acontecimento traumático que a leva a preferir o ostracismo ao sucesso, até não suportar mais sua posição:

Muitos anos depois, os jornais publicaram uma pequena nota comunicando que Robhéa, ex-manequim, ex-atriz de cinema e robô de sucesso 
em passadas décadas, suicidara-se em sua ilha deserta e inacessivel tomando um fatal banho de chuveiro (ABREU, 2001, p. 49).

Ao contrário do que ocorre com Deanna Troi, em Star Trek, as consequências da objetificação da personagem Robhéa são mostradas no conto de Abreu. Apesar de a personagem não apresentar voz narrativa no conto, a perspectiva irônica do narrador impulsiona uma desterritorialização dos programas de verdade normativos da cultura no processo de apreciação do conto.

Foram apresentados três recursos para a detecção de aspectos nas narrativas científico-ficcionais que podem contribuir para uma leitura transsignificativa e, consequentemente, corroborar a desterritorialização de conceitos preestabelecidos no plano extraliterário. $\mathrm{O}$ primeiro corresponde à utopia relativa ao aspecto a ser analisado - no caso em questão, a utopia de desgeneralização; o segundo traz a perspectiva da personagem marginalizada, colocada em primeiro plano; o terceiro explicita os desdobramentos de longo prazo decorrentes de experiências traumáticas das personagens. Como parte integrante das culturas, as narrativas literárias podem e devem trazer elementos que colaborem para o desmantelamento do status normativo da cultura e, desta forma, desterritorializar as estruturas de poder que marginalizam grupos identitários. 


\section{REFERÊNCIAS}

ABREU, Caio Fernando. Ascensão e queda de Robhéa, manequim \& robô. In:

O ovo

apunhalado. Porto Alegre: L\&PM, 2001.

ARENDT, Hannah. A condição humana. Tradução de Roberto Raposo. Rio de Janeiro: Forense Universitária, 2007.

ATWOOD, Margaret. The handmaid's tale. London: Vintage Books, 1985.

BRAIDOTTI, Rosi. Nomadic subjects: embodiment and sexual difference in contemporary Feminist Theory. New York: Columbia University Press, 1994.

DEL REY, Lester. Helen O'Loy. In: SILVERBERG, Robert (Ed.). The science fiction hall of fame. New York: Avon, 1971. (Publicado originalmente na revista Astounding Science Fiction, em 1938).

DELEUZE, Gilles; GUATTARI, Félix. Mil platôs: capitalismo e esquizofrenia. Tradução de Aurélio Guerra Neto; Célia Pinto Costa. Rio de Janeiro: Editora 34, 1995.

. O que é filosofia? Tradução de Bento Prado Jr.; Alberto Alonso Muñoz. São Paulo: Editora 34, 2001. 
FOUCAULT, Michel. Soberania e disciplina. In: Microfísica do poder. Tradução de Roberto Machado. Rio de Janeiro: Edições Graal, 1979.

GOMES, André Luiz. Os conflitos identitários em "Ascensão e queda de Robhéa, manequim \& robô". Revista Estação Literária, Londrina, v. 4, n. 3, p. 3-14, nov. 2009.

HOLLINGER, Veronica. Feminist Theory and Science Fiction. In: JAMES, Edward; MENDLESOHN, Farah. The Cambridge Companion to Science Fiction. Cambridge: Cambridge University Press, 2003.

INVASÃO do mundo - Battle L.A. Direção de Jonathan Liebesman. Produção de Jeffrey Chernov. Roteiro de Chris Bertolini. Los Angeles: Columbia Pictures, 2011.1 DVD (116 min), color.

LE GUIN, Ursula. The Left Hand of Darkness. London: Hachette Digital, 1969 (Kindle Edition).

MUMFORD, Lewis. História das utopias. Tradução de Isabel Donas Botto. Lisboa: Antígona, 2007.

RUSS, Joanna. The image of women in Science Fiction. In: KOPPELMAN, Susan (Org.). Images of women in fiction: feminist perspectives. Ohio: Bowling Green University Popular Press, 1973. 
SARKEESIAN, Anita. Tropes vs. Women: the mystical pregnancy. [S.1., s.n.], 2011. Disponivel em: <http: / /www.youtube.com/watch?v=0rhH_QGXtgQ>. Acesso em: 26 set. 2013.

SUVIN, Darko. Metamorphoses of Science Fiction: on the Poetics and History of a Literary Genre. New Haven: Yale University Press, 1979.

VEYNE, Paul. Acreditavam os gregos em seus mitos? Ensaio sobre a imaginação constituinte. Tradução de Horácio González; Milton Meira Nascimento. São Paulo: Brasiliense, 1984. 


\title{
"EU AMO ABEL COMO A MIM MESMO E O AMOR DE JESUS É O MESMO DENTRO DE NÓS": A DESSACRALIZAÇÃO DO DIVINO NA OBRA EM NOME DO DESEJO, DE JOÃO SILVÉRIO TREVISAN
}

\author{
Maria de Fátima Lopes Vieira Falcão ${ }^{1}$ \\ Flávio Pereira Camargo²
}

Voou para a água e nadou em direção aos magníficos cisnes. Estes viram-no e vieram ter com ele a toda a velocidade, agitando a plumagem.

-Vá, matem-me - disse o pobre patinho curvando a cabeça mesmo até à água enquanto esperava pelo fim. Mas o que é que viu ele refletido em baixo? Observou-se bem - já não era uma desajeitada ave feia e cinzenta. Era igual às orgulhosas aves brancas ali ao pé: era um cisne!

(ANDERSEN, 1945, p.78/79).

1 Bolsista da Capes e, atualmente, desenvolve pesquisa no Mestrado no Programa de Pós-Graduação em Letras: Ensino de Língua e Literatura, da Universidade Federal do Tocantins, sobre a obra de João Silvério Trevisan.

E-mail: <fatimafalcao@hotmail.com>.

2 Pós-doutor em Estudos Literários pela UFMG. Doutor em Literatura pela UnB. Doutor e Mestre em Letras e Linguística (Estudos Literários) pela UFG. Professor de Literatura Brasileira da UFT/Campus Universitário de Araguaína, atuando na graduação e no Programa de Pós-Graduação em Letras. E-mail: <camargolitera@gmail.com>. 
Segundo Wolfgang Popp, citado por José Carlos Barcellos (2006), Hans Christian Andersen, como escritor, idealizou através de seus personagens sua "experiência como homossexual", vista como "diferente e marginal", como seu personagem acima, "O Patinho Feio", por exemplo. Além disso, Popp (2006, p. 34) destaca que é preciso estar "sintonizado para ler de maneira coerente e metódica esses disfarces [para ser] capaz de decodificá-los de maneira plena", uma vez que não são tão explícitos, de fácil dedução em uma obra literária.

Se no passado muitos escritores camuflavam sua homossexualidade através de seus trabalhos literários, na atualidade, acontece exatamente o inverso. João Silvério Trevisan, autor de Em nome do desejo, vai abordar o homoerotismo de forma "densa, corajosa e emocionada", como Caio Fernando Abreu destaca na contracapa do livro. A obra é para toda categoria de leitor, principalmente para o adolescente em dúvida sobre a sua identidade sexual. Com certeza a leitura não apontará caminhos mais fáceis, contudo ajudará na construção da subjetividade daqueles que "descobrem-se amando contra a corrente. E, ainda que perplexos, amam (TREVISAN, 2001, p. 6).

Bem antes de adentrar na leitura da obra há o croqui de uma planta baixa do seminário onde a história se passa. Destaca-se a forma como é feita a separação dos internos: os menores e os maiores. Quando se adentra a "nave", a partir do esboço, pela alameda, do lado direito ficam os nichos dos meninos maiores, e à esquerda o dos 
menores. Tanto o campo de futebol quanto o galpão de recreio ficam do lado esquerdo, ou seja, a associação ao lado que se refere ao lúdico fica com as crianças menores; enquanto a capela, a horta, o galinheiro e o chiqueiro ficam do lado direito, em uma alusão à maturidade, à oração e ao trabalho.

No dormitório dos meninos maiores encontra-se o quarto do Reitor e no dormitório dos menores, o quarto do Diretor Espiritual. A sala da reitoria fica em frente ao corredor central, que dá acesso aos dois lados do seminário. A passagem proporciona uma visão bem abrangente de todo o prédio; com a leitura vai se percebendo que há um sistema hierárquico bem fundado para estabelecer a disciplina, além dos horários rígidos e dos malfadados Regulamentos, esses, por sua vez, sempre iniciados com letra maiúscula, como se personificassem uma entidade.

É sagaz a forma como é montada a narrativa na obra, em forma de perguntas e respostas, muito parecidas aos livretos que são modelados para o ensino do catecismo de crianças. Todavia, na obra de Trevisan, o narrador é astutamente irônico. O livro conta a história de amor de dois personagens, Tiquinho e Abel; desde a entrada de Tiquinho no seminário, ainda criança, pois ainda não usava cueca, "andar sem cuecas é contra o Regulamento" (TREVISAN, 2001, p. 58), seu primeiro susto quanto a sua sexualidade: "Alguma coisa saiu errada comigo" (TREVISAN, 2001, p. 59), quando se encantou por Abel, até a saída inesperada deste da instituição. 
A partir dessa explanação, iniciamos este trabalho afirmando que a obra de Trevisan abordaria o tema do homoerotismo. É importante fazer um breve comentário sobre essa questão, uma vez que homoerotismo tem sido "uma noção mais flexível e que descreve melhor a pluralidade das práticas ou desejos dos homens same-sex oriented", de acordo com Jurandir Costa (1992, p. 21). O autor segue acrescentando que o termo "exclui toda e qualquer alusão a doença, desvio, anormalidade, perversão etc., que acabaram por fazer parte do sentido da palavra homossexual". Mesmo porque Costa (1992, p. 23) lembra que "homem homossexual nada mais é que uma realidade linguística, e não uma realidade natural"; de modo que os termos "homossexualismo ou homossexual" estão completamente vinculados à discriminação e não dependem "da intenção do falante", pois a linguagem não é acerto de contas, mas "uma forma de vida, uma aparelhagem simbólica complexa por meio da qual lidamos com nossas circunstâncias ambientais" (COSTA, 1992, p. 25).

A substituição, por parte de muitos autores, da palavra "homossexualidade" por "homoerotismo", como salienta Barcellos (2006, p. 22), pode acarretar "perda politica", pois o termo homossexualismo estaria

[...] mais apto a formas de resistência [; todavia, esse autor diz que] em termos de crítica literária a abertura dada pelo conceito de homoerotismo é imprescindivel para qualquer trabalho 
que não se atenha exclusivamente a uma forma específica e bem delineada de relação ou identidade homoerótica,

ou seja, é muito mais abrangente com relação a outras identidades.

Quando se fala de um ambiente fechado, como o do seminário, na obra de Trevisan, onde há fortes relações entre pessoas do mesmo gênero, não podemos deixar de frisar sobre a homossociabilidade, que, segundo Eve Sedgwick (1985, p.1),

[...] é uma palavra ocasionalmente usada em História e nas Ciências Sociais, onde descreve ligações entre pessoas do mesmo sexo; [...] que pode ser caracterizada, como em nossa sociedade, por forte homofobia, medo e ódio contra homossexuais ${ }^{3}$.

É importante destacar que a homossociabilidade é uma prática que leva em consideração "os laços de solidariedade e colaboração, por um lado, ou de rivalidade e competição, por outro, entre os indivíduos que se identificam como pertencentes ao mesmo gênero", como explica Barcellos (2006, p. 23). Visto por essa perspectiva, o seminário é "um espaço de exclusão e, ao mesmo tempo, possibilidade

3 No original: "Homosocial" is a word occasionally used in history and the social sciences, where it describes social bonds between persons of the same sex: [...] which may, as in our society, be characterized by intense homophobia, fear and hatred of homosexuality” (tradução nossa). 
de existência da homossexualidade" (LOPES, 2002, p.129-130), que tanto pode provocar o distanciamento, como também estreitar as relações afetivas entre os seminaristas. Na obra Em nome do desejo, há uma demanda por identidade, pois, para cada aluno, há a solidão pelo corte familiar brusco e a necessidade de uma socialização forçada, hierarquizada por relações de poder com os superiores; a luta com o discurso bíblico e religioso para disciplinar os corpos; as injúrias por meio da linguagem; enfim, o seminário é o espaço da punição, da vigilância e da disciplina.

A nossa sociedade, predominantemente patriarcal, ainda tenta manter suas bases no binarismo ser homem ou ser mulher, embora ela tenha passado ao longo dos anos por radicais transformações históricas e sociais. As identidades diferentes dos padrões preestabelecidos são chamadas de "estranhas ou desviantes", segundo Kathryn Woodward (2000, p. 32); esta autora prossegue dizendo que "a forma como nós vivemos nossas identidades sexuais é mediada pelos significados culturais sobre a sexualidade que são produzidos por meio de sistemas dominantes de representação".

Percebe-se, na obra de Trevisan, uma competição dentro do seminário, e muitas vezes inglória, vez que há a necessidade de se autoafirmar, se impor, pois, a todo o momento, exige-se, dos meninos, diferentes performances, resultantes de técnicas disciplinares que têm como objetivo moldar as suas subjetividades, as suas práticas, os seus corpos e os 
seus desejos mais recônditos. De acordo com Tomaz Tadeu Silva (2000, p. 81):

A afirmação da identidade e a enunciação da diferença traduzem o desejo dos diferentes grupos sociais, assimetricamente situados, de garantir o acesso privilegiado aos bens sociais. A identidade e a diferença estão, pois, em estreita conexão com relações de poder. O poder de definir a identidade e de marcar a diferença não pode ser separado das relações mais amplas de poder. A identidade e a diferença não são, nunca, inocentes.

A propósito da hierarquia, os meninos convivem com um Diretor Espiritual, que "transpirava ternura de mãe" (TREVISAN, 2001, p. 85); com um Reitor, que "lembrava o porte ao mesmo tempo garboso e irrepreensivel de um potro de raça" (TREVISAN, 2001, p. 85); com um Prefeito de Disciplina e com os anjos. O Prefeito de Disciplina é a pessoa que faz valer as regras, além de determinar os castigos, é temido e substituído a cada seis meses; tem o costume de proteger seus "prediletos ou peixinhos". Por sua vez, os anjos são aqueles que recebiam os novatos e lhes "ensinavam pontos principais do Regulamento" (TREVISAN, 2001, p. 45). Já o Reitor e o Diretor Espiritual manipulam os meninos fazendo-os expor seus corpos nus, para verificação de higiene, em uma demonstração de "interesse" com os cuidados de limpeza de seus prepúcios, os dos garotos, entretanto 
"seus gestos profissionais não conseguiam ocultar intenções subjacentes que os alunos mais sensiveis captavam" (TREVISAN, 2001, p. 97).

Curiosa é a forma como os sacerdotes repudiam em público a homossexualidade, porém, nas suas instituições, longe das vistas do povo, eles articulam a própria identidade homossexual. Ellis Hanson (apud BARCELLOS, 2006, p. 89-90), ao discorrer sobre os homossexuais que se tornam sacerdotes, afirma que eles "se converteram a uma igreja cujo discurso oficial repudia o homoerotismo de forma tão veemente", e, ao mesmo tempo, ele responde dizendo que "a igreja pôde ser vista pelos decadentistas como um teatro para a articulação de desejo e das identidades homossexuais"; ou seja, na sociedade aberta, os prelados tendem a se esconder, como se estivessem em um “armário”. Já a igreja, com sua aura de acolher "homens corretos e pudicos", torna-se um espaço de apoio para a articulação das suas identidades, a dos sacerdotes, uma vez que ela, a igreja, na maioria das vezes, faz vista grossa para os abusos sexuais cometidos por alguns de seus membros.

Na obra Em nome do desejo, a identidade está ligada ao disciplinamento, e este tem como espaço o seminário, e cada um desses espaços, como escolas, conventos etc. têm sua politica de coerção e suas técnicas de disciplinamento. Essa politica de disciplina "fabrica assim corpos submissos e exercitados, corpos dóceis", segundo Michel Foucault (1987, p. 119). 
Este autor ainda nos lembra de que "durante séculos, as ordens religiosas foram mestras de disciplinas: eram os especialistas do tempo, grandes técnicos do ritmo e das atividades regulares" (FOUCAULT, 1987, p. 119). No romance em tela, os internos

[...] levantavam-se às 5 e meia, [...]. Às 6 horas iam todos para a capela, [...]. Às 7 e meia, desjejum no refeitório [...]. Às 8 horas, início das aulas, que duravam até $11: 55,[\ldots]$. Ao meio dia, almoço, [...]. Às 12:30 começavam os trabalho comunitários obrigatórios [...]. Às 13:30, primeiro horário de estudo, [...]. Às 14:30, recreio para lanche rápido (TREVISAN, 2001, p. 35).

Os espaços de sociabilidade repetem determinados tipos de comportamento, buscando uma "docilidade automática" e os "treinamentos indefinidamente progressivos", como salienta Foucault (1987, p. 142), têm como objetivos a produção de corpos automaticamente treinados para determinadas circunstâncias, e ficam longe de um comportamento naturalizado. Foucault (1987, p. 143) ainda nos lembra de que "o sucesso do poder disciplinar se deve sem dúvida ao uso de instrumentos simples: o olhar hierárquico, a sanção normalizadora e sua combinação num procedimento que lhe é específico". Técnicas de disciplina que podem ser observadas no romance de Trevisan, pois o Reitor e o Diretor Espiritual tinham seus métodos disciplinares: 
Quanto à masturbação, que continuava rigorosamente controlada, o Reitor assim se manifestava, em suas vistorias: 'Deixa eu ver os peitos. Eta, peito inchado. Masturbação demais, rapaz. Vê se toma jeito. Peito inchado em homem é feio'. Já o Diretor Espiritual era diferente: relacionava-se e cuidava dos seus Menores como se levitasse desde o início e os chamasse para o alto, consigo. Usava estratagemas poéticos: no caso da masturbação, amarrava fitinhas de várias cores no membro genital dos meninos mais reincidentes. As várias cores correspondiam à gravidade das fases masturbatórias. Para um controle que ele fazia pessoalmente e com rigor, obrigava os garotos a dar um nó na fitinha, a cada nova masturbação. Assim, acompanhava de perto a atividade pecaminosa dos pequenos, com muita imaginação (TREVISAN, 2001, p. 100).

Cada um dos internos é observado e, de acordo com o comportamento, recebe coimas (rezas, confissão). Mesmo o número de alunos sendo maior do que o de disciplinadores, todos os sujeitos (os alunos) estão em evidência, mesmo porque o poder é invisível, porém todos “os súditos têm que ser vistos" (FOUCAULT, 1987, p. 156). Sim, o poder é invisivel, contudo a disciplina está em todos os cômodos do seminário, pois pode acontecer em qualquer instituição com o intuito de treinar os corpos, o que Foucault define como corpos "dóceis". 
As sanções, como a confissão e os exames de consciência, são parâmetros usados, neste caso, no seminário, com o intuito de medirem os "pensamentos e, principalmente, suas atitudes (no caso dos internos), devendo elas ser 'coerentes' ou não com os valores morais socialmente estabelecidos", como destaca Cláudio Mendes (2006, p. 175). Neste sentido, conforme afirma Michel Foucault (1988, p. 70-71),

a confissão é um ritual de discurso onde o sujeito que fala coincide com o sujeito do enunciado; é, também, um ritual que se desenrola numa relação de poder, pois não se confessa sem a presença ao menos virtual de um parceiro, que não é simplesmente o interlocutor, mas a instância que requer a confissão, impõe-na, avalia-a e intervém para julgar, punir, perdoar [...]. [...] articula modificações intrínsecas: inocenta-o, resgata-o, purifica-o, livra -o de suas faltas, libera-o, prometelhe a salvação.

$\mathrm{O}$ personagem Tiquinho em alguns momentos começa a se afastar de seu mentor, o Diretor Espiritual, pois este insinua que a relação com Abel, amor de Tiquinho, deve ser cortada. Tiquinho não quer se ver em um imbróglio religioso, exatamente por temer o pecado, e, ao mesmo tempo, também não quer perder seu amor. A única solução é evitar seu superior, como um "mecanismo de defesa" (MENDES, 2006, p. 175).

Além disso, também existem as provo- 
cações, os escárnios para demarcar uma identidade que é degradada e depreciada. Os garotos como Tiquinho eram chamados de "mariquinha", eram humilhados no jogo do garrafão, "como um corredor polonês de lambadas por todos os lados" (TREVISAN, 2001, p. 49). A "turma dos humilhados", como era conhecida a de Tiquinho, também era chamada pelo nome de "bicharada". O próprio nome Tiquinho vem do pássaro Tico-Tico, que pode ser visto como alusão ao termo pejorativo atribuido aos homossexuais e perpetuado pela sociedade heteronormativa. Foucault (1998, p. 50) afirma que:

[...] o homossexual do século XIX torna-se uma personagem: um passado, uma história, uma infância, um caráter, uma forma de vida; [...] nada daquilo que ele é, no final das contas, escapa a sua sexualidade. Ela está presente nele todo: subjacente a todas as suas condutas [...]; inscrita sem pudor na sua face e no seu corpo já que é um segredo que se trai sempre.

Por sua vez, Judith Butler (2008, p. 39) afirma que "a matriz cultural por intermédio da qual a identidade de gênero se torna inteligivel exige que certos tipos de 'identidade' não possam 'existir"', ou seja, há o apagamento de certas identidades, da diferença (do outro). As agressões verbais são comuns e ininterruptas contra os gays, de modo que "paira como uma ameaça instalada em cada instante da vida so- 
cial, arriscando para alguns fazê-la bascular num futuro que eles consideram inimaginável e insuportável", de acordo com Didier Eribon (2008, p. 64). Assim, para muitos homossexuais, ficar no armário é uma estratégia de sobrevivência.

A partir dessas marcações linguísticas, tais como "mariquinha" e "bicharada", como lemos na narrativa de Trevisan, reitera-se a naturalização do essencialismo, ou seja, as pessoas pertencem a "um determinado grupo identitário", e por isso a "identidade é vista como fixa e imutável", segundo Woodward (2000, p. 13), tentando moldar os corpos e os sujeitos que são diferentes dessa matriz. E essa distinção entre identidades ocorre justamente através e por meio da linguagem, pois é através dela que nós nomeamos o outro, atribuindo a ele/ela uma identidade linguística e cultural, pois o conceito de representação social do outro e, principalmente, da diferença que lhe é constitutiva é (de)marcada pelo discurso, pelo modo como o eu representa o outro. Enfim, trata-se de um processo de alteridade, com suas implicações para a compreensão da diferença do outro, que precisa ser questionado e problematizado por meio de um exercício de hermenêutica.

Esse discurso hostil em relação ao outro é depreciativo e é evidente que deixa marcas na sua subjetividade para sempre, pois não pertencendo a uma sexualidade hegemônica, esse sujeito é visto como uma "anomalia", portanto, passivel de correção, de uma sanção. A 
brincadeira do garrafão entre os meninos no seminário dissimula essa correção e a sanção contra aqueles que são vistos como corpos indisciplinados, como seres abjetos. Julia Kristeva (1982, p. 4), ao se referir ao conceito de abjeto e abjeção afirma o seguinte "Não é a falta de limpeza ou saúde que causa abjeção, mas o que perturba a identidade, o sistema, a ordem. $\mathrm{O}$ que não respeita limites, posições, regras. $\mathrm{O}$ que está entre, o ambíguo, o compósito" 2 .

Outra autora que percebe a referência ao corpo como algo abjeto é Judith Butler (2010, p.161) ao afirmar que esses sujeitos considerados abjetos são seres "que não parecem apropriadamente generificados; é sua própria humanidade que se torna questionada". Neste sentido, no seminário, os meninos mais fortes se aproveitam da agressividade da "brincadeira" para expor sua masculinidade e provar sua hierarquia e sua raiva e, assim, impor a dor física àqueles que são julgados como mais fracos, àqueles que borram as fronteiras entre os gêneros. Segundo Foucault (1987, p. 119), essa "coerção disciplinar estabelece no corpo o elo coercitivo entre uma aptidão aumentada e uma dominação acentuada", que deixa marcas profundas na subjetividade dos sujeitos.

O narrador de Em nome do desejo brinca com o discurso religioso, como em uma desconstrução por meio da paródia, pois, como foi

\footnotetext{
4 No original: "It is thus not lack of cleanliness or health that causes abjection but what disturbs identity, system, order. What does not respect borders, positions, rules. The in-between, the ambiguous, the composite” (tradução nossa).
} 
dito anteriormente, a estrutura composicional da narrativa lembra os livretos de catecismo. Contudo, a obra toma um caminho discursivo completamente adverso, que se converte em local de enfrentamento discursivo, fazendo evasivas a seu bel prazer: "Mãe, mãe, por que me abandonaste?” (TREVISAN, 2001, p. 48); "Por pensamentos, palavras e, às vezes, por obras" (TREVISAN, 2001, p. 64); "Ministério da Santíssima Paixão" (TREVISAN, 2001, p. 159); “Na capela, respirava ao mesmo tempo sacralidade e sensualidade" (TREVISAN, 2001, p. 127); como uma forma de dessacralizar o discurso religioso.

Para Mircea Eliade (1992, p. 14), essa

[...] dessacralização caracteriza a experiência total do homem não religioso das sociedades modernas, o qual, por essa razão, sente uma dificuldade cada vez maior em reencontrar as dimensões existenciais do homem religioso das sociedades arcaicas.

É como se o sagrado fosse um obstáculo à liberdade do homem.

Percebe-se, na narrativa, que há um conflito em Tiquinho por não entender o porquê seria considerado proibido um homem dizer "eu te amo para um outro homem" (TREVISAN, 2001, p. 124), se no próprio Evangelho de São João ele lê isso, e sentir-se tão atraído pela "imagem de São João com a cabeça recostada no peito de Jesus" (TREVISAN, 2001, p.124), como em uma humanização e erotização do 
divino. Contudo, ele, o personagem, começa a fazer sua própria interpretação quando passa "a chorar de intensa felicidade, com a cabeça recostada no peito cheiroso de Jesus" (TREVISAN, 2001, p.159).

É importante dizer que esse "peito cheiroso" não é propriamente o de Jesus, mas o Jesus de Tiquinho, Abel, seu grande amor, como o amor de São João por Jesus no Evangelho. Há um emaranhado de imagens, crenças, religiosidade, questionamentos, e ingenuidade por parte do personagem que acaba por deixá -lo à mercê de suas próprias conclusões. Tudo o que Tiquinho lê e vê é como uma bênção para sua afeição por Abel.

Mesmo contra os alertas do Diretor Espiritual, as gozações dos colegas e todos os encontros às escondidas entre eles, Tiquinho via seu amor como sagrado e isso lhe bastava. O corpo de Tiquinho estava falando, um corpo que exala desejo, carente do corpo do outro. De acordo com Foucault (1988, p. 50), a sexualidade está "subjacente a todas as suas condutas" (a dos homossexuais), já que a sexualidade "é um segredo que trai sempre" (TREVISAN, 2001): "tratava-se de uma mescla de atração, curiosidade, veneração e necessidade diabolicamente alheia ao seu controle" (p. 179). Esta veneração, ou amor ingênuo do personagem Tiquinho, é demonstrada, em um poema de São João da Cruz, escrito em seu diário:

Como o amado no amante, um no outro residia.

E tal amor que os une 
no mesmo coincidia, pois um igualava o outro em intensidade e valia. Três pessoas e um amado entre todos os três havia, um só amor nelas todas e um só amante as unia, em tão inefável nó que dizê-lo não se sabia. Era portanto infinito o amor que as fundia e de ser tão uno o amor, tanto mais amor havia (TREVISAN, 2001, p. 164-165).

Assim, podemos ter uma ideia da extensão do raciocínio de Tiquinho para sua relação com Abel e com Jesus: "Eu amo Abel como a mim mesmo e o amor de Jesus é o mesmo dentro de nós" (TREVISAN, 2001, p. 165). Essa relação dos três é muito significativa para Tiquinho. É a Santíssima Trindade personificada em uma imaginação juvenil que corrobora o momento de paixão do protagonista, além disso, mostra a dimensão do amor de Tiquinho por Abel, que beira o divino para aquele. Mas quem pode julgá-lo? Principalmente envolto em um espaço inebriado de sentimentos comparados ao amor bíblico e às inúmeras proibições, sua imaginação e sua sexualidade afloram dentro de um âmbito completamente passional e existencial.

"Cada um de nós ainda não é o que é, tem de esforçar-se por chegar a ser", diz João Guimarães Rosa, citado por Adélia Meneses (2010, p. 95). Esta frase expõe e revela ao leitor muito 
do personagem Tiquinho. Ele foi apartado da mãe, achou-se diferente por amar alguém do mesmo sexo, estava em um ambiente hostil à sua identidade, lutando tanto espiritualmente com suas crenças quanto exteriormente contra os preconceitos advindos de seu desejo por Abel. Além disso, ele percebe que "Abel tinha outros interesses vitais" (TREVISAN, 2001, p. 187), ficando, portanto, em segundo plano na vida daquele que ama.

Tiquinho tinha uma sensibilidade notável para a música clássica, como as de Beethoven, Stravinsky, Schubert etc., mas era Rachmaninov que, com seu Concerto $N^{o} 2$ para piano $e$ orquestra, o aderia a Abel de uma forma particular. O compositor escreveu aquele concerto a partir da insistência de um médico e, depois de tanto tempo, "aquele médico levara o compositor russo a exprimir com perfeição o amor indescritivel de dois rapazinhos brasileiros, eles mesmos" (TREVISAN, 2001, p. 175).

Além de o concerto proporcionar certa alegria a Tiquinho, também lhe concedia uma "sensação trágica do fim do amor" (TREVISAN, 2001, p. 175) entre ele e Abel. Uma sinfonia que é repleta de instrumentos de corda como violinos, violas e violoncelos, que conduzem o ouvinte a sentimentos fortes e ao arrebatamento do espírito. Segundo Eribon (2008, p. 46), a cultura, "no sentido amplo, e o gosto com tanta frequência evocado pelas divas, as estrelas do cinema, a imprensa, a literatura, os livros, as artes", ou seja, esses deleites mais refinados e elegantes eram muito apre- 
ciados pelos garotos chamados "afeminados", e passavam despercebidos pelos componentes da "brincadeira do garrafão", por exemplo.

Em certo momento da narrativa, a relação entre os dois jovens começa a degringolar: "A amizade particular entre Tiquinho e Abel já fazia parte do repertório de fofocas prediletas da comunidade" (TREVISAN, 2001, p. 196). O Reitor, por sua vez, lembrava que "amizades particulares continuarão rigorosamente proibidas nesta casa feita para ideais mais nobres" (TREVISAN, 2001, p.197). E "o casal fenomenal" (TREVISAN, 2001, p.196), como eles eram denominados pelos colegas, jogava uma partida de vôlei quando Abel chamou Tiquinho de "frouxo" (TREVISAN, 2001, p. 212). Eis o fogo da inquisição.

O Mistério da Paixão de Tiquinho culminará com uma forte transformação de seu caráter, um garoto tímido, "um tiquinho de gente" (TREVISAN, 2001, p. 30), como diz o narrador, para lidar com a vingança e o remorso, dois sentimentos febris, de uma vez só. São fases que Tiquinho teve de passar na sua via dolorosa para se individualizar. Pode não ter sido da melhor maneira, contudo, como diz Meneses (2010, p. 95), "o ser humano que tem que lutar para ser o que, fundamentalmente, é".

Implacavelmente, o tempo passa e a "tudo consome e devora", como lembram Carlos Silva e Débora Silva (2001, p. 28). Tiquinho agora já é um adulto, está de volta ao antigo seminário que se transformara em um orfanato. Se no início da narrativa, o protagonista per- 
gunta "por quais motivos eu quis voltar" (TREVISAN, 2001, p. 14), já no final indaga a si mesmo: "Quem me procuraria, neste lugar? Abel Rebebel, repete o irmão porteiro, de modo neutro" (TREVISAN, 2001, p. 232).

Denilson Lopes (2002, p. 130) afirma que Em nome do desejo é uma narrativa "sobrecarregada de tons barroquizantes". De fato, há o amor, os desejos, o fervor religioso, as taras e os corpos em movimentos constantes, em uma narrativa que conduz a imagens calientes, cores e sons fortes, pois "todo barroco complica, entretece e dilata”, segundo Fábio Andrade (2003, p. 14). O crânio, em forma de vaso, no primeiro e no último capítulo, marca as transmutações pelas quais o personagem Tiquinho passou. Na Alquimia, o crânio é como um momento mori, um emblema da operação de mortificação, segundo Regina Carvalho e Amanda Silva (2003), ou seja, Tiquinho era "um ser anestesiado" (TREVISAN, 2001, p. 229), como o narrador o descreve.

\section{Considerações finais}

Tzvetan Todorov (2010, p. 77) nos lembra de algo muito precioso ao afirmar que "a realidade que a literatura aspira compreender é, simplesmente (mas, ao mesmo tempo, nada é assim tão complexo), a experiência humana". Nós conhecemos o mundo vivendo e muitas vezes nos perguntamos: por que é que tal situação está me acontecendo? Por que eu? Não 
é nada pessoal, nós estamos no mundo para descobrir o que o mundo nos coloca a nossa frente. Nesse sentido, Em nome do desejo, de João Silvério Trevisan, é intrépida, é uma "revelação do mundo, ela pode também, em seu percurso, nos transformar a cada um de nós a partir de dentro" (TODOROV, 2010, p. 76).

Minorias que foram, ou ainda continuam marginalizadas, perseguidas, não podem "abrir mão da literatura", porque ela é "um instrumento precioso de conscientização e resistência ao monologismo inerente ao discurso do poder hegemônico" (BARCELLOS, 2006, p. 47). Por isso, acreditamos que a literatura produzida por Trevisan tem tanto o poder de que fala Todorov quanto o objetivo que Barcellos ressalta ao se referir a uma obra literária. Além disso, falar sobre homoerotismo de uma forma não hipócrita é ter senso de humanidade, é saber que há leitores que querem se emocionar e se identificar com a obra literária.

Quantos garotos não se questionam, têm dúvidas, vivem os mesmos conflitos que Tiquinho? Não é com a imposição de uma herança patriarcal, de um dualismo entre o feminino e o masculino, de padrões de comportamento da sociedade atual que resolveremos certas questões consideradas polêmicas pela sociedade. Apenas para começar, o problema, na verdade, não precisaria existir, porque somos nós que estamos impondo nomenclaturas sobre as pessoas que amamos, ou ditando para os outros como eles devem se comportar ou escolher a quem amar. 
Concordamos, portanto, com a afirmação do personagem "Teddy", de Salinger (apud COSTA, 1992, p. 14), sobre a capacidade de os humanos amarem uns aos outros:

\begin{abstract}
Acho que eles não são capazes de nos amar como nós somos. Parecem incapazes de nos amar a menos que consigam ficar mudando a gente um pouquinho. Eles amam os motivos que têm para nos amar tanto quanto amam a nós.
\end{abstract}

Somos plurais, pois esta é a condição do ser humano, "sem que ninguém seja exatamente igual a qualquer pessoa que tenha existido, exista, ou venha a existir", afirma sabiamente Hannah Arendt (2009, p. 16). 


\section{REFERÊNCIAS}

ANDERSEN, Hans Christian. O Patinho Feio. In: Andersen's Fairy Tales. New York: Grosset and Dunlap Publishers, 1945.

ANDRADE, Fábio Cavalcante. Ordem sinuosa: Barroco em Avalovara. [S.1., 2003]. Disponivel em: <http://www.liber.ufpe.br/teses / arquivo/20030714180142.pdf>. Acesso em: 7 jul. 2013.

ARENDT, Hannah. A condição humana. Tradução de Roberto Raposo. Rio de Janeiro: Forense Universitária, 2009.

BARCELLOS, José Carlos. Literatura e homoerotismo masculino: perspectivas teóricometodológicas e práticas críticas. In:

Literatura e homoerotismo em questão. Rio de Janeiro: Dialogarts, 2006.

BUTLER, Judith. Problemas de gênero: feminismo e subversão da identidade. Tradução de Renato Aguiar. Rio de Janeiro: Civilização Brasileira, 2008.

. Corpos que pesam: sobre os limites discursivos do sexo. In: LOURO, Guacira Lopes (Org.). O corpo educado: pedagogias da sexualidade. Belo Horizonte: Autêntica, 2010. 
CARVAlHO, Regina S.; SILVA, Amanda C. S. Estórias de Harry Potter: um catalisador para o estudo da Alquimia. Revista Ponto de Vista, [Viçosa], n. 5, p. 113-125, 2003. Disponível em: <http://www.coluni.ufv.br/revista/docs/volume05/estorias.pdf>. Acesso em: 12 maio 2013.

COSTA, Jurandir Freire. A inocência e o vício: estudos sobre o homoerotismo. Rio de Janeiro: Relume-Dumará, 1992.

ELIADE, Mircea. O sagrado e o profano. Tradução de Rogério Fernandes. São Paulo: Martins Fontes, 1992.

ERIBON, Didier. Reflexões sobre a questão gay. Tradução de Procópio Abreu.Rio de Janeiro: Companhia de Freud, 2008.

FOUCAULT, Michel. Vigiar e punir: nascimento da prisão. Tradução de Raquel Ramalhete. Petrópolis: Vozes, 1987.

. História da sexualidade I: a vontade de saber. Tradução de Maria Thereza da Costa Albuquerque, J. A. Guilhon Albuquerque. Rio de Janeiro: Graal, 1988.

LOPES, Denilson. O homem que gostava de rapazes e outros ensaios. Rio de Janeiro: Aeroplano, 2002. 
MENDES, Cláudio Lúcio. O corpo em Foucault: superficie de disciplinamento e governo. Revista de Ciências Humanas, Florianópolis, n. 39, p. 167-181, abr. 2006.

MENESES, Adélia B. Cores de rosa. Cotia: Ateliê, 2010.

SEDGWICK, Eve K. Between men: English Literature and Male Homosocial Desire. New York: Columbia University Press, 1985.

SILVA, Carlos Augusto Moraes; SILVA, Débora Cristina Santos. Poéticas intermédia: as interfaces do amor. In: CAMARGO, Flávio Pereira; CARDOSO, João Batista (Org.). Percursos da narrativa brasileira contemporânea. Goiânia: Ed. da PUC/GO, 2011. v. 2.

SILVA, Tomaz Tadeu. A produção social da identidade e da diferença. In: . (Org.). Identidade e diferença: a perspectiva dos estudos culturais. Petrópolis: Vozes, 2000.

TODOROV, Tzvetan. A literatura em perigo. Tradução de Caio Meira. Rio de Janeiro: DIFEL, 2010.

TREVISAN, João Silvério. Em nome do desejo. Rio de Janeiro: Record, 2001.

WOODWARD, Kathryn. Identidade e diferença: uma introdução teórica e conceitual. In: SILVA, Tomaz Tadeu (Org.). Identidade e diferença: a perspectiva dos estudos culturais. Petrópolis: Vozes, 2000. 


\title{
OS SOLTEIRÕES: DENTRO OU FORA DO ARMÁRIO?
}

\author{
Micaela Sá da Silveira ${ }^{1}$ \\ Antonio de Pádua Dias da Silva²
}

\section{Olhando por entre as brechas}

A família reunida na sala. Os amigos que se encontram por um chamado especial. Uma aula na faculdade. Uma festa em que o pai chega de repente. Um telefonema pedindo explicações. Uma carta que denuncia. Essas são algumas situações em que os sujeitos são postos - ou expostos - para falar de si, para esclarecerem à sociedade, aos parentes, amigos, esposas e maridos: o que desejam, afinal?

Situações como essas são constantes na sociedade e representadas na literatura, tornando assim a categoria do "armário" passível de questionamentos: O que é o "armário"? Por que os sujeitos precisam sair do "armário"? Por que esconder-se em um "armário"?

1 Graduada em Letras pelas Universidade Estadual da Paraíba. Mestra em Literatura e Interculturalidade pela mesma Instituição. E-mail: <micaelauep@hotmail.com>.

2 Professor Doutor do Departamento de Letras e Artes da UEPB e do Programa de Pós-Graduação em Literatura e Interculturalidade da mesma Instituição.

E-mail:<magister.padua@hotmail.com>. 
A quem pertence esse esconderijo? Para quê gritar ao mundo quem e quais são os nossos objetos de desejo? O que vem a ser assumir-se e por que temos de fazê-lo?

Diante de tantas inquietações, e claramente estimulados pela discussão apresentada por Eve Sedgwick (2007), no texto Epistemologia do armário, em que a autora nos permite (re)pensar esse espaço, no qual muitos sujeitos homoeroticamente inclinados são colocados ou do qual são retirados, além de refletir sobre os limites do público e do privado numa relação entre pessoas do mesmo sexo, debruçamo-nos sobre a obra de Gasparino Damata, intitulada Os solteirões (1975), a fim de problematizar esse "armário", levando em consideração o limiar entre estar/permanecer/sair deste lugar, para os personagens do conto.

Tomamos como objeto de estudo a obra damatiana, por colocar em evidência a possibilidade das múltiplas masculinidades para os sujeitos que mantêm relações homoeróticas. A discussão teórica que subsidia as masculinidades, no plural, foi embasada nos apontamentos de Elizabeth Badinter (1993) e Sócrates Nolasco (1993, 1997), tendo-se em vista que esses teóricos apresentam questionamentos acerca da relação do que é ser um homem, de como é/ foi construído esse sujeito nos vários contextos históricos, social e cultural. Igualmente, os estudos das categorias binárias como uma invenção, apresentados por Katz (1996), foram de suma importância para o debate sobre as relações hetero (superior) versus homo (inferior), 
que, muitas vezes, atuam como obstáculo para que os homens se entreguem aos desejos homoeróticos.

\section{Adentrando ou saindo dos possiveis "armários"?}

Entabular uma discussão em torno do "armário", considerando a efetiva visibilidade que as chamadas minorias vêm ganhando com o passar do tempo, requer pensar primeiramente: de qual "armário" estamos falando? A que objeto essa metáfora está se referindo? Comecemos a pensar que há, no minimo, duas direções para tal metáfora: a) popularmente costumou-se afirmar que os sujeitos inclinados homoeroticamente e que o declaravam, perante a sociedade o desejo por seu igual, estavam saindo do "armário", ou seja, estes indivíduos não escondiam a quem seu desejo "proibido" estava direcionado; b) o "armário", enquanto dispositivo político, do qual as multidões de minorias ${ }^{3}$ precisam sair, para que tenham uma representação social.

Buscando compreender as possibilidades de interpretação para a metáfora apresentada por Sedgwick (2007), encontramos na obra de Damata um campo proficuo para ampliar tal discussão. Os Solteirões (1975) apresenta os

3 Fazemos referência ao estudo de Beatriz Preciado (2011), no qual as minorias são apresentadas como multidões que se aglomeram nas diferenças, no direito de ser o que não se nomeia, ou simplesmente como uma multidão Queer. "As minorias sexuais tornam-se multidões. 0 monstro sexual que tem por nome multidão torna-se queer” (PRECIADO, 2011, p. 14). 
modos pelos quais os sujeitos masculinos se relacionam com a possibilidade do "armário", algumas vezes diretamente, outras vezes através da imposição ou necessidade de "revelarse", apresentando o assumir-se como objeto de debate dentro do núcleo a que pertencem os personagens. Nos contos de Damata, o "armário" está inserido nas relações entre os michês $^{4}$ com idades e posições sociais diferentes e que possuem desejo homoerótico manifestado ora em relacionamento mais duradouro, ora em relações de amor e ciúme, ou mesmo no desejo carnal, por exemplo.

Vamos aos contos. Em "Paraíba", há um diálogo entre dois rapazes: o narrador personagem, que relata sua saída da Paraíba para morar na cidade do Rio de Janeiro e sua experiência no cinema de "pegação"; e seu interlocutor, Seu Zé Orlando, que, no decorrer do texto, não apresenta nenhuma opinião, apenas ouve o narrador e partilha com ele as mesmas experiências de mudança de cidade e de frequentar o mesmo cinema. Percebemos que tanto o narrador personagem - caracterizado pela ambivalência de

40 conceito de michê que adotamos baseia-se nas concepções apresentadas por Perlongher (1987): a) nomeando o ato de prostituir-se, desenvolvido por qualquer sujeito; b) a prostituição como sendo efetivada por um homem másculo, que em seu estereótipo prevalece a virilidade. Salientemos que, na obra em análise, os michês nem são prostitutos, nem são másculos viris, conforme apontam os desdobramentos do conceito de Perlongher. Nos contos, a negociação está relacionada com a compra/paga do afeto e não apresentam os personagens como sendo efeminados ou puramente viris. 0 que temos são homens comuns que mantêm relações com outros homens. A diferença está, muitas vezes, na idade e/ou na condição financeira. 
sua masculinidade, como discutimos em outro momento (SILVEIRA, 2012) - quanto Seu Zé Orlando, não são gays, nem adotam tal masculinidade e, por isso, não teriam motivos para saírem do "armário" e expor algo que eles não são. Mesmo mantendo relações sexuais e afetivas com outros iguais, isso não os torna sujeitos inclinados homoeroticamente, se levarmos em consideração que só pode assumir-se gay, se o desejo homo for subjetivado pelo sujeito.

É interessante perceber que os personagens afirmam, constantemente, serem "de mulher", ou seja, o discurso deles é que o "negócio" realizado é para fins profissionais e que, na verdade, preconizam a relação com mulheres, embora pouco efetivada devido ao alto custo para mantê-las, pois "mulher é luxo. E luxo só rico é que pode ter" (DAMATA, 1975, p. 7). Neste sentido, justifica-se o fato desses personagens não assumirem nenhuma identidade gay, pois não se reconhecem dessa forma e sim como homens que frequentam o cinema e sentem-se bem: "se quisesse viver disso, podia até deixar de trabalhar, hoje mesmo" (DAMATA, 1975, p. 11), apontando o "negócio do michê"5 como uma fonte de renda.

Social e culturalmente, há uma ideia de que qualquer desejo - afetivo ou sexual - direcionado para seu igual é expressão de um sujeito gay, mas acreditamos que as categorias heterossexuais e homossexuais são, na verdade, imposições criadas por grupos hegemônicos, vislumbrando

5 Expressão utilizada por Perlongher (1987) e homônima ao título do livro. 
enquadrar as multidões de minorias para assim estigmatizá-las. Diante disso, nos questionamos: afinal, o que define o sujeito ser ou não gay? Sedgwick (2007) refere-se ao sujeito gay como sendo aquele que assume sua identidade e carrega as consequências que isso traz:

[...] quão problemático no presente é
o conceito mesmo de identidade gay e
também quão intensa é a resistência
a ela e o quanto a autoridade sobre
sua definição se distanciou da própria
pessoa gay - ele ou ela (SEDGWICK,
2007 , p. 38 ).

Ainda no conto "Paraíba", percebe-se que o narrador personagem não simpatiza, nem se sente atraído pelos sujeitos que são assumidos como gays e efeminados, que estão fora do "armário". O desinteresse do personagem fica claro ao afirmar que "não costumo dar atenção a essas bichas escandalosas, que ficam para cima e para baixo e que falam o tempo todo" (DAMATA, 1975, p. 11).

Em outros contos, percebemos a evidência dessa aversão dos sujeitos homoeroticamente inclinados para com os sujeitos que estão fora do "armário", bem como a preservação que estes personagens têm quanto à sexualidade. No conto $A$ desforra, o que temos no enredo é Ferreira, um dentista que busca vingar-se do seu "caso", por causa de uma traição. O seu "rapaz" o traiu com uma mulher, mas voltou a procurá-lo, quando ela o trocou por outra mulher. É interessante perceber que o dentista 
protege sua identidade e, em seu ambiente de trabalho, por exemplo, não há "nada de exageros, de decoração afrescalhada, porque Ferreira, ao contrário de alguns companheiros, evitava ao máximo tudo que pudesse denunciá-lo, bichices desnecessárias, como costumava dizer" (DAMATA, 1975, p. 132) e, ainda, é bastante enfático no que se refere à exposição pessoal ou saída do "armário" "- 'Detesto viadagem em público. Frescura, só em casa; ou dentro de quatro paredes"' (DAMATA, 1975, p. 132, grifo do autor).

Diante da postura do dentista, percebese que não há saída do "armário", pois entendemos que esse dispositivo só existirá em situação de risco, ou seja, perante a sociedade, que não aceita as relações que fogem do padrão por ela definido. Ora, se há "frescura só em casa", isso implica em dizer que apenas as pessoas que estão próximas - parentes e amigos - sabem das relações entre iguais vivenciadas por Ferreira.

A postura do dentista denota: o quanto é forte essa ideia de público e privado para os sujeitos homoeróticos, as situações que devem (será que devem?) ser mantidas em segredo, guardadas a "sete chaves", aquilo que a sociedade pode saber, ou que ela quer ouvir. Outro exemplo dessa situação está exposto no final do conto O voluntário que, segundo Howes (2010), narra uma história semelhante ao romance The Sergeant (1958), de Dennis Murphy: 
[...] um sargento militar apaixona-se por um praça sob seu comando. No romance americano, o soldado reage violentamente contra o assédio do sargento, que, totalmente isolado, acaba se suicidando. A novela de Damata tem o mesmo enredo, mas o desenvolvimento do tema é completamente diferente (HOWES, 2010, p.184).

O sargento do texto brasileiro considerava as bichas

[...] elementos indesejáveis - 'a vergonha da classe' [queria que] desaparecessem o mais depressa possivel do cenário. Não suportava gente de saia, mas também não tolerava bicha. Veado efeminado, que queria ser mulher a todo custo (DAMATA, 1975, p. 123 - grifo do autor).

O discurso apresentado por esse personagem afirma o pensamento da ambivalência do "armário", uma vez que, se os gays saem do "armário" e expõem seus desejos, performatizam sua masculinidade como bem desejam, são rechaçados pelos gays que não se assumem. Estes, popularmente conhecidos como enrustidos, são criticados pelos colegas que preferem revelar o segredo. Esse retrato da década de 1970, apresentado através dos contos, é uma realidade presente até os dias de hoje, fazendo com que os sujeitos homoeroticamente inclinados se encontrem entre os que saem dos "armários" e os enrustidos. 
Para além dos personagens que não saem do "armário", Damata também nos coloca diante de personagens que saem, ou melhor, são levados a sair do "armário", como em Fábula. Neste conto, é apresentada uma família tradicional, dentro dos padrões exigidos socialmente, no entanto, essa característica é apenas aparente, uma vez que no decorrer da leitura, o personagem, que mais protesta pela manutenção da moral e bons costumes, fora frustrado no que diz respeito ao afeto que sentiu pelo seu igual.

O enredo apresenta a experiência do "armário" vivenciada por Luciano, o filho caçula de Otávio, que acontece por meio de uma foto sua publicada em O Cruzeiro, "na qual aparecia com destaque no meio de um grupo de rapazes suspeitos no baile de carnaval da segunda-feira no Iate" (DAMATA, 1975, p. 164). Ao saber que essa foto já estava em domínio público, Luciano entra em pânico, uma vez que conhece o pai que tem: extremamente exigente, correto, digno, respeitador, que

[...] nunca levantara a mão para bater em filho, mas em questão de moral, qualquer coisa, por menor que fosse, capaz de atingir a honra da família, uma verdadeira fera, capaz de matar, de fazer qualquer loucura (DAMATA, 1975, p. 164-165).

Além disso, tinha um irmão mais velho que se comportava tal qual o pai e sabia-se preferido, por isso tomava atitudes semelhantes, 
para que o pai se orgulhasse dele. Diante dessa saída do "armário", o irmão expressava em seu rosto "um mapa ilhado de revolta e ódio" (DAMATA, 1975, p. 168). Diante de tal realidade, é compreensivel a reação de Luciano. O desmaio, o choro compulsivo ao encontrar o pai, que não nega o seu desagrado para com o filho: "- Eu preferia mil vezes vê-lo morto, meu filho, mil vezes morto a ter que ficar sabendo que você se tornou... também isso!" (DAMATA, 1975, p. 166).

É notório, diante das falas e da reação do pai, em um primeiro momento, o quanto tal revelação o incomodara e o quanto ele despreza esse tipo de comportamento. Essa atitude deixa clara uma questão: o legado de supremacia histórico e social que a heterossexualidade possui diante da homossexualidade. Um estudo relevante nesse aspecto é o de Katz (1996) que desconstrói a ideia de superioridade e apresenta a heterossexualidade como invenção criada para manter a homossexualidade como sua subordinada. Para ele, a heterossexualidade foi "construída bastante recentemente como o que é muito antigo: a heterossexualidade é uma tradição inventada" (KATZ, 1996, p. 183).

Nesse sentido, assumir uma posição diferente da imposta pela heterossexualidade é estar à espera de condenação. Segundo Segdwick,

[...] o "armário" pode ser entendido como um dispositivo de regulação da vida de gays e lésbicas que concerne, também, aos heterossexuais e seus 
privilégios de visibilidade e hegemonia de valores (SEGDWICK, 2007, p. 19 grifo nosso).

Ou seja, tanto sair do "armário" quanto manter-se nele está atrelado diretamente à relação binária do superior versus inferior, em que o favorecido sempre será o "superior", o detentor do poder, o dominante. Ao sair do "armário", "pede-se licença" para gritar ao mundo suas escolhas e, ao se manter no "armário", está escondendo da sociedade aquilo que desestabiliza a ordem por ela imposta.

Nessa perspectiva, é importante salientar que essa situação de "armário", vivenciada por Luciano, não aconteceu por causa de sua vontade de gritar ao mundo sua subjetividade. Lembremos que uma foto sua saiu em uma revista sem que o mesmo soubesse, sem que ele tivesse escolhido que suas relações entre iguais fossem reveladas. Assim, entendemos que o "armário" é uma metáfora criada e imposta pelos grupos majoritários a fim de classificar, apontar e julgar as minorias.

Voltemos ao texto damatiano. O clímax do conto se dá quando Otávio, percebendo e vendo seu filho no ápice do desespero, decide partilhar com ele o seu segredo mais íntimo. A fim de consolá-lo, inicia a confissão:

- O que o seu pai quer, e isso é o que todo pai cuidadoso deseja para um filho - continuou -, é vê-lo no caminho certo, no caminho que a sociedade traçou para todos nós, você compreende?' 
- Sabe, Luciano, quando eu era de sua idade também tive um amigo...'

$[\ldots]$

- Eu e o João Henrique nos tornamos inseparáveis, logo que nos conhecemos no colégio. Namorávamos duas pequenas - adiantou - que moravam na mesma rua, no Jardim Botânico. Pois bem, éramos tão amigos e gostávamos tanto um do outro que nos beijávamos na boca' (DAMATA, 1975, p. 169-170 - grifos do autor).

Tal como deveríamos presumir, a reação de Luciano foi de não acreditar, tendo em vista que a figura que ele tinha em sua frente era do homem ético, moral e que honra a família e o lar, que acabara de julgar seu filho por se relacionar com outro rapaz, sendo no mínimo incoerente. Para além da confissão do pai de Luciano, o que percebemos é o desejo do pai de respeitar os caminhos socialmente predefinidos e não deixar fluir o desejo do indivíduo. É interessante observar que Otávio, o pai de Luciano, também fora levado para o caminho do "bem", socialmente falando, através da exigência de seu pai, o avô de Luciano, que o obrigou, através de uma conversa na mesma biblioteca em que a cena se passa agora, a acabar com aquela relação de Otávio e João Henrique. A reação dele foi a seguinte:

[...] fiquei chocado e ao mesmo tempo revoltado, e me encontrava com ele [João Henrique] às escondidas, no Jardim botânico. Na ocasião - adiantou - 
o velho me fez ver que aquela amizade era perigosa, não podia nunca dar certo. E o curioso é que me comportei exatamente como você, agora. E de que maneira você poderia se comportar nessa sua idade e numa situação mais ou menos parecida? (DAMATA, 1975, p. 171).

Notadamente, a "saída do armário" vivenciada por Luciano foi impactante, pois não ocorreu por sua necessidade de assumir um posicionamento gay. Além disso, naquele momento, ouviu de seu pai a declaração sobre a experiência frustrada que tivera em sua adolescência, tentando mostrar ao filho que a situação poderia ser revertida. Entendemos que o objetivo da hipócrita confissão foi apenas para que Luciano percebesse, em Otávio, um vencedor, por ter superado aquele caminho errado ao seguir as regras que o seu pai, avô de Luciano, impusera: sublimar o desejo que tinha por seu amigo João Henrique e se adequar à ordem social, fazendo com que a vida seguisse no padrão esperado pela sua família:

- Pois é, reatei o namoro com a sua mãe, fui trabalhar no escritório de advocacia do seu tio Olavo e à noite estudava, fui um dos primeiros alunos da minha turma, na Faculdade. Casei uma semana após a minha formatura e até hoje não me arrependi. Sou um homem feliz, realizado - disse em conclusão, com a voz grave, nostálgica, já de pé, pronto para sair (DAMATA, 1975, p. 171). 
Diante do sermão apresentado por Otávio, a atitude de Luciano é seguir o mesmo caminho que seu pai: cumprir o papel que se espera de uma pessoa do sexo masculino. Badinter (1993), em $X Y$ : sobre a identidade masculina, apresenta-nos esclarecimentos acerca desse sujeito masculino, de como nasce e o que é (ou vem a ser) esse homem, construído com grande esforço e trabalho, pois a virilidade necessária para esse tal sujeito não é facilmente adquirida. O que há, de fato, é uma constante luta para que ele seja tudo o que não o faz ser mulher: forte, bruto, insensivel, másculo, provedor.

A fim de cumprir o que o pai lhe sugeriu para que voltasse a ser um homem, Luciano decide reatar o namoro com uma menina e fazer plano para serem "felizes para sempre", porém, no caminho, a sua vida é interrompida em um acidente, que é descrito no conto da seguinte forma:

Dobrando a esquina numa curva fechada, perigosa, entrou na São Clemente, sentindo na velocidade que imprimia à maquina um prazer infinito, um estranho orgasmo fruto de suor e vento, que lhe molhou as calças; e a uma quadra de atingir o Santo Inácio, deu-se o inesperado. Procurou desviar-se de um caminhão feireiro que de repente surgiu por trás do bonde, mas bateu na parte lateral da carroceria de um carro-tanque da Esso que minutos antes deixara para trás; cuspido na calçada, esfacelou o crânio num poste e morreu instantaneamente, sem dar 
tempo ao padre Bonifácio de colocar a vela na sua mão e recomendar-lhe a alma (DAMATA, 1975, p. 173).

A morte de Luciano não representa tão somente perder a vida, e sim, uma morte alegórica, que nos faz pensar nas pessoas que morrem ou estão morrendo ao tentar camuflar seus desejos e manter-se no "armário", assumindo um papel que não é o seu, frustrando-se a cada dia. Além disso, podemos perceber que essa morte, enquanto materialidade fisica, realmente, pode configurar-se como a chamada "moral da história" que, frequentemente, está presente no gênero textual que intitula o conto analisado, ou seja, o resultado para quem infringe as regras postas, social e culturalmente, é a morte.

O desfecho do conto nos faz pensar sobre esse assumir-se. Ora, o pai só confessou sua experiência ao filho com o intuito de mostrar-lhe que, apesar de ter "agido mal", conseguiu voltar aos caminhos corretos, seguindo os conselhos do avô de Luciano, apresentando essa experiência como uma forma de seu filho escapar do mal, que o assolava. Percebemos, com isso, que o "armário" é um lugar de tensão, e que sair dele gera confronto, mas permanecer nele também o gera, e ser colocado fora dele não é o que traz tranquilidade, uma vez que a própria noção de "armário" é proveniente de uma ação social verticalizada.

Um questionamento importante que perpassa todo o assunto do "armário" é saber: de 
fato, ele existe para os sujeitos homoeroticamente inclinados ou é uma criação de um grupo para enclausurar tudo aquilo que foge às normas sociais? É notório que, frequentemente assumir e não assumir está ligado a uma regulação do grupo dominante, e não é fruto da subjetividade de cada sujeito. Essa regulação é posta de tal forma que ficar no "armário" pode ser visto como permanecer no lugar do medo, da covardia e da insegurança, mas também pode ser visto como estar no conforto, uma estratégia de se manter em um lugar no qual os influxos externos não atingem o sujeito.

Vale a pena ressaltar que o "armário" não é apenas um dispositivo gay, pois cada multidão de minoria tem seu "armário", tem aquilo que prefere ou precisa guardar para evitar a exposição diante de uma sociedade que julga o comportamento dos indivíduos. Ocultar evita uma série de reações preconceituosas. Entretanto, até que ponto é importante essa rejeição de si, e de sua identidade? Até que ponto é válido o esconder-se de si? Ressaltemos que essa ambivalência entre a "rejeição de si" e o “assumir-se" está diretamente ligada aos sujeitos que desejam seguir a vida a partir de uma postura gay, que desejam vivenciar plenamente sua subjetividade, definida como tal, dentre os que têm consciência dessa masculinidade.

Voltando aos contos de Damata, ainda relacionando as questões de público e privado, um conto em especial nos coloca diretamente diante da relação que não está apenas no âmbito dos iguais. Em $O$ inimigo comum, 
conhecemos um casal, um velho da Marinha e seu jovem amante Otávio, que se atrasa para seu encontro com o velho devido a uma conversa que tivera com sua namorada. O velho,

[...] fazia parte de um grupo de senhores que costumavam ficar sentados na praça até altas horas da noite conversando; sujeitos que já tiveram o seu tempo [de michê] e hoje vivem de saudade e da recordação (e nada para eles presta) (DAMATA, 1975, p. 51).

Enquanto esperava seu amante, o ambiente é descrito, a Cinelândia, com seus encantos e os mais diversos personagens e performances masculinas.

Uma descrição em especial nos chama atenção, enquanto somos convidados a esperar junto com o velho a chegada de seu amante:

Num banco mais afastado, quase no fim da praça, dois senhores conversavam já há bastante tempo. Por fim se levantaram e saíram despreocupadamente. Eram caso, viviam juntos há trinta anos ou mais, verdadeiro recorde de sobrevivência debaixo do mesmo teto numa época em que mesmo os casamentos entre homem e mulher já não duravam muito, desfaziam-se por qualquer tolice. Onde quer que um estivesse o outro também estava (ou não tardava a aparecer), sendo que o mais novo costumava andar por toda a parte com o braço por cima do outro, numa prova de desinibição e 
carinho, e consta que entre eles nunca houve infidelidade ou brigas grossas (DAMATA, 1975, p. 52).

Damata apresenta esses companheiros como modelo para outros casais, sejam eles hetero, homo ou bissexuais. Estes personagens são significativos para o livro, na nossa leitura, por se tratar de um par em que o "armário" está aberto independente do que a sociedade possa dizer deles, sem nada a esconder, assumindo todo o risco de apresentar ao mundo a subjetividade gay e enfrentando o perigo que o preconceito dos outros pode causar.

Voltemos ao velho marinheiro e seu amante Otávio, que, finalmente, ao chegar ao encontro, põe em pauta aquele que se tornou o inimigo comum das relações masculinas homoeróticas, na visão do velho marinheiro: a mulher. O velho, que, por algumas vezes, precisou manter relações com mulheres por conta do cargo que ocupara, lembra que "só ia mesmo com uma puta lá da zona quando não havia mais jeito, ia a bem dizer por obrigação, pra despistar" (DAMATA, 1975, p. 57). Evidente que esse despistar se refere ao fato de os outros colegas não perceberem a sua repugnância para com as mulheres.

Apesar de toda aversão que é descrita em várias páginas, ao perceber que Otávio se encontrara apaixonado por uma mulher, caindo em choro pelo sentimento que o tomava, o velho, movido por essa comoção e, notadamente, para consolar seu "rapaz", refaz seu discurso e afirma: 
- Sou contra mulher, é sem vergonha, que não faz por onde merecer, meu camarada. Depois, cada qual tem seu gosto, respeito o gosto alheio. Quer saber mais? Já estou velho, cansado. Qualquer dia desses bato a bota, não, vou pro outro mundo, como se diz. E como é que você vai ficar, vamos, me responda? Sem ter quem tome conta de você, quem faça as coisas pra você (DAMATA, 1975, p. 62).

Observemos que, posto entre o rapaz objeto de seu desejo e o seu "inimigo", o velho recua e mostra-se mais aberto a essa relação de Otávio com a mulher, vislumbrando, sobretudo, que seu rapaz tenha alguém para cuidar dele, independente de quem seja. Otávio se coloca diante de dois desejos diferentes tanto dele para com seu velho, quanto para com sua namorada. No entanto, não podemos considerar que vivenciar esses desejos o coloque fora do "armário", tendo em vista que, em nenhum momento, Otávio assume uma subjetividade gay, apenas dá vazão aos desejos.

$\mathrm{O}$ fato de os personagens direcionarem o desejo para homens e mulheres também está presente em "Muro de silêncio", pois o fuzileiro, amante do velho, engravidara uma mulher, tornara-se pai, mas não deixara de manter o relacionamento com o seu amante, que, por muitas vezes, foi quem financiou suas despesas. Ou seja, a relação de afeto e desejo era existente e duradoura, mas o fuzileiro não precisava assumir-se gay, se não o era. Nomear, enquadrar e 
engessar as relações, ao invés de simplesmente deixar que as sensações tomem conta, essa é a realidade que temos no que diz respeito aos afetos e ao que conseguimos ver deles. Ver e julgar, verbos que estão sempre acompanhados dos "armários" que nos cercam.

Em O crucificado, o "armário" é apresentado, via confissão dos pecados dos sujeitos homoeroticamente inclinados, para o padre da igreja católica. Além de toda a relação de amizade entre José Tércio e Dom Vicente, o enredo desse conto traz a confidência do amor entre iguais e as suas consequências. No momento em que José Tércio confessa ao padre que mantinha relações com seu igual, ele o fazia pela necessidade de arrancar da alma o que lhe afligia, a sensação que lhe tomara era de quem acaba de fazer papel de ridículo:

\footnotetext{
[...] fora ter com Dom Vicente logo cedo, antes de entrar no escritório, a fim de livrar-se de um problema que o atormentava. E não apenas para se confessar ou se converter, como era o desejo de muitos. E também do próprio beneditino, talvez (DAMATA, 1975, p. 177).
}

Em contrapartida, o padre surpreende ao afirmar-lhe que

- Essas coisas não podem ficar assim tão ocultas, em segredo absoluto. É muito perigoso. A pessoa precisa desabafar com alguém, livrar-se do 
peso. Há sempre um amigo que ajuda, no qual a gente confia um pouco mais (DAMATA, 1975, p. 184).

A posição do padre é acolhedora e confortante para com seu confidente e, consequentemente, para com todos aqueles que o procuravam para desabafar, mas não saíam de lá totalmente ilesos, tendo em vista que o padre apontava os que desejavam seu igual como responsáveis pelo preconceito sofrido: "mas se procediam assim, é porque sabiam que iam viver a vida toda maltratados, escarnecidos, na rua e dentro de casa" (DAMATA, 1975, p. 206). O preconceito não está na minoria e sim no outro, no grupo socialmente favorecido por ser o mantenedor da ordem, por não gostar ou não aceitar que cada um viva da forma como queira para experienciar a felicidade.

O desfecho a que chega o conto, assim como em Fábula, é com uma punição para a exposição, uma vez que José Tércio é assassinado, ou crucificado por suas escolhas, se é que ele escolheu em algum momento ser vítima de violência, preconceito, intolerância. A liberdade é o principal objetivo de viver, ser livre é o desejo de muitos indivíduos com os quais convivemos: não precisar mentir, não viver uma farsa, não esconder os seus desejos mais recônditos, o que lhe inspira a vida. Por vezes, ser livre custa um preço muito alto.

O que está posto nos textos de Damata nos faz pensar que transferir a sexualidade do âmbito do privado para o do público só se faz 
necessário por causa da representação das minorias, por causa das politicas públicas. Nesse sentido, o sair do "armário" pode significar, de fato, não sair para lugar nenhum, sair do "armário" para estar preso numa redoma de vidro, em que todos podem ver a subjetividade do individuo exposta, mas este nem sempre poderá se juntar aos demais.

\section{Considerações finais}

Diante da análise empreendida, pudemos confirmar a ideia de que não se pode falar em uma única masculinidade, nos levando a sair desse universo imposto socialmente em que o homem é somente aquele ser viril. O que temos nos contos é a presença de homens que assumem performances que vão além deste eixo: alguns são sensiveis, outros são ciumentos, há ainda os que temem o que os outros individuos possam pensar deles, os que vivem sob o domínio da família ou de seus amores.

Os solteirões nos proporciona conhecer, via ficção, o que se passa na sociedade carioca da década de 1970 e que se percebe ainda nos dias atuais: as possibilidades de ser além do que está imposto socialmente, tendo em vista que, por mais que percebamos existir uma variante que se quer dominante, o que os estudos apontam são as masculinidades que acolhem cada individualidade dos sujeitos masculinos, nas relações entre iguais ou não.

No que diz respeito ao "armário", o que 
apreendemos é que estar/permanecer/sair deste lugar, para os sujeitos do universo construído por Damata, está relacionado à conveniência, não no sentido de covardia, mas no sentido de preservar a subjetividade do sujeito. O que se percebe, ao final da leitura, é que o desejo de sair ou não do "armário" está mais para o interlocutor do que para a satisfação pessoal.

De um modo geral, os sujeitos confessam suas experiências àqueles que fazem parte de sua zona de conforto, outras vezes coagidos a sair do "armário", e raras são as vezes em que, de fato, adotam uma postura subjetiva diante da sociedade. Assim, pudemos confirmar que as relações estabelecidas entre os sujeitos gays e o "armário" são resultantes da imposição dos grupos detentores do poder e não provenientes do desejo de cada um de se assumir enquanto sujeito sexual e de gênero. 


\section{Referências}

BADINTER, Elisabeth. XY: sobre a identidade masculina. Tradução de Maria helena Franco Martins. Rio de Janeiro: Nova Fronteira, 1993.

DAMATA, Gasparino. Os solteirões. Rio de Janeiro: Pallas, 1975.

HOWES, Robert. Solidão e relações de poder na obra de Gasparino Damata. In: COSTA, Horário et al. (Org.). Retratos do Brasil homossexual: fronteiras, subjetividades e desejos. São Paulo: Editora da USP; Imprensa Oficial, 2010.

KATZ, Jonathan Ned. A invenção da heterossexualidade. Tradução de Clara Fernandes. Rio de Janeiro: Ediouro, 1996.

NOLASCO, Sócrates. O mito da masculinidade. Rio de Janeiro: Rocco, 1993.

. Um homem de verdade. In: CALDAS, Dário (Org.). Homens. São Paulo: SENAC, 1997.

PERLONGHER, Néstor Osvaldo. O negócio do michê: prostituição viril em São Paulo. São Paulo: Brasiliense, 1987.

PRECIADO, Beatriz. Multidões queer: notas para uma política dos anormais. Estudos Feministas, Florianópolis, v. 19, n.1, p. 11-20, jan.-abr. 2011. 
SILVEIRA, Micaela Sá da. As masculinidades no conto Paraíba, de Gasparino Damata. In: ANAIS DO IV CONGRESSO INTERNACIONAL DA ABRALIC, 13, 2013, Campina Grande. Campina Grande: UFPB, 2013 v. 1.

SEDGWICK, Eve Kosofsky. A epistemologia do armário. Cadernos Pagu, Campinas, n. 28, p. 19-54, jan.-jun. 2007. 


\title{
IMAGENS DO HOMOEROTISMO NA FICÇÃO BAIANA
}

\author{
Paulo César Souza García ${ }^{1}$
}

A representação do homoerotismo na ficção contemporânea tem dado amostras de enunciados sobre os desejos sexuais excludentes, sobre os corpos que pesam (BUTLER, 2000) e sobre as bases que focalizam o subalterno. Um estudo de Flávio Camargo, a respeito do homoerotismo na obra de Caio Fernando Abreu, afirma que a produção literária do autor é referência ao preconceito, à discriminação e à violência homofóbica:

[...] simplesmente porque ousaram expressar e expor ao público seus desejos, sua identidade, sua sexualidade. De tal forma que as experiências homoafetivas e ou homoeróticas, assim como os ritos de iniciação sexual e de passagem são balizadas, muitas vezes, pela presença constante da violência (CAMARGO, 2011, p. 241).

1 Doutor em Teoria Literária (UFSC). Professor da Graduação em Letras e da Pós-Graduação em Crítica Cultural da Universidade do Estado da Bahia - DEDC II (UNEB).

E-mail: 〈p.garcia@terra.com.br〉. 
O exemplo da análise oferecida por Camargo em relação a Caio $\mathrm{F}$. é sintomático de leituras que manifestam os questionamentos sobre as identidades, uma marca que a literatura moderna e da contemporaneidade tem proporcionado aos leitores mais ávidos pelas pesquisas sobre gênero e diversidade sexual. Se em Caio F., a experiência homoerótica ganha corpus de enunciação, ainda mais presente com o sentido da ausência e carência de afetividade do sujeito, como pensa Camargo (2011), em muitas outras obras da literatura brasileira esta inquietação em falar de si não somente delineia e ilustra o traço da identidade homossexual, como se reporta ao poder falar sobre.

As narrativas de Caio F. anunciam os imperativos e os flertes homoeróticos, que são perceptiveis a olho nu e na artimanha da sociabilidade entre homens. Algumas narrativas, a exemplo do conto "Aqueles dois", são porta-vozes de relatos que articulam o desejo gay através do toque do corpo, do olhar, das sensações, de sentir os gostos e prazeres anunciados. No relato "Aqueles dois", o envolvimento homoerótico sai do anonimato, dando preferência ao amor e não apenas ao sexo, mesmo que, como pondera Flávio Camargo, Caio F. assegure "a onipotência da solidão, por um sentimento de falta, de carência afetivosexual, por um vazio existencial e pela angústia" (CAMARGO, 2011, p. 242).

A partir da imagem dos desencontros afetivos situados na metrópole moderna, nota-se 
mais ainda o emaranhado de existências excêntricas demarcadas nas zonas de desvios, sobressaindo a carência, a solidão, o medo de amar. Como Caio F., João Gilberto Noll apreende os desfalques da identidade masculina na onda da vida líquida (BAUMAN, 2004), nos desvãos de um tempo atravessado por evasões, por fugas, pelos entrecruzamentos de relações individuais muitas vezes nada assépticas. Como crítico de uma realidade retratada, Noll se vê imerso numa linguagem que não deve ser seguida pela estrutura binária, já que as histórias apresentam eixos de sentidos nada lineares e são mais descentralizadas da unidade do signo. Os enredos se mostram no plano do rotativo, com descrições avessas a lugares fixos e é nesses entrecortes discursivos que o estilo do narrar do autor se apresenta sobressaltado, destacando a inserção de personagens fora-de-lugar.

Talvez, frente a isso, a escrita de Noll seja girada pela consequência de perceber o real nutrido por dados reguladores que contaminam a esfera da subjetividade. Assim, suscitam as relações afetivas entre homens, que temem locar a chama unificadora do amor, porque o ato de amar é visto pelos personagens masculinos como um ato de integração, de ligação a um ser estranho. Sendo assim, sobressaem o vazio da existência e a incapacidade de o homem lidar com o sentimento de perda e de desapego. Algumas dessas motivações existenciais giram em torno da aproximação amorosa e sexual que configura o amor 
líquido, podendo estar atrelado, aí também, o dispositivo imposto a cada pessoa que se submete ao poder totalitário da vida moderna, ao consumo e à necessidade de gozar a todo custo (BAUMAN, 2004).

O manifesto de Bauman pode dar mostra à interpelação do sentido imposto, à revisão do centro dos conceitos assépticos, pondo em ação os reflexos sobre quem fala e como fala. Se as faces dos sujeitos da literatura são desenhadas não para reproduzir o real, mas para envergar a linguagem que reflita as assimetrias, os desarranjos, a desautomatização ordinária da realidade, assim visto, o ato de diferir dos narradores ficcionais é proposital, uma vez que a escrita literária flerta com o lado de fora, com os instantes em que a linguagem difere de si mesma, ou seja, é a própria diferença da língua se desdobrando para recondicionar o sentido da realidade. Dessa forma, as singularidades das escritas do literário acusam a alternativa de novas outras formas de expor a si, daqueles que estão fora-de-lugar ou no entre-lugar (BHABHA, 2001).

Ao apresentar a parte introdutória e propositiva sobre a literatura de Caio F. e de Noll sob o aspecto do homoerotismo, pretendo dar enfoque à literatura baiana da contemporaneidade. A obra da escritora baiana Állex Leilla ${ }^{2}$ revela imagens propositadamente deslocadas com o representável, que dá vistas

2 Urbanos (1996), o sol que a chuva apagou (2009), Primavera nos ossos (2010) são obras publicadas pela autora na geração atual da literatura baiana. 
a instaurar uma força-motriz que enaltece o poder falar de si a serviço e à ordem do consumo do corpo, para reaver a capacidade de desafiar o medo social diante das entregas do desejo homoerótico. Situo o romance Henrique (2001), cujos sentimentos das personagens são enaltecidos, à mercê do fracasso e da culpa, da cumplicidade e da perseguição, dados os tabus da vida ordinária ligados à homossexualidade pecaminosa e aos estorvos familiares. O amor homoerótico é focalizado sob um discurso anti-higiênico para os padrões morais, porque nos diz muito da relação de fórum edipiano, quando expressa o contato homoafetivo entre pai e filho e entre irmãos. A literatura de Állex Leilla descreve a discrepância do patriarcalismo e desnuda o sistema familiar regrado e conservador.

A história de Henrique parte da ação do protagonista, que dá nome ao romance e se desdobra em algumas micro-histórias, como o amor que Henrique nutre por Victor, melhor amigo de infância. Um sentimento amoroso que atravessa a adolescência e vai até a maturidade, mas passado pelos percalços da dúvida, do medo, dos questionamentos a respeito de sua orientação sexual, consequência dos rígidos padrões sociais e familiares. O narrador - protagonista interage com as diferentes experiências que são mediadas pela focalização de outros autores da literatura situados no texto, remetendo ao corpus discursivo, diálogos que se contrapõem ao heterossexismo e às declarações avessas à heteronormatividade. 
No enredo do romance, são pautados a repressão, os paradigmas heterossexistas, o arbitrio, o autoritarismo de convivio familiar, a quebra de conceitos heteronormativos, a imagem do pai do protagonista que se desencaixa dos elos do sistema patriarcalista e aposta na amizade intensa com o filho, esta expressa pela convivência mais livre entre os dois. No entanto, o amor de Henrique pelo pai vai além do espiritual, concentrando-se na esfera sexual. O corpo fala mais em razão do desejo sexual, ressurgindo a tensão de base edipiana. Mais do que uma relação transgressiva, Henrique se desvela, mostra a si mesmo no plano do desejo mal-dito, no poder de enunciar a si no espaço da exceção, ou melhor, buscar a identidade para além da limpeza dos relacionamentos sagrados e normativos, ao consagrar a presença do pai:

A palavra homem para mim estava diretamente relacionada à imagem do meu pai. Mas ele sempre foi ligado a todas as formas de vida que há na Terra, sem predileção especial por nenhuma e convivendo naturalmente com todas, como eu procuro até hoje viver, como sempre procurei e nunca pude. Há formas de vida que desentendo completamente, há outras que odeio... [...] Meu pai, uma tragada lenta e profunda, os glandíolos que ele me trouxe ontem ainda vivos, as pausas que seguem sozinhas, independentes de um querer definido. Meu amor. Depois do amor, pode-se furar mesmo os olhos. É coisa mais certa de se fazer (LEILLA, 2001, p. 141-144). 
Luís também confessa ao filho a relação incestuosa com o irmão. Para ele, um relato libertador, quando condiciona uma relação aberta e amorosa para o filho. A quebra dos conceitos arraigados heteronormativos sobressai com a consideração de Luís, que não enxerga nenhum problema em amar e transar com o irmão. Os irmãos Leão e Luís sentem desejo sexual um pelo outro desde criança, desejo despertado pela atração física, criado sem traumas. Parece que a trama espreita o imaginário social com o ato do confessionário, sendo este adentrado na enunciação de descobertas, de desmascaramentos, de rever os fantasmas que eles não se veem e de se perceberem como os excluídos. A escrita transita livremente por lugares nada convencionais e nada confortantes para o seio familiar de base fundamentalista e patriarcal. Até a descoberta do pai de Luís e Leão, que exalta a condição sagrada e pecaminosa do sexo homossexual entre os filhos. Um retrato discursivo que volta ao plano do mesmo, que retorna para a imagem e para os dispositivos da repressão:

Meu pai me contou uma vez a sua história, ou parte dela, talvez. Quando completara cinco anos e o tio Leão tinha oito, a mãe os pegara nus. Cinturas coladas, fundindo-se numa só. Foi um escândalo. Ah! Ele adorava o Leão, cresceram assim, unidos. Dormiam abraçados sempre que podiam. Acariciando-se, mordendo-se um ao outro. Faziam tudo juntos. E apanhavam juntos também. Os pais 
estranhavam tanta proximidade. - E trepávamos sempre. Muito além do que podiamos. Não tínhamos outros amores. Éramos um pro outro. Até os meus 17 anos, ninguém sabia que a gente se amava. A-t-é-q-u-e-u-m-di-a... - Enfim, descoberto tudo, ficou claro que não era só uma brincadeira de criança, pois, mesmo depois daquele flagra (pelo qual fomos seriamente punidos, é bom que se lembre), nós nunca deixamos de nos amar. Então vieram mais porradas, todas as repressões, todas as pieguices, todos os chavões dramáticos (LEILLA, 2001, p. 63-64).

Se Luís abala o pensamento dicotômico normal versus anormal ao relatar para o filho o amor homossexual com o irmão e depois com o próprio filho, ele não somente mostra ser livre da imposição aos sentimentos de vínculos familiares, como enuncia criticamente os valores relacionais heterossexistas e heteronormativos da cultura ocidental postos em xeque, como também critica a estrutura dos modelos da cultura judaico-cristã, fazendo ruir o pensamento fundado na versão homem versus mulher. A válvula de escape se dirige para a negação da fórmula do amor heterocentrado limpo, desautorizando os elos comunais religiosos. Se existe uma "violência" ao corpo anunciada entre pai e filho e entre irmãos, ela simboliza a desvinculação dos rótulos e de nomeações instituídas, pois aí a reflexividade do corpo não abdica de se vincular aos novos perfis dos relacionamentos, tendo em vista os 
atos homoeróticos e as identidades construídas por novos rumos e rotas.

Pode o sujeito gay ocupar este lugar de fala? As histórias que nos são narradas em Henrique convidam a reposicionar o amor gay na errância sexual, abordado para reproduzir o controle dos corpos, a destituí-lo, e para repensar as perseguições dos que ousam amar o outro do mesmo sexo. Os relacionamentos homoeróticos, traçados no livro Henrique, causam estranhamentos por ter em mente "a perpetuação do interdito sobre a sexualidade, e por silenciar ou punir tudo e todos os que não são contemplados pela moralidade burguesa ou que nela não se enquadram", como bem define Emerson Inácio (2010, p. 113). Aqui, o relato do amor entre pai e filho, e entre irmãos, pode ser representável no espaço ficcional, visando ao lugar da subalternidade para exercitar interpretá-lo na repetição dos contextos históricos e culturais, como para visualizá-lo e analisá-lo diante do legítimo poder social versus as identidades e as categorias de gênero e de orientação sexual.

A experiência do infame amor homoerótico no romance pode ser um percurso de leitura que tenha em mira a forma de interpretar $\mathrm{o}$ devir-sujeito, de situá-lo na movência, na contramão e na contradição de sentidos arraigados pelo centro hegemônico. Se importa para a literatura de temática homoerótica a desterritorialização de lugares fixos e reterritorializar percursos mais fluentes para saber de si e do outro, as escritas se deparam com a minoria que não se lê, não se vê, não se escreve. 
Destaco o livro de contos do escritor brasiliense Lima Trindade ${ }^{3}$, Corações blues e serpentinas, cujas histórias enredam a imagem de homens refletida nos perfis de personagens brancos, de classe média, situados em passados sombrios, que são tenebrosos ao vivenciar o amor gay. Aí, o imaginário se presentifica numa carga de preconceitos, ao lidar com o desejo homoerótico vasculhado na espreita. $\mathrm{O}$ olhar do personagem é sempre penetrante, enviesado. A paquera ao parceiro desconhecido reproduz as condições históricas de marginalização e clandestinidade dos contatos entre homens, como se o fato de as expectativas de entrega ao corpo do outro girassem em torno do apaziguamento e do sofrimento do amor.

Assim, o universo da escrita de Lima Trindade investe em personagens que buscam o lado masculino homossociável e, ao mesmo tempo, são acobertados pelos códigos morais, celebrados por um tom de lirismo, deixando evocar o enaltecimento do belo e a exaltação de si no confessionário da enunciação. No conto "A primeira vez", a personagem reverbera o homem, exaltando a beleza do masculino e o problema de afirmar a orientação e o desejo sexuais:

[...] lembro que tinha um espelho na sala e eu não olhava diretamente para ele, mas para o espelho, porque assim

30 escritor nasceu em Brasília, mas adota a Bahia para viver. Publicou Supermercado da solidão (2005), Todo o sol mais o espírito santo (2005). 
ninguém descobriria o que comigo se passava: que eu estava apaixonado e com medo que alguém pudesse desconfiar de meu amor que naquela hora não era todo consciente, era meio misturado à bebedeira. Sim, era a bebedeira que fazia isso com a gente, confundia o gosto e a noção de beleza, porque um homem não pode achar bonito outro homem, ainda mais se a beleza tiver uma aura de sensualidade (LIMA TRINDADE, 2007, p. 89).

A narrativa mostra a identificação de práticas repressoras, quando a beleza do homem é alvejada e revisitada por meio da metáfora do espelho. Do lado de fora da realidade, reflete o ser discriminado por revelar o desejo abreviado e, por sua vez, a referência ao gay é sempre visada pela condição de subalternidade. Dito isto, o olhar reescreve as polaridades que envolvem a identidade sexual, levadas pela discrição do personagem e pela inserção do olhar de fora que estigmatiza, projeta-o como desviado, indecente e pervertido. A narrativa preserva nuanças que colaboram para pensar o personagem ocupando o espaço da exclusão diante do gesto de domesticação de si, também ligado às estruturas débeis do sistema sociocultural, movidas pelas significações ortodoxas e hierarquias estabelecidas.

Em "Amor inconsútil”, outro conto do autor da mesma coletânea de Corações blues $e$ serpentinas, a narrativa promete dissolver o instituído e os conceitos transversais do amor, compreendendo a coexistência do sentimento 
amoroso entre dois homens. A narrativa apresenta o dilema entre André e Antônio mostrado no ápice das cobranças. "- Você me ama. - O que é amar? - É me possuir como se eu fosse um cãozinho, protegendo e alimentando... - Então, não te amo" (LIMA TRINDADE, 2007, p. 45).

Para Enrique Rojas, "é preciso construir uma nova pedagogia do amor, partindo de nós próprios e não do prazer sexual colocado à frente do amor" (ROJAS, 1996, p. 50). O amor de Antônio beira à insegurança, o temor da perda, sinalizando, em primeiro plano, a posse do corpo de André. Na tríade amorosa, surge Lúcio na vida de André, que o faz rever a postura e o significado da convivência com outro homem, numa flagrante concepção de que o relacionamento amoroso homossexual é prescrito e semelhante aos padrões heterossexistas, que aprisiona, sufoca, corroendo a relação, ou é instrumento do corpo a serviço de saciar a sede sexual:

Lúcio nada cobrava, não pedia amor nem gestos de carinho. Quando falava, eram sempre a respeito de coisas não refletidas, condicionadas. Você viu o último capitulo da novela das oito? Conhece a piada do...? estou a fim de comprar um carro novo (LIMA TRINDADE, 2007, p. 45, grifos do autor).

A experiência de quem fala no contexto civilizado urbano, em que se aborda o vínculo com o sexual homoafetivo, demarca o limite do 
eu e do outro, ainda mais quando surge "no modo como as transformações do capitalismo são correlatas de mudanças nos modos de relacionamento afetivo instituído no corpo social" (CUNHA, 2009, p. 103). Para Giddens (1993), a experiência segregada, de acordo com o pensamento positivista, refere-se ao processo de ocultação que separa a rotina da vida ordinária dos envolvimentos vários do social. Portanto o envolvimento homoerótico de André por Antônio pode traduzir o medo de se tornar dependente de outra pessoa e, como argumenta Sennett (2003, p. 167), "é uma falta de confiança nela; em vez disso, prevalecem nossas defesas". A defesa de não se envolver amorosamente e o máximo é se engajar no corpo, na zona fronteiriça do prazer, foco da elocução da narrativa:

André não queria mais ilusões. Queria a deriva. E mais, existe o medo de envelhecer, de perder a vitalidade do corpo, de ser negado como idoso e gay, de modo a ser indagado por Antônio: - Não sou mais um garoto para você? - Por que pergunta? Eu é que devo ser velho demais para você. - Mas não era quando eu tinha dezessete e você cinquenta, André. Ou, pelo menos, você não parecia pensar assim - disse num tom triste, porém calmo. - Eu te amo mais que tudo André! O meu amor é um amor sem fronteiras e sem remendos. O que é sexo perto disso? Depois, ficaram mudos por muito tempo. Até que André se vestiu e, sem se despedir, foi ao encontro de Lúcio. Não voltou para pegar os livros (LIMA TRINDADE, 2007, p. 46-47). 
Para Antônio, resta comungar a ideia da pedagogia do amor, como afirma Rojas. Para André, o amor deve ser vivenciado para além do domesticado, efetivamente fugaz ou, melhor dizendo, atravessado pela livre expressão de si. André contextualiza os gestos de deriva sexual, mais sexo, menos amor, reforçando o tecido dos textos que representam os solitários determinados a encarar a individualidade com suas mutações rápidas e ininterruptas típicas da imagem fugaz da realidade social (SIMMEL, 1967), pois, aí, mostra-se o semblante do anônimo atraído mais na onda da "vida liquida", problematizada por Bauman, ou seja, sujeitos fadados a condições de incertezas constantes. Assim, também, as relações amorosas homoeróticas são pautadas na versão perniciosa de competição, de interações, de exclusões, vidas mais liquidas, menos assépticas, se comparadas com os padrões heterossexistas.

Em "Eu James Gandolfini (ou Jukebox)", conto publicado no livro Geração zero zero: fricções em rede, organizado por Nelson de Oliveira, o protagonista da narrativa se vê na pele do personagem do cinema, interpretado por James Gandolfini, um gordo que assume sua identidade sexual. Como um flâneur, o protagonista transita no basfond do centro de São Paulo, no bar "Caneca de Prata", local em que os ursos, assim denominados os gays peludos e gordos, se encontram e paqueram, jogando com as piscadelas de olhares que atraem aqueles que se distanciam de corpos moldados e sarados. 
Em estudo sobre a manifestação do corpo, Wilton García (2001, p. 89) afirma que

[...] a erótica aparece na expectativa do trânsito. Como agente intermediário do corpo, o Eros trata de adequar as condições possiveis para manter a energia pulsante da vida. [Quer dizer que,] dentro dessa circulação apresentada, o objetivo principal é 'estar em atividade', não importa a chegada ou partida, mas sim o deslocamento num movimento entremeio. Portanto, a erótica está no intervalo (GARCÍA, 2001, p. 89).

Dentro desse contexto, o personagem parece seguir o exemplo salvaguardado na aversão aos corpos sarados e projetados como referencial para atrair o olhar do outro, com todos os músculos tonificados, com todos os corpos másculos, sarados e "higienizados":

[...], penso, agora, aqui, sentado junto ao balcão - ainda mais que não chovia havia um bom tempo e eu não costumava avançar pelas ruas com uma garrafa de conhaque debaixo do braço, oprimido pelo intuito imperioso de encontrar alguém que me amasse como eu era - grande, gordo e calvo; olhos bovinos, mas dentes brancos e perfeitos -, porque eu me cuidava de verdade, gostava de mim, gostava tanto que me mimava às vezes e ouvia Charles Mingus com a paixão de quem faz tudo isso sem comer morangos mofados (LIMA TRINDADE, 2011, p. 400-401). 
Na contramão do corpo barbie, o protagonista apresenta a clave urso como parte de um terriório em que o desejo é confinado. Aposta na brutal evidência do excesso do corpo e, no reflexo do outro, não se deixa vencer pela autodeterminação homoerótica recortada no décor do físico.

Cães - melhor diria, ursos? - zelosos, protegendo a fachada do bar. Todos eles lembram um pai perdido, um pai que, por um desentendimento qualquer, juntou as tralhas e ganhou $\mathrm{o}$ mundo (LIMA TRINDADE, 2011, p. 401).

Assim, a metáfora do urso é pertinente para destacar outros códigos de vivência homoerótica, ganhando face e visibilidade.

Ao construir a imagem do urso, o narrador busca se autorrefletir com as caricaturas adotadas e o meio de atrelar, à estrutura social, a identidade gay pelo formato único do corpo. O protagonista não se autopune por ser gordo e peludo, mas internaliza seus signos na linha de discurso que os discriminalizam, desenhando uma nova relação identitária com a cultura gay. Narrador e personagem da história preenchem com a imagem de si as circunstâncias em que se deparam com a matéria de vida reinventada. O próprio personagem se constitui como sujeito de discurso, contracenando com os aspectos mais próximos de si, posto que escreve a partir do olhar que capta as imagens homoamorosas: 
O baixinho ao meu lado possui um olhar tristíssimo, apesar do sorriso meigo e dos gestos seguros ao levar a caneca de bebida à boca, molhando a barba de espuma. Ele não parece meu pai. Quero dizer, todos parecem pais quando são ternos e acolhedores. Que se fodam Freud e seus complexos. Somos eu e ele. Dois caras. Homens. Que se amam. E o baixinho é bem bonito. O incrivel neste bar é justamente isso, nele você pode ser e querer o diferente. Dar-se ao luxo até de ser malencólico numa noite seca de outono. E romântico (LIMA TRINDADE, 2011, p. 402-403).

Sob certa rubrica autobiográfica, a narrativa James Gandolfini, pretensão do autor implicito e personagem da história, trata de demarcar o momento em que a verdade das subjetividades ampara um elo discursivo: a forma de se subjetivar em experiências homoamorosas. "Fumo meu cigarro. Sou James Gandolfini e posso me transformar em Jack Radcliffe de um instante para o outro, se desejar. Eu James e Jack" (LIMA TRINDADE, 2011, p. 403). O desdobramento de si atenta para o modo como o personagem relata a experiência do movimento do seu corpo e, enquanto o faz, cria os signos que representam a si mesmo, uma imagem de si no tempo exato em que segue com o olhar o homem baixinho que deseja conhecer:

De qualquer modo, viro-me em direção ao homem árabe. Ele pode se chamar Kalil, Lázaro, Marcelo. Virome. Viro minha cabeça e meu corpo, 
esbarrando levemente o joelho em sua cintura, projetando minha vista para além dele, para fora do Caneca de Prata. Ele não se move, o rosto voltado para o maldito espelho que reflete outro espelho na parede atrás de nós. Enquadrinha-me. Ri de mim. Posso jurar, mesmo sem ver. Finjo esperar alguém (LIMA TRINDADE, 2011, p. 403).

A evocação realça o ineditismo do olhar em detalhes, conduzindo passo a passo a presa a quem deseja enlaçar. O sujeito protagonista de seu próprio relato fala de si mesmo na própria ação narrada. Contudo, o que vem à tona é o imaginário do personagem que aponta para uma subjetividade em processo que diz e coloca a imagem a serviço do desejo:

'Oi, eu me chamo James Gandolfini'. Reconheço a voz de Bono e balanço a cabeça no ritmo do som. Ele espera um sinal, uma palavra, um gesto meu. Está de frente para mim. Esperando. Eu despenco. Adio. Faço-me prisioneiro. O pior: capaz de perceber toda a doçura existente nesse homem, sentir seu perfume mesclado ao sabor tenro de um bom charuto. Anoitece em mim. Estamos eu e o árabe juntos. Recordo a cena de um filme, uma página lida em solidão (LIMA TRINDADE, 2011, p. 403-404).

Quer dizer, o personagem se vê, se constrói na ânsia do narrar. Porém, falta palavra. 
E se excede na ação que se reflete no próprio ato de narrar. Por esse feito, James é o ator que, sem palavras, protagoniza sua história, e se vê através dela, dos espelhos que produzem a imagem de si e do outro que mira, mas se percebe no esgotamento da experiência:

O veneno e a palidez de um jovem casal. Vivo neles e eles em mim. Lanço meu apelo, meu pedido de socorro, cego sobre os arranha-céus. Se eu falasse, talvez seguíssemos por um caminho conhecido, seguro. Nós brindariamos sorridentes à madrugada. Nossas palavras se emendariam, completando-nos. Eu mostraria a ele minha casa, as fotos premiadas numa exposição, minha banheira. E, antes do amor, eu secaria suas costas com toalhas felpudas, exibindo toda a minha calma e tranquilidade (LIMA TRINDADE, 2011, p. 404).

Como um parrudo, James realça o pano de fundo em que se desenrola a trama da revelação de um amor que não veio. Ele remete ao modo como o narrador acompanha os aspectos descritos por uma imaginação fértil. Caso este falasse, o ato verbal projetado o lançaria para a iminência do ato sexual. O que descreve com a potência do olho, o baixinho arábe, o sujeito fortinho, como ele, enuncia a força da narrativa, o modo como diz de si, do sujeito que narra, a forma como dirige a narração. Há uma experiência de liberdade, 
justamente por ser urso, no instante em que o relatar surge livremente, sem controle, sem disciplina, enunciando o corpo nu. Por isso, o parrudo é mais do que um significado que atrai e retrai, mas um devir, que reterritorializa a entrega de falar de si, de tudo que colhe e ali vivencia, dizendo algo dele mesmo:

Depois, diria ao meu homem árabe que foi tudo muito mais do que uma boa foda. Ele juraria um amor misturado a choro e bebedeira. Eu acreditaria. Eu quero acreditar. Dividiriamos nossas horas entre filmes em preto e branco e beijos intermináveis. Seria este o cenário. O amor, novamente um clichê. Transformariamos nossas vidas num roteiro ruim (LIMA TRINDADE, 2011, p. 405).

Como na tela do cinema, o protagonista reelabora os códigos, cria uma linguagem sobre a qual constrói a imagem do desconhecido, portando-se como se nunca tivesse existido. O silêncio criado na escrita deduz o mesmo silêncio com o qual James se resigna a não gesticular. A imagem mostra um sujeito absorto do espaço, do acontecimento inesperado:

Estaremos no Caneca de Prata e o calor agitará o ar que espessas nuvens se formem, o vento irrompa sem aviso e grossas gotas de chuva desabem com virulência. É a mesma tempestade que me fez, me faz, aqui, no Caneca de Prata, chamar o garçom e 
pagar a conta, deixando-o ali, sentado no balcão. Tão distante e inalcançável como é belo o azul (LIMA TRINDADE, 2011, p. 405).

Portanto, a obra de Lima Trindade reporta a vivência de um desejo homoerótico que é contado como se fosse a primeira vez, dada a imagem de si a vir por instantes, sem cortar o tesão de olhar o paquera, sem cortar o efeito da ação. Como atuam, como falam e protagonizam os ursos, são questões que a narrativa importa do real, podendo visar ao que é narrado, sua única maneira de condensar os atos de si na imediatez do vivido. São essas as imagens que também a narrativa da escritora Állex Leilla incorpora, com todos os seus predecessores, pois não se trata de expor a si na linha do tempo remediado, e sim de recortar a ação de contar com vistas a repor outros lugares de expressão de outras identidades e que lhe serve de escritura. Assim, as subjetividades homoeróticas, nas obras de Állex Leilla e de Lima Trindade, mais do que revelar a si próprias, são portadas na decorrência de quem e como se enunciam e isso vale mais do que se fala. 


\section{REFERÊNCIAS}

BHABHA, Homi K. O local da cultura. Tradução de Myriam Ávila, Eliana Lourenço de Lima Reis e Gláucia Renata Gonçalves. Belo Horizonte: EDUFMG, 2001.

BAUMAN, Zygmunt. Amor líquido: sobre a fragilidade dos laços humanos. Tradução de Carlos Alberto Medeiros. Rio de Janeiro: Jorge Zahar, 2004.

BUTLER, Judith. Corpos que pesam: sobre os limites discursivos do "sexo". In: LOURO, Guacira Lopes (Org.). O corpo educado: pedagogias da sexualidade. Tradução de Tomaz Tadeu da Silva. Belo Horizonte: Autêntica, 2000.

CAMARGO, Flávio Pereira. Caio Fernando Abreu: um gaúcho além fronteiras. In: SILVA, Antonio de Pádua Dias da (Org.). Literatura contemporânea e homoafetividade. João Pessoa: Editora da UEPB; Realize Editora, 2011.

GIDDENS, Anthony. A transformação da intimidade: sexualidade, amor e erotismo nas sociedades modernas. Tradução de Magda Lopes. São Paulo: EDUNESP, 2003.

GARCIA, Wilton. O corpo espetacularizado. In: LYRA, Bernadette; GARCIA, Wilton. Corpo e cultura. São Paulo: Xamã: ECA-USP, 2001. p. 87-95. 
INÁCIO, Emerson da Cruz. Para uma estética pederasta. In: COSTA, Horácio et al. (Org.). Retratos do Brasil homossexual: fronteiras, subjetividades e desejos. São Paulo: Editora da Universidade de São Paulo; Imprensa Oficial, 2010.

LEILLA, Állex. Henrique. Salvador: Dominio Público, 2001.

ROJAS, Enrique. O homem moderno. São Paulo: Mandarim, 1996.

SENNETT, Richard. Carne e pedra: o corpo e a cidade na civilização ocidental. Tradução de Marcos Aarão Reis. Rio de Janeiro: Record, 2003.

SIMMEL, Georg. A metrópole e a vida mental. Tradução Sérgio Marques dos Reis. In: VELHO, Otavio Guilherme (Org.). O fenômeno urbano. Rio de Janeiro: Zahar, 1967. p. 11-25.

SCOTT, Joan. Prefácio a Gender and Politics of History. Cadernos Pagu. Campinas, v. 3, p. 11-27, 1994.

TRINDADE, Lima. Corações blues e serpentinas. São Paulo: Arte Pau Brasil, 2007.

TRINDADE, Lima. Eu, James Gandolfini (ou Jukebox). In: Nelson Oliveira de Geração Zero Zero: Fricções em Rede. Rio de Janeiro: Lỉngua Geral, 2011. 


\title{
A FORÇA DO DESEJO HOMOERÓTICO INTERSECCIONADO COM QUESTÕES DE RAÇA EM BOM CRIOULO, DE ADOLFO CAMINHA
}

\author{
Rubenilson Pereira de Araujo ${ }^{1}$
}

\begin{abstract}
Nunca experimentara semelhante cousa, nunca homem algum ou mulher produzira-lhe tão esquisita impressão, desde que se conhecia! Entretanto, o certo é que o pequeno, uma criança de quinze anos, abalara toda a sua alma, dominando-a, escravizando-a logo, naquele mesmo instante, como a força magnética de um imã (CAMINHA, 2009, p. 38).
\end{abstract}

Com as palavras textualmente citadas, inicia-se a trama central do romance Bom Crioulo, de Adolfo Caminha, publicado em 1895, mesmo ano em que o escritor irlandês Oscar Wilde foi condenado no tribunal inglês pela ousadia da vivência de "um amor que não

1 Doutorando em Letras: Ensino de Língua e Literatura pelo PPGL da Universidade Federal do Tocantins, onde é professor assistente no curso de Ciências Naturais (Biologia), ministrando as disciplinas concernentes ao campo pedagógico e linguístico. Desenvolve pesquisas sobre os estudos literários na perspectiva de gênero e diversidade sexual, sob a orientação do prof. Dr. Flávio Camargo.

E-mail: 〈rubenilsonaraujo@uft.edu.br>. 
ousou dizer o nome"2. O romance de Caminha é considerado um marco nos estudos sobre o homoerotismo na literatura brasileira, como afirma o pesquisador e militante do movimento LGBT no Brasil, João Silvério Trevisan (2009, p. 9):

[...] num contexto eivado de contradições, Bom crioulo tornou-se o grande mito da literatura brasileira relacionada ao homoerotismo, pois nele aparece, pela primeira vez entre nós, um protagonista homossexual, dentro de uma relação homossexual também protagonística.

Desta forma, podemos afirmar que é "no fim do século XIX que, praticamente, se inaugura o tema da homossexualidade em nossas letras" (BEZERRA; SILVA, 2012, p. 184). A referida obra literária foi produzida no contexto da estética naturalista, influenciada pelo cientificismo da época, à maneira de Émile Zola, que visava expor as mazelas sociais atreladas a uma visão medicalizante. Nesta perspectiva, o homem é visto sob o prisma do determinismo biológico, fruto de seu meio sociocultural. A homossexualidade é representada como uma chaga, patologia instintiva do ser humano, a qual pode emergir em ambientes de homossociabilidades, passivel,

2 Menção à declaração de Oscar Wilde (1854-1900), importante dramaturgo, escritor e poeta irlandês na defesa de Alfred Douglas, seu ex-amante, perante a promotoria e o júri, ao ser solicitado, pelo promotor, para explicar o que significava o título de um poema de sua autoria. 
portanto, de contenção e repressão dos impulsos da natureza humana. Além disso,

[o] naturalismo trouxe o corpo e o sexo para a cena literária, substituindo o amor cortês, praticamente espiritual, das narrativas românticas. Estas mudanças, no entanto, não sinalizam que as personagens homossexuais foram tratadas fora da heteronormatividade. Podemos perceber este fato pelo fim ao qual elas foram destinadas: castigo, decadência, exclusão e morte (BEZERRA; SILVA, 2012, p. 179).

$\mathrm{Na}$ narrativa de Adolfo Caminha, temos dois personagens que protagonizam um relacionamento homoafetivo marcado pelo contraste de seus parceiros, em sua constituição física e origem étnico-racial. Amaro é um ex-escravo, fugitivo ainda em tempos de escravidão, vivendo atualmente no sistema sociocultural recém-libertário, ainda preso à vassalagem de suas origens, porém respeitado em seu meio social pela força física, aliada aos seus instintos, classificados como "animais". Ele se apaixona por Aleixo, um adolescente loiro, de olhos azuis, de personalidade submissa, de origem socioeconômica humilde (família de pescadores), afável e que vivia sob o estigma de não corresponder aos padrões de virilidade masculina e aos serviços físicos braçais, típicos de seu entorno social.

O cenário inicial do romance é o interior de um navio, uma corveta decadente em alto 
mar, pois ambos estavam a serviço da marinha. O ambiente de bordo é marcado pelo trabalho hostil e por uma vida sem privacidade. Este cenário possibilitaria que emergissem os mais diversos desejos libidinosos, no sentido de saciar o erotismo dos corpos masculinos que ali habitavam. O recrutamento de homens favorecia desejos homoeróticos e relações sexuais entre os seres que vivenciavam a solidão em alto mar. Neste sentido, podemos observar cenas de homossociabilidade diversas (SEDGWICK, 1988), marcadas pelos seus códigos específicos de pessoas analfabetas e que dependiam do trabalho braçal para sobreviver.

A corveta encontra-se em visivel declínio, juntamente com o serviço da marinha naquele contexto. O narrador nos dá inicialmente uma descrição lúgubre desse ambiente sombrio:

A velha e gloriosa corveta que pena! já nem sequer lembrava o mesmo navio d'outrora, sugestivamente pitoresco, idealmente festivo, como um galera de lenda, branca e leve no mar alto, grimpando serena o corcovo das ondas!... (CAMINHA, 2009, p. 25).

O ambiente descrito antecipa o desfecho de um enredo trágico, devido à ênfase na descrição mórbida, decadente e agourenta do cenário. Essa descrição termina no fim do terceiro parágrafo com um sinal de reticências, possivelmente indicando ao leitor que por mais precisa que pudesse ser a descrição da decadência, ainda não retrataria toda a hostilidade 
presente no ambiente que antes foi cenário de glórias e vivacidades.

Ainda no início da narrativa, podemos acompanhar que, em meio à convivência interpessoal, tipicamente masculina, as personalidades, consideradas "diferentes" em suas homossociabilidades interpessoais, são veementemente rechaçadas, estereotipadas com atribuição de nomes pejorativos e também excluídas por palavras de injúrias ou difamações específicas do meio denominado de "macho" pelos operários da marinha.

A injúria atribuida aos atos desviantes cometidos pela heteronormatividade naturaliza a homofobia no local e faz com que as personagens vivenciem "a experiência do insulto (sem falar até da agressão física) [sendo] um dos traços mais comuns de suas existências" (ERIBON, 2008, p. 30). A discriminação verbal é uma forma de apontar a diferença porque o corpo é representado como um objeto passivel de injúria e castigos físicos.

Desta maneira, em um ambiente marcado por violências físicas, assemelhandose a um suposto sadomasoquismo, podemos acompanhar a sentença promulgada por um ato ilicito de um corpo:

Ora, aconteceu que, na véspera desse dia, Herculano foi surpreendido, por outro marinheiro, a praticar uma ação feia e deprimente do caráter humano. Tinham-no encontrado sozinho, junto à amurada, em pé, a mexer com o braço numa posição torpe, 
cometendo, contra si próprio, o mais vergonhoso dos atentados (CAMINHA, 2009, p. 33).

A cena pela qual o personagem Herculano será punido sugere um ato de masturbação, o qual era passivel de vigilância e punição, segundo o contrato social de convivência estabelecido no ambiente em questão. Notamos, portanto, o caráter de vigiar e punir os corpos a fim de adestrá-los (FOUCAULT, 2006), contendo os seus impulsos instintivos para continuar sendo um corpo dócil ao sistema de produção do trabalho na marinha. O narrador adjetiva essa ação natural como "feia", "deprimente do caráter humano" e o "mais vergonhoso dos atentados". Sequenciando a narrativa, defrontamo-nos com outras descrições, como:

[...] No convés brilhava a nódoa de um escarro ainda fresco: Herculano acabava de cometer um verdadeiro crime não previsto nos códigos, um crime de lesa natureza, derramando inutilmente no convés seco e estéril, a seiva geradora do homem (CAMINHA, 2009, p. 33).

Nestas descrições, podemos perceber nitidamente a visão reducionista da sexualidade humana, concebida apenas com fins para a reprodução da espécie, inviabilizando a possibilidade de se enxergar, no ato sexual, a possibilidade de prazer, deleite ou realização de base erótica do corpo. Na continuidade das seções públicas de torturas físicas 
dos corpos, os quais são milimetricamente sentenciados (150 chibatadas), esta situação vivenciada pelos personagens em questão no interior do navio nos leva a crer que objetiva à produção de mão de obra "barata" para o sistema servil da marinha em decadência, afinal, "o controle disciplinar dos corpos e dos gestos leva à produção de corpos dóceis, de corpos inteligiveis" (CAMARGO, 2013, p. 15). Notamos que, em cada ato e/ou ritual solene de punição, há a confissão verbal expressa pelo acusado do por que da pena recebida. Este fato nos remonta ao que Foucault discorre sobre a confissão dos sujeitos, prática estabelecida pelos dogmas da Igreja Católica, corrente nos séculos XVIII e XIX.

$\mathrm{Na}$ sequência, aparece o nosso protagonista "Amaro", como o terceiro a ser torturado pelas chibatadas por algum ato não condizente com os códigos de convivência em alto mar. O narrador introduz o personagem descrevendo-o da seguinte forma:

Seguia-se o terceiro preso, um latagão de negro, muito alto e corpulento, figura colossal de cafre, desafiando, com um formidável sistema de músculos, a morbidez patológica de toda uma geração cadente e enervada, e cuja presença ali naquela ocasião, despertava grande interesse e viva curiosidade: era o Amaro, gajeiro da proa o BOM CRIOULO na gíria de bordo (CAMINHA, 2009, p. 35 - grifos do autor). 
Notamos, na descrição que entroniza o nosso protagonista na narrativa, a contradição em relação à adjetivação atribuída ao mesmo, ou seja, após as descrições de "figura colossal" e do "sistema de músculos", que despertam notoriedade pelos demais, ele é denominado como "Bom Crioulo", provavelmente devido aos seus atributos psicológicos de urbanidade, em virtude da domesticação e/ou adestramento que a dita "civilização branca" impôs a ele para a convivência social. Entretanto, segundo o desenrolar da narrativa, o mesmo é impelido por uma força descomunal quando ingere bebidas alcóolicas.

Esse fato nos remonta à mitologia do "bom selvagem" , domesticado pela raça branca eurocêntrica, que marca o seu lugar hegemônico na classificação da raça negra/indigena como subalterna e inferior. Na demarcação da identidade, notamos, nesse contexto exemplificado, que há o marco de uma relação de poder, onde o primeiro é detentor da condição de dominador e o outro é colocado à margem, na condição de dominado, relegado ao patamar de inferioridade.

Em toda a trama narrativa, notamos os corpos sendo punidos fisicamente a fim de

30 suíço Jean-Jacques Rousseau, filósofo e escritor de origem francesa, conviveu com os maiores expoentes do Iluminismo. Ele é considerado o precursor do Romantismo pela criação do mito do "bom selvagem". Convencido de que o homem é bom por natureza, sendo o viver em sociedade a causa da sua degradação moral, passou a condenar o estudo das ciências e a prática das artes. Privilegiando o naturalismo, o primitivismo e os costumes indígenas, tornou-se um implacável crítico da organização social. 
serem adestrados, tornando-os úteis e servis. Historicamente, os castigos focalizam como objeto o corpo, com a intenção de controlar suas forças para atender o ideal preconizado, pois

as relações de poder têm alcance imediato sobre ele; elas o investem, o marcam, o dirigem, o supliciam sujeitam-no a trabalhos, obrigam-no a cerimônias, exigem-lhe sinais (FOUCAULT, 1997, p. 28)

porque, mediante tais práticas, "o corpo só se torna útil se é ao mesmo tempo, produtivo e corpo submisso" (FOUCAULT, 1997, p. 28). Podemos afirmar ainda que, na narrativa em questão, "o flagelo do corpo dos sentenciados indica que privilegiar os prazeres da carne é um mau caminho e merece castigo" (BEZERRA; SILVA, 2012, p. 180).

A causa que levou Amaro à prisão e à execução do castigo foi justamente seu interesse pelo grumete Aleixo:

O motivo, porém, de sua prisão agora, no alto mar, a borda da corveta, era outro, muito outro: Bom-Crioulo esmurrara desapiedadamente um segunda-classe, porque este ousara, sem o seu consentimento, maltratar o grumete Aleixo, um belo marinheirito de olhos azuis, muito querido por todos e de quem diziam-se cousas (CAMINHA, 2009, p. 37). 
Neste momento da narrativa, acompanhamos o sofrimento de Amaro, o qual é submetido, no final do primeiro capítulo, a um total preciso de 150 chibatadas, embora tal martírio the causasse certo prazer devido ao fato de essa pena ser em virtude do objeto de seu desejo erótico - Aleixo, o qual ainda não aparece na narrativa, mas apenas é mencionado pelo narrador que o insere posteriormente. Aleixo, introduzido na narrativa como prestador de serviços tipicamente femininos, sendo proveniente do sul do estado de Santa Catarina, é representado como o arquétipo oposto de Amaro, o qual já nutre sentimentos de afeto por ele, desde o primeiro encontro. Vale ressaltar que a homossexualidade sugerida visivelmente nos traços do personagem é tratada como "diziam-se cousas", ou seja, prevalece "o recurso do indizivel" (BEZERRA; SILVA, 2012) do provável relacionamento amoroso "que não ousará dizer o nome", devido à deslegitimação sociocultural vigente.

A atração física dos amantes, envoltos em seções semelhantes ao sadomasoquismo, vivenciadas nas viagens a bordo da corveta, e a atração fatal entre os dois opostos, em sua estrutura corpórea, continua até culminar no ato sexual em si, onde podemos notar, explicitamente, o tratamento da visão patologizante acerca da homossexualidade:

Uma sensação de ventura infinita espalhava-se-lhe em todo o corpo. Começava a sentir no próprio sangue impulsos nunca experimentados, 
uma como vontade ingênita de ceder aos caprichos do negro, de abandonar-se-lhe para o que ele quisesse uma vaga distensão dos nervos, um prurido de passividade. . .

- Ande logo! murmurou apressadamente, voltando-se.

E consumou-se o delito contra a natureza (CAMINHA, 2009, p. 30 - grifo nosso).

Como percebemos nessa citação, o ato (homo)sexual é descrito assemelhando-se a um rito de iniciação que se dá pela culminância do desejo erótico entre os corpos que se veem conduzidos por uma força instintiva até culminar na ação de enlace sexual. Porém o autor a nomeia explicitamente de "delito contra a natureza”. Notamos nitidamente, nessa passagem, a força de noções socioculturais de uma sociedade que não consegue conceber o desejo erótico e sexual entre pessoas do mesmo sexo. Podemos notar, na concretização do ato em si, a fissura do que está arraigado socioculturalmente em relação ao binarismo estabelecido.

Na descrição anterior, notamos uma força instintiva levando Aleixo a uma postura passiva no ato sexual, como se uma força maior o detivesse ao ato de passividade. Tal leitura leva-nos ainda a refletir que o desejo íntimo encontra-se em um patamar superior à anatomia corpórea, a ponto de alterar a corrente sanguínea e deixar-se levar pela vontade que se mostra maior do que as prescrições socialmente estabelecidas. 
O início do relacionamento de Amaro com Aleixo faz desencadear o processo de regressão de um corpo dócil, moldado para atender ao sistema de produção militar e, gradativamente, o Bom Crioulo vai perdendo as destrezas e os bons costumes adquiridos no contato com a civilização:

[...] insinuavam que Bom-Crioulo tornara-se assim, esquecido e indiferente, dês que se metera com o Aleixo, o tal grumete, o belo marinheirito de olhos azuis, que embarcara no sul. O ladrão do negro estava mesmo ficando sem vergonha! (CAMINHA, 2009, p. 46).

Em meio aos olhares e às criticas vigilantes, a narrativa sobre o relacionamento de Amaro com Aleixo prossegue. O corpo de Aleixo vai sendo moldado por Amaro, com presentes e adornos, inclusive um dos primeiros presentes que Amaro oferece a Aleixo é um espelho "barato", o que o faz sentir-se feliz com a sua autoimagem refletida. Este fato remonta-nos à analogia com o mito de $\mathrm{Narciso}^{4}$, pois Aleixo assume a sua beleza fisica segundo os padrões socioculturais vigentes. Amaro promete-lhe coisas boas, gabase de "conhecer o mundo" e lhe faz interessantes promessas para quando chegarem à cidade do Rio de Janeiro, como passeios no teatro, no

\footnotetext{
40 mito de Narciso representa (senão para os gregos ao menos para nós) o drama da individualidade"; "ele mostra, isto sim, a profundidade de um indivíduo que toma consciência de si mesmo" em si mesmo e perante a si mesmo, ou seja, no Lugar onde experimenta os seus dramas humanos (SPINELLI, 2006, p. 99).
} 
Pão de Açúcar, nos casarões, nos palácios etc., incluindo-se a promessa de morarem juntos na Rua da Misericórdia. Estas promessas de Amaro a Aleixo nos remetem ao imaginário sociocultural do relacionamento homoerótico marcado por bonificações financeiras, "o amor de bolso", como uma espécie de ressarcimento pelos afetos dispensados ao corpo homossexual.

Outro fato interessante é o deslocamento, a fuga do local restrito para a cidade a fim de vivenciar um amor proibido pelas normas heterossexuais. De acordo com Eribon (2008, p. 31-33), "a cidade sempre foi o refúgio dos homossexuais" e "a homossexualidade tem ligação com a cidade”. Seria como se a cidade possibilitasse uma convivência amorosa com mais privacidade íntima e menos vigilância e punição dos olhares alheios.

Ao deparar-se com o porto de chegada, destino dos amantes, na cidade do Rio de Janeiro, Amaro discorre sobressaltado pela força impetuosa de uma paixão, totalmente envolto em questionamentos de insegurança, fragilidade, e contradição a respeito dos sentimentos que nutre pelo ente amado e também acerca de seus desejos. Amaro, inclusive, se autoquestiona sobre a sua orientação sexual, atribuindo-lhe uma espécie de castigo, ato pecaminoso ou algo semelhante:

Ao pensar nisso Bom-Crioulo sentia uma febre extraordinária de erotismo, um delírio invencivel de gozo pederasta... Agora compreendia que só no homem, no próprio homem, ele 
podia encontrar aquilo que debalde procurara nas mulheres. Nunca se apercebera de semelhante anomalia, nunca em sua vida tivera a lembrança de perscrutar suas tendências em matéria de sexualidade. [...] E o mais interessante é que aquilo ameaçava ir longe, para mal de seus pecados... Não havia jeito, senão ter paciência, uma vez que a natureza impunha-lhe esse castigo [...] De qualquer modo estava justificado perante sua consciência, tanto mais quanto havia exemplos ali mesmo a bordo, para não falar em certo oficial de quem se diziam cousas medonhas no tocante à vida particular. Se os brancos faziam, quanto mais os negros! É que nem todos têm força para resistir: a natureza pode mais que a vontade humana... (CAMINHA, 2009, p. 66).

No excerto anterior, podemos perceber toda a concepção sociocultural a respeito da heterossexualidade compulsória, a qual impõe o binarismo como única alternativa para a orientação sexual do indivíduo. O que foge de tal destino seria a sexualidade desviante, atribuída à ideia de patologia e/ou transtorno psiquiátrico. Nessas reflexões, notamos a condição subalterna da raça negra, sempre considerada como vassala e dependente da hegemonia branca e tudo isso em contrapartida de um simples e natural desejo humano que aflora na personalidade de uma pessoa cônscia de 30 anos.

Em uma época marcada pela escravidão, 
a condição considerada inferior da raça negra condiciona Amaro, socialmente, a uma espécie de animalização. Ele se encontra em uma situação de subjetivação, absorto em seus conflitos interiores, os quais nos levam a concluir que ele "sempre é suscetivel de ser anulado, desvalorizado, ridicularizado ou simplesmente explicado e reduzido ao estado de objeto pelas categorias do discurso dominante" (ERIBON, 2008, p. 74). Tal fato acentua-se ainda mais na intersecção dos preconceitos raciais e de gênero, na condição de negro e homossexual, dupla estigmatização social, pois, na discriminação racial, o estigma está na pigmentação externa da pele, enquanto na orientação sexual, está o desejo interno, intrínseco ao sujeito.

No quinto capítulo da narrativa, o outro cenário onde se encontram os amantes (quarto alugado de D. Carolina, na Rua da Misericórdia, no Rio de Janeiro), semelhantemente ao primeiro ambiente onde se inicia a trama romanesca (a corveta), mais uma vez o ambiente decadente inspira certo agouro para o desfecho do caso de amor. Se aquele é comparado a um abutre, nesse, ronda a notícia de uma morte recente do ex-inquilino. Em certos momentos de descrição das cenas amorosas dos amantes homossexuais, notamos desejos animalizados e incomuns:

Uma cousa desgostava o grumete: os caprichos libertinos do outro. Porque Bom-Crioulo não se contentava em possuí-lo a qualquer hora do dia ou da noite, queria muito mais, obrigava 
-o a excessos, fazia dele um escravo, uma mulher-a-toa propondo quanta extravagância lhe vinha à imaginação. Logo na primeira noite exigiu que ele ficasse nu, mas nuzinho em pêlo: queria ver o corpo...

Dentro do negro rugiam desejos de touro ao pressentir a fêmea... Todo ele vibrava, demorando-se na idolatria pagã daquela nudez sensual como um fetiche diante de um símbolo de ouro ou como um artista diante duma obra-prima. Ignorante e grosseiro, sentia-se, contudo, abalado até os nervos mais recônditos, até às profundezas do seu duplo ser moral e físico, dominado por um quase respeito cego pelo grumete que atingia proporções de ente sobrenatural a seus olhos de marinheiro rude (CAMINHA, 2009, p. 78-80).

De modo geral, Amaro, enquanto individuo mais maduro, nutre por Aleixo um verdadeiro sentimento de encanto, fascinação e obsessão. Em contrapartida, provavelmente devido a uma suposta imaturidade ou inadaptação a tal prática sexual, a correspondência por parte de Aleixo não é tão reciproca. Um fato interessante a observar a respeito da representação da homossexualidade pelo narrador são as consequências de uma "heteronormatividade compulsória" (RICH, 1980), visto que a dualidade entre ativo versus passivo prevalece na narrativa, além da oposição da estrutura física dos corpos dos amantes, levando Amaro à verdadeira veneração pelos atributos frágeis e afeminados de seu parceiro Aleixo. 
O relacionamento e a atração física desencadeiam-se em analogia semelhante a uma relação homem/mulher e não entre dois corpos do mesmo sexo masculino:

Amaro trata Aleixo como se trata uma mulher; as caracteristicas que descreve e admira nele são atributos femininos [...] Ao contemplar o jovem, Amaro o vê como uma mulher, nunca como um homem; com o receio da traição de Aleixo, o negro pensa que o adolescente pudesse vir a traí-lo com outro homem, jamais com uma mulher (OLIVA, 2012, p. 220).

O narrador defende a tese de que os instintos de Amaro são selvagens e os seus desejos, considerados doentios, visto que ele é duplamente estigmatizado: negro e homossexual, na sociedade de final do século XIX, contradizendo o protótipo de indivíduo social e hegemonicamente aceito na época (e até nos dias atuais): branco, cristão, de classe média, de origem europeia e heterossexual. Amaro continuava trabalhando duro na corveta para manter as obrigações de provedor da casa, o seu corpo ia se definhando a cada dia, enquanto Aleixo, sempre muito bem cuidado, encorpava-se significativamente. Ele ia adquirindo dia a dia características mais masculinas, deixando de lado a sua feminilidade.

O que o Bom-Crioulo não sabia era a intenção da proprietária da casa, D. Carolina, que começava a planejar uma intervenção para o caso tornar-se um triângulo amoroso: 
Há dias metera-se-lhe na cabeça uma extravagância: conquistar o Aleixo, o bonitinho, toma-lo para si, tê-lo como amantezinho do seu coração avelhentado e gasto, amigar-se com ele secretamente, dando-lhe tudo quanto fosse preciso: roupa, calçados, almoço e jantar nos dias de folga dando-lhe tudo enfim (CAMINHA, 2009, p. 89).

D. Carolina projeta, no jovem Aleixo, a concretização de seus desejos eróticos, visto o mesmo mostrar-se ainda inexperiente e passível de modelá-lo como o amante ideal. Daí, ela planeja sua ação e, determinado dia, na ausência do Bom-Crioulo, após um passeio de Aleixo, concretiza a sua intenção no interior de seu quarto previamente preparado:

Entra, filhinho, entra, que isto aqui é nosso, isto aqui é da tua portuguesinha, não vês?

$\mathrm{E}$, alegre como nunca, foi abrindo as janelas que diziam para a Rua da Misericórdia, num alvoroço. Enquanto o pequeno andava fora, ela fizera nova toilette, penteara-se, mudara a roupa, trocara os tamancos por umas sapatinhas cor de sangue e colocara os anéis, os célebres anéis que lhe tinham querido roubar: transformarase completamente.

Senta, deixa de tolice, filho!

Aleixo sentou-se muito acanhado, com um ar de colegial que pela primeira vez penetra num lugar suspeito. [...]. O contato de sua perna com a 
da portuguesa produzia-lhe um calorzinho especial, um brando enleio d'alma, uma vaga e deliciosa canseira no fundo do ser, um esquisito bem-estar $[\ldots]$

O efebo teve um arranco de novilho excitado, e, segurando-se à cadeira com as mãos ambas, todo trêmulo agora $[\ldots]$

Então ela, como se lhe houvessem aberto de repente uma caudal de gozo, cravou os dentes na face do grumete, numa fúria brutal, e segurando-o pelas nádegas, o olhar cintilante, o rosto congestionado, foi depô-lo na cama (CAMINHA, 2009, p. 91-94).

Na descrição minuciosa desta cena, comparada com o primeiro ato sexual ocorrido entre o casal Amaro e Aleixo, notamos explicitamente atos de iniciação de um corpo nas práticas de sexualidade ativa, em que o narrador não poupa detalhes de um desejo erótico que sobressalta o ser humano, independentemente da orientação sexual, idade ou posição social. Em ambos os momentos (homossexual e heterossexual), Aleixo demonstra-se inexperiente em determinada prática sexual, apresentando nítidos traços de passividade e submissão aos desejos eróticos do/a parceiro/a.

Tais fatos indicam a constituição de uma narrativa de formação em que o grumete acaba incluso nas regras sociais heteronormativas que lhe são impostas, porque se envolveu com o sexo oposto e de origem racial semelhante à sua, passando a ter ojeriza íntima 
ao antigo parceiro sexual. Ao mesmo tempo, Aleixo permite observar facetas da diversidade sexual humana, a qual emerge numa provável bissexualidade da personagem, que estabelece a possibilidade de "trânsito de uma identidade de gênero para outra" (OLIVA, 2012, p. 217).

O triângulo amoroso prossegue às escondidas, mas quando Amaro volta do trabalho intenso na velha corveta, com saudades do amante, foge para o velho quarto da Rua da Misericórdia, a fim de reencontrá-lo, mas não o encontra em casa e, desapontado, começa a nutrir suspeitas de ciúmes pela possibilidade de um terceiro elemento do mesmo sexo no relacionamento homoerótico. Amaro envolve-se em confusões e/ou contendas devido à ingestão de bebidas alcoólicas, visto que toda vez que se embriagava, entrava em pleno descontrole de suas faculdades humanas. Envolveuse em lutas que duraram horas com a polícia, culminando em sua prisão, já bastante machucado fisicamente.

Bom-Crioulo, sentindo-se solitário e abandonado no ambiente hostil do hospital, ansiava pela visita de Aleixo que, porém, estava verdadeiramente enamorado pela portuguesa e satisfazia com ela as suas fantasias sexuais mais intimas. Ele sentia pena de Amaro, devido aos favores obtidos ao longo da vida, e, ao mesmo tempo, um verdadeiro nojo das intimidades vividas entre ambos. $\mathrm{O}$ hospital, para Amaro, assemelhava-se a um inferno, os dias eram longos e as noites, intermináveis. Os espaços reservados para o 
cenário do desenlace do romance são fechados, sombrios e se constituem como íntimos, privados do público em geral, pois

[assim] como a corveta e o quarto, o hospital é também um espaço de reclusão, pois todos estão localizados à distância do espaço público. Quando a relação vivida por eles chega à rua é para ter o seu fim decretado e selado com a morte. A rua é o cenário no qual as cortinas do teatro amoroso homoerótico se fecham (BEZERRA; SILVA, 2012, p. 183).

D. Carolina mesma foi quem impediu a comunicação entre Amaro e Aleixo, orientando esse a não visitar aquele cujo ressentimento se marca pelo desejo possessivo, doentio, uma espécie de "amódio" (misto de amor e ódio) que o interpela. Após fugir do hospital, quando chega à Rua da Misericórdia, "BomCrioulo ficou imóvel, calado, perdido nas suas ideias. Aleixo amigado com a portuguesa, com a D. Carolina! Era inacreditável, era um desaforo sem nome, um desrespeito, uma falta de vergonha, um escândalo!" (CAMINHA, 2009, p. 154). Quando os ex-amantes se encontram, o diálogo é tenso, presenciado por uma multidão que ignora o protagonista, e deixa o corpo ensanguentado do grumete inerte e sem vida. 


\section{Considerações finais}

O romance Bom Crioulo, de Adolfo Caminha (1895), é uma obra clássica, considerada pioneira nos estudos homoeróticos na literatura brasileira, devido ao fato de apresentar, na trama central, um relacionamento homoerótico. Prevalece em toda a narrativa uma reiteração da homossexualidade, compreendida e representada discursivamente a partir de um ponto de vista patológico, característico de uma época marcada pelo cientificismo e pela descoberta das mazelas sociais na estética literária denominada Naturalismo.

Além disso, podemos verificar o posicionamento discriminatório e preconceituoso do narrador, assim como os valores depreciativos referentes às práticas discursivas de subjetivação dos dois personagens. Nesse sentido, a homossexualidade é associada a uma perspectiva pejorativa a partir de um processo de subalternização dos personagens homoafetivos, cujo desejo é alijado na e pela sociedade da época, impondo a Amaro e a Aleixo uma degradação moral e social.

$\mathrm{Na}$ trama do romance, verificamos um mundo de injúrias, destinado aos corpos dos personagens homossexuais, objetos de poder e de manipulação. Além disso, a intersecção de estigmas de gênero e raça, sofridos por Amaro, o qual é duplamente estigmatizado pelas condições de ser negro e homossexual em uma sociedade hipócrita, regulada pelo preconceito explícito e pelas normas de uma heterossexualidade compulsória. 


\section{REFERÊNCIAS}

BEZERRA, Carlos Eduardo; SILVA, Telma Maciel. Os destinos das personagens homossexuais: recortes no panorama literário brasileiro do final do século XIX ao início do século XX. In: MOREIRA, Adailson, BEZERRA, Carlos Eduardo; SILVA, Telma Maciel da (Org.). Arco-íris revisitado: diversidade sexual em pauta. Porto Alegre: Escândalo, 2012.

CAMARGO, Flávio Pereira. Novas configurações familiares na literatura brasileira infantil e juvenil: leitura de Meus dois pais, de Walcyr Carrasco, e de Olivia tem dois papais, de Márcia Leite. In: CONGRESSO INTERNACIONAL DE ESTUDOS LINGUÍSTICOS E LITERÁRIOS NA AMAZÔNIA (CIELLA), 4., 2013, Belém. Anais... Belém: [s.n.], 2013. p. 1-12

CAMINHA, Adolfo. Bom Crioulo. Rio de Janeiro: Edições de Ouro, 2009.

ERIBON, Didier. Reflexões sobre a questão gay. Tradução de Procópio Abreu. Rio de Janeiro: Companhia de Freud, 2008.

FOUCAULT, Michel. Ética, sexualidade e politica. Tradução de Elisa Monteiro; Inês Autran Dourado Barbosa. Rio de Janeiro: Forense Universitária, 2006. 
FOUCAULT, Michel. Vigiar e punir: nascimento da prisão. Tradução de Raquel Ramalhete. Petrópolis: Vozes, 1997.

OLIVA, Osmar Pereira. A terceira margem do desejo: Bom-Crioulo e O Barão de Lavos. In: MOREIRA, Adailson, BEZERRA, Carlos Eduardo; SILVA, Telma Maciel da (Org.). Arco-iris revisitado: diversidade sexual em pauta. Porto Alegre: Escândalo, 2012. p. 215-232.

RICH, A heterossexualidade compulsória e a existência lésbica. Tradução de Carlos Guilherme do Valle. Revista Bagoas, Natal, n. 5, p. 17-44, 2010. Disponível em: <http:/ / www.cchla.ufrn.br/bagoas/v04n05art01_rich. pdf $>$. Acesso em: 5 abr. 2009.

SEDGWICK, Eve Kosofsky. Between Men. In: RIKVIN, J.; RYAN, M. (Ed.) Theory of Literature: an Anthology. Oxford: Blackwell, 1998.

TREVISAN, João Silvério. Introdução à obra Bom Crioulo, de Adolfo Caminha. São Paulo: Hedra, 2009. 


\title{
REPRESENTAÇÃO DISCURSIVA DA DIVERSIDADE SEXUAL EM O GATO QUE GOSTAVA DE CENOURA, DE RUBEM ALVES
}

\author{
Vanessa Rita de Jesus Cruz $^{1}$ \\ Flávio Pereira Camargo ${ }^{2}$
}

\section{Curriculo, diversidade sexual e ensino de literatura infantil}

A escola e o professor constituem-se como mediadores da criança e do adolescente com o conhecimento e com o mundo que o cercam. Por isso, devemos estar atentos para as noções, os conceitos, as ideias e os valores que pregamos e perpetuamos como corretos. Conhecimento, poder e identidade social estão intimamente relacionados. Como não poderia ser diferente, em se tratando da educação, o currículo não fica aquém da produção do social. Conforme Tomaz Tadeu da Silva (2009), não apenas o currículo,

1 Mestre em Ensino de Língua e Literatura pela Universidade Federal do Tocantins/Campus de Araguaína. É professora efetiva de Língua Portuguesa e Literatura da rede estadual de ensino do Estado do Tocantins.

E-mail: 〈vanessalinguagens@hotmail.com〉

2 Pós-doutor em Estudos Literários pela UFMG. Doutor em Literatura pela UnB. Doutor e Mestre em Letras e Linguística (Estudos Literários) pela UFG. Atualmente, é professor de Literatura Brasileira da UFT/Campus Universitário de Araguaína, atuando na graduação e no Programa de Pós-Graduação em Letras. E-mail: 〈camargolitera@gmail.com〉. 
mas o próprio discurso sobre o currículo está implicado nos processos que regulam e governam a conduta humana. Ele - o discurso - constitui um dos elementos que ligam o saber e o poder, de que fala Foucault.

Ainda segundo Silva (2009), retomando Foucault, as modernas formas de governo precisam conhecer a população a ser governada, para melhor controlá-la. As estratégias de controle não são apenas externas; pretende-se também o autogoverno dos indivíduos, tendo em vista a democracia. Têm-se as estratégias para se conhecer os individuos, mas eles também precisam conhecer a si mesmos para se autogovernar.

A área do currículo representa uma das formas de conhecimento dos individuos, implicadas em estratégias de poder:

A Teoria do Currículo consiste precisamente nisso: em formular formas de melhor organizar experiências de conhecimento dirigidas à produção de formas particulares de subjetividade: seja o sujeito conformista e essencializado das pedagogias tradicionais, seja o sujeito 'emancipado' e 'libertado' das pedagogias progressistas. A Teoria do Currículo é uma espécie muito especial de tecnologia de governo, na medida em que seu saber específico não lida apenas com um conhecimento sobre o indivíduo (como a Psicologia, por exemplo), mas com um conhecimento sobre os nexos entre conhecimento e indivíduo (SILVA, 2009, p. 192 - grifos do autor). 
Dessa maneira, a Teoria do Currículo, a partir do objetivo de produzir uma subjetividade determinada, tenta identificar quais conhecimentos, atitudes e valores são necessários e adequados para obter essa subjetividade. O currículo pretende produzir sujeitos particulares; a Teoria do Currículo, por sua vez, busca a melhor maneira de produzi-los (SILVA, 2009). Vemos que o que está em jogo é a produção de identidades legítimas e inteligíveis. A Teoria do Currículo, que deveria prestar-se a criticar os currículos existentes, zelar pela emancipação e libertação, está relacionada com as estratégias de poder que pretendem regular e governar os sujeitos.

Não podemos negar o caráter histórico e político do currículo: variadas atividades podem ser feitas por meio dele, considerando-se a época e o contexto. Mas ele possui também um caráter social, haja vista que se produz conhecimento na relação entre as pessoas. Aqui, abrimos espaço para pontuar a ressalva que faz Silva (2009, p. 194) ao afirmar que "é importante ver o currículo não apenas como sendo constituído de 'fazer coisas' mas também vê-lo como 'fazendo coisas às pessoas"' (grifos...). Ora, o currículo não deve ser visto apenas como ações - aquilo que fazemos com os materiais recebidos -, mas há de se considerar também os seus efeitos - aquilo que ele nos faz. Esses dois sentidos estão permeados de relações de poder. Mesmo considerando essas relações, se agimos sobre o currículo, podemos desviar, subverter e contestar esses 
materiais, porém, como já dissemos, não apenas produzimos o currículo, também somos produzidos de formas específicas por relações de poder. O currículo constitui sujeitos particulares e demarca o seu posicionamento nas divisões sociais.

O que vem descrito no currículo, de forma explícita ou implicita, expressa, de forma particular, noções sobre conhecimento, sobre a organização da sociedade e seus diferentes grupos. As narrativas ali contidas

[...] dizem qual conhecimento é legítimo e qual é ilegitimo, quais formas de conhecer são válidas e quais não o são, o que é certo e o que é errado, o que é moral e o que é imoral, o que é bom e o que é mal, o que é belo e o que é feio, quais vozes são autorizadas e quais não o são. As narrativas contidas no currículo trazem embutidas noções sobre quais grupos sociais podem representar a si e aos outros e quais grupos sociais podem apenas ser representados ou até mesmo serem totalmente excluídos de qualquer representação. Elas, além disso, representam os diferentes grupos sociais de forma diferente: enquanto as formas de vida e a cultura de alguns grupos são valorizadas e instituídas como cânon, as de outros são desvalorizadas e proscritas (SILVA, 2009, p. 195).

A partir dessa citação, podemos perceber como as narrativas do currículo fixam noções específicas sobre classe, etnia, gênero 
e sexualidade e como seus discursos podem autorizar ou desautorizar, legitimar ou deslegitimar, incluir ou excluir. Logo, o currículo é, de certa forma, o responsável por quem nos transformamos. Se, por um lado, para governar, dispor de poder, é preciso conhecer; por outro lado, o saber não está livre dos efeitos do poder. O currículo, como conjunto de saberes, está ligado ao poder. Este é que seleciona, inclui, exclui, produz e reforça os conhecimentos, os grupos sociais e os modelos válidos. O que podem, então, a escola e o professor fazer diante dessas relações de poder e divisão, que supervaloriza algumas identidades e conhecimentos e subjuga os "outros"?

Dentre as identidades que vivem subjugadas pelas relações de poder estão a sexual e a de gênero. Segundo Foucault (1988), é comum dizer que a época clássica submeteu o sexo das crianças à ocultação. O autor ressalta que se continuou a falar do sexo, porém de outras formas, por outras pessoas, com outros pontos de vistas, com a intenção de se obter outros efeitos. Por isso, devemos estar atentos ao não dito, à forma como eram divididos os que estavam autorizados a dizer e os que não podiam falar e o que podiam falar, que grau de discrição era exigido de uns e de outros. Os muitos silêncios permeavam e apoiavam os discursos.

Para Foucault (1988), os colégios do século XVIII, por meio de seus dispositivos arquitetônicos, os regulamentos das disciplinas e a organização interior, falavam de sexo continuamente: 
Os organizadores levaram-no (o sexo) em conta de modo permanente. Todos os detentores de uma parcela de autoridade se colocam num estado de alerta perpétuo: reafirmando sem trégua pelas disposições, pelas precauções tomadas, e pelo jogo das punições e responsabilidades. O espaço da sala, a forma das mesas, o arranjo dos pátios de recreio, a distribuição dos dormitórios (com ou sem separações, com ou sem cortina), os regulamentos elaborados para a vigilância do recolhimento e do sono, tudo fala da maneira mais prolixa da sexualidade das crianças (p. 34).

O discurso institucional constatava a sexualidade, precoce, ativa e permanente. A sexualidade do colegial, ao longo do século XVIII, torna-se um problema público: médicos aconselham diretores e professores das instituições, assim como as famílias; os pedagogos realizam projetos e os professores se dirigem aos seus alunos com recomendações e para os mesmos escrevem livros contendo conselhos médicos e exemplos que edificam.

Por tudo isso, Foucault (1988) nos diz que a instituição pedagógica não impôs um silêncio ao sexo das crianças e dos adolescentes. Desde o século XVIII, os seus discursos tratam desse tema. Nesse mesmo século e no seguinte, entram em cena outros focos que também produzirão os discursos sobre o sexo: a medicina, a psiquiatria e a justiça penal. A partir daí, ao longo dos tempos, os controles sociais filtram a sexualidade da so- 
ciedade: casais, pais, filhos, crianças e adolescentes, protegendo, separando e prevenindo, "solicitando diagnósticos, acumulando relatórios, organizando terapêuticas" (p. 37).

Os diferentes discursos eram produzidos onde residia o poder e eram um meio para o seu exercício. Em toda parte, incita-se o falar sobre o sexo, mas também se criam os dispositivos para que se ouça e se registre, para que se observe, interrogue e formule. Ele ganha existência discursiva. Discursos proferidos por diferentes instituições ganham forma, segundo Foucault (1988), na demografia, na biologia, na medicina, na psiquiatria, na psicologia, na moral e na crítica politica. Os três últimos séculos caracterizam-se pela variedade de meios criados para que dele se pudesse falar, para que ele falasse, para que se pudesse escutar, registrar e redistribuir aquilo que se dizia sobre o sexo.

Havia, até o final do século XVIII, três códigos explícitos que regiam as práticas sexuais: o direito canônico, a pastoral cristã e a lei civil. Eles determinavam o lícito e o ilícito. Estavam voltados para as relações matrimoniais, que eram permeadas de regras e de recomendações, portanto, ir contra as leis do casamento ou ater-se a prazeres estranhos era motivo de condenação. Os tribunais condenavam a homoafetividade, a infidelidade, o casamento sem a permissão dos pais e a bestialidade. A lei civil e a ordem religiosa cuidavam dos "contra-anatureza" e "contra-a-lei", de modo que não se podia infringir a ordem das coisas e dos seres. 
Considerando essa "aliança legítima", os discursos dos séculos XVIII e XIX provocaram duas modificações. A primeira diz respeito à monogamia heterossexual. Não se fala dela mais com tanta frequência, embora continue sendo a regra interna das práticas e dos prazeres. $\mathrm{O}$ casal legítimo passa a ter direito à discrição. A segunda modificação é que se passa a interrogar a sexualidade das crianças, dos loucos e dos criminosos; "é o prazer dos que não amam o outro sexo, os devaneios, as obsessões, as pequenas manias ou as grandes raivas" (FOUCAULT, 1988, p. 46). Essas sexualidades não serão menos condenadas. A lei da aliança e a ordem dos desejos serviram, no Ocidente, como sistemas de regras que regeram o sexo. Não se podia infringir a legislação e a moral do casamento nem causar danos à regularidade do funcionamento natural, sob pena de sanção.

Mas eis que começa a surgir uma "gentalha diferente", apesar de possuirem parentescos com os antigos libertinos:

Do final do século XVIII até o nosso, eles correm através dos interstícios da sociedade perseguidos pelas leis, mas nem sempre, encerrados freqüentemente nas prisões, talvez doentes, mas vitimas escandalosas e perigosas presas de um estranho mal que traz também o nome de "vício" e, às vezes de "delito". Crianças demasiado espertas, meninas precoces, colegiais ambíguos, serviçais e educadores duvidosos, maridos cruéis ou maníacos, colecionadores solitários, transeuntes 
com estranhos impulsos: eles povoam os conselhos de disciplina, as casas de correção, as colônias penitenciárias, os tribunais e asilos; levam aos médicos suas infâmias e aos juizes suas doenças. Incontável família dos perversos que se avizinha dos delinquentes e se aparenta com os loucos. No decorrer do século eles carregavam sucessivamente o estigma da 'loucura moral', da 'neurose genital', da 'aberração do sentido genésico', da 'degenerescência' ou do 'desequilibrio psíquico' (FOUCAULT, 1988, p. 47, grifos do autor).

Essas sexualidades periféricas serão alvo de diversas instâncias de controle e de diferentes mecanismos de vigilância. Hoje, essas identidades ainda são marcadas pelo crivo da inferioridade e, de diversos lugares, ressoam as vozes que querem marcá-las como imorais e ilícitas. Mesmo com as falas que, dia após dia, enfatizam a pluralidade, a nossa sociedade ainda não se desvencilhou de certos discursos tidos como naturais, dentre eles o da heteronormatividade compulsória. Graças a ela, a identidade homoafetiva ainda não pode ser vivida sem receios.

Acreditamos na literatura como uma possibilidade de encontro com outras identidades, como um caminho capaz de romper com estereótipos e proporcionar o respeito àqueles que possuem hábitos, práticas e desejos diferentes. Assim, o texto que passamos a analisar - e que se constitui como uma sugestão de narrativa a ser incluída no currículo escolar - pode proporcionar ao leitor um encontro com a diversidade. 


\section{Análise da narrativa $O$ gato que gostava de cenoura, de Rubem Alves}

O gato que gostava de cenoura, de Rubem Alves, inicia-se com uma estrutura arquetipica dos contos de fadas tradicionais: "Era uma vez um gatinho" (ALVES, 2009, p. 5). Essa introdução apresenta a personagem principal da narrativa: um gato. Trata-se de uma fábula, com espaço e tempo indeterminados, em que o hábito alimentar é responsável por marcar o binarismo normal x anormal, para se referir à diferença que é constitutiva da identidade de Gulliver. Diferença que, aos poucos, vai revelando ao leitor que a identidade daquele gato destoa daquela idealizada pelos pais. Em páginas posteriores, essa diferença é apresentada ao leitor como parte da identidade homoafetiva de Gulliver ${ }^{3}$.

Logo no início da história, temos a caracterização da espécie animal gato e percebemos a identidade sendo marcada através de determinadas representações sociais:

Gatos são animais nobres.

Felinos.

Primos dos tigres, dos leões, das onças. Velozes, silenciosos, macios, elegantes. Símbolo da magia - toda bruxa tem um gato, preferivelmente negro.

Símbolo daquilo que fascina e atrai. Um homem bonito, amado pelas mulheres,

3 A antítese normal x anormal, que vai se construindo no decorrer da narrativa, resulta na oposição entre heterossexualidade $x$ homoafetividade ao final da narrativa. 
é um 'gato'. Uma mulher bonita, amada pelos homens, é uma 'gata'.

Os gatos, como todos os felinos, são caçadores (ALVES, 2009, p. 5, grifos do autor).

O nosso personagem principal pertence a uma familia nobre, temida, e deveria ser um selvagem, considerando o grupo dos felinos ao qual ele pertence, mas, ao contrário do que se espera, ele é meigo, é diferente daquilo que é apresentado como característica identitária de seu grupo familiar. Há, aqui, uma oposição de identidades: gato x outro e a construção da alteridade: eu x outro. Essa classificação mostra "como as relações sociais são organizadas e divididas" (WOODWARD, 2000, p. 14), pois o sistema classificatório "aplica um princípio de diferença a uma população de uma forma tal que seja capaz de dividi-la (e a todas as suas características) em ao menos dois grupos opostos - nós/eles" (WOODWARD, 2000, p. 40).

Segundo Kathryn Woodward (2000), as identidades ganham sentido por meio da linguagem e também pelos sistemas simbólicos que as representam. A representação, simbolicamente, classifica o mundo, as pessoas e as relações. Para a autora (2000, p. 10), a construção da identidade "é tanto simbólica quanto social". Ambos os processos - o social e o simbólico - são necessários para a construção das identidades. Por meio deles, define-se quem é excluído e quem é incluído. Um grupo é socialmente excluído quando é marcado, simbolicamente, como inimigo ou como um tabu. Isso 
implica em perdas materiais e sociais, podendo gerar a violência física e/ou verbal, além dos efeitos emocionais ou sentimentais.

A identidade homoafetiva, por exemplo, é excluída, considerada menor em relação à heterossexual. Os homoafetivos nem sempre usufruem os mesmos direitos que os heterossexuais, muitas vezes não podem ocupar os mesmos espaços e os mesmos cargos profissionais. Percebemos que a identidade do que é ser gato é construída apenas com atributos positivos e superiores. O gato possui grau de parentesco com animais temidos pelos demais - os tigres, os leões e as onças -, que têm autoridade sobre aqueles considerados inferiores e, culturalmente, a nossa sociedade o utiliza para elogiar o homem e a mulher. Neste último aspecto, vale ressaltar que o homem chamado de gato é aquele bonito, "amado pelas mulheres" e a mulher denominada de gata é aquela que, além de bonita, é "amada pelos homens". Em ambos os casos, o amor e a atração sexual se dão pelo oposto, em uma relação heterossexual, não se evidenciando a possibilidade de o homem e a mulher serem "gatos" em uma relação homoafetiva.

Na citação anterior, vemos que é "natural" que os gatos sejam caçadores. É da natureza do grupo, de sua raça possuir essa identidade. Esta é marcada como natural, como se não estivesse sempre em processo de construção, em devir. A identidade é vista em uma perspectiva 
essencialista $^{4}$, fixa e imutável, biologicamente determinada. A identidade sexual, por exemplo, parece reivindicar uma base biológica para se afirmar. Não se considera a fluidez das identidades e o fato de que elas não estão presas às diferenças imutáveis que valem em todos os contextos e épocas.

Na narrativa, o hábito alimentar assinala a identidade de um grupo e serve como marcação da diferença:

Gatos caçam peixes, ratos e pássaros. Um peixinho bobo, na superficie do tanque,

um passarinho distraído, comendo quirera,

um ratinho molenga, passeando pela casa,

e era uma vez um peixinho, um passarinho e um ratinho... Viraram comida de um gato.

Assim são os gatos, caçadores carní$\operatorname{voros}^{5}$ (ALVES, 2009, p. 5).

4 Segundo Kathryn woodward (2000), há duas versões do essencialismo identitário. A primeira é aquela em que a identidade é mostrada como produto da história, ela é fundamentada na "verdade" da tradição. A segunda é aquela que apresenta a identidade como "natural" e fixa e tem a "verdade" enraizada na biologia.

5 Os verbos "caçar" e "comer" merecem, aqui, um parêntese, tendo em vista o caráter metafórico do texto. Esses verbos remetem à cadeia alimentar, ao hábito de comer o outro, movimento antropofágico entre os animais carnívoros que caçam para sobreviver, em que estão em jogo a força e o instinto animal. Elementos que são, inclusive, metafóricos entre os humanos, uma vez que esses verbos, antropologicamente, remetem ao hábito alimentar - podem também denotar a virilidade masculina - e, ao mesmo tempo, às práticas sexuais. Caçar, no meio GLS (Gays, Lésbicas e Simpatizantes), é uma gíria para quem está a procura do outro, de um parceiro, seja para namorar ou, simplesmente, satisfazer o desejo sexual. 
Percebemos, pela citação, as microrrelações de poder existentes em uma comunidade. É um poder que se instaura de cima para baixo. Um grupo tem o domínio sobre os outros, tornando-os submissos e sem o direito de se manifestar. Esses outros são sempre colocados em uma posição de inferioridade. Os adjetivos utilizados para qualificar as outras espécies indicam um grau menor de importância e, de certa forma, submissão. Certas identidades sucumbem diante daquelas consideradas superiores e dominadoras.

As identidades diferentes, que não correspondem ao modelo, que fogem às expectativas e às normas sociais, como pontua Woodward (2000), são vistas como "estranhas" ou "desviantes":

Eles - os gatos - desprezam os coelhos - animais do mesmo tamanho, só que nem são caçadores nem carnívoros. Coelhos comem cenouras. Os gatos odeiam cenouras. Para os gatos, quem come cenoura é ruim da cabeça. Os coelhos devem ser doidos... (ALVES, 2009, p. 5).

Ou seja, os coelhos - os diferentes - precisam ser tratados, curados, é o discurso médico do século XVIII, de que nos fala Foucault. Ser diferente, ter gostos diferentes é sinal de loucura, de anormalidade, e não se encaixar em modelos padronizados é ser alvo de atenção e cuidados. Vemos que há a representação positiva de uma identidade - ser gato - e uma 
representação negativa de outra identidade ser coelho:

A representação, compreendida como um processo cultural, estabelece identidades individuais e coletivas [...]. Os discursos e os sistemas de representação constroem os lugares a partir dos quais os indivíduos podem se posicionar e a partir dos quais podem falar (WOODWARD, 2000, p. 17).

Alguns grupos têm direito à fala e se autorrepresentam, outros são apenas representados, são objeto do discurso alheio e têm as suas identidades construídas nos discursos daqueles que podem dizê-lo. As representações heterossexuais e a violência que produzem subjugam a subjetividade homoafetiva. Os termos, as expressões e as piadas não representam apenas uma injúria, trata-se da construção de uma imagem social, delimitada pela sexualidade e pela estigmatização da homoafetividade.

A identidade, que é marcada pela diferença - algumas diferenças, geralmente, são consideradas mais importantes que outras, principalmente em alguns contextos e lugares -, é também relacional. Para existir, uma identidade depende de algo fora dela, de outra identidade, aquela que ela não é, mas que oferece as condições para a sua existência. Logo, a diferença é marcada pela exclusão. Se for gato, não pode ser coelho, prevalecendo sempre a relação de antítese. O hábito alimentar, o parentesco com 
outros animais, o fato de ser caçador e carnivoro, simbolicamente, relaciona a identidade do ser gato com as outras identidades. Para que a identidade heterossexual exista e os membros do grupo se reconheçam como tal, é necessário que a identidade homoafetiva esteja ali.

As oposições binárias, conforme Woodward (2000), são a maneira mais extrema de marcar a diferença e são essenciais para que se compreenda o processo de construção cultural das identidades. Seus termos costumam expressar oposições cristalizadas, estando um dos termos sempre em relação de superioridade; essas oposições são ligadas às relações de poder. Ao contrário dos outros gatos, Gulliver não gostava de caçar, nem comer peixes, ratos e pássaros. Ele era diferente. Gulliver contraria, portanto, as expectativas de seus pais, que lhe deram esse nome - "o nome de um gigante" (ALVES, 2009, p. 6) - por acreditarem que o filho seria um "gato enorme, forte, valente, caçador" (ALVES, 2009, p. 6), o que seria "normal" para a espécie dele.

Por meio desse nome - a linguagem nomeia e classifica -, percebemos a idealização dos pais em relação à identidade do filho. Gulliver contraria o "normal", o preestabelecido, sendo considerado pela sociedade e por seus pares um corpo que não pesa, não tem valor, pois transgride a norma, incomoda. Há uma desconstrução da identidade idealizada por seus pais e pela sua comunidade em relação ao que é ser gato, uma vez que Gulliver não atende àquilo que se espera de 
sua espécie: "Seus pais lhe traziam deliciosos ratinhos recém-nascidos, pardais saborosos, peixes cheirosos: tudo em vão. Ele quase vomitava" (ALVES, 2009, p. 6). De uma maneira ou de outra, há a tentativa e a insistência das instituições em modificar e moldar as identidades daqueles que fogem ao padrão instituido socialmente.

O comportamento estranho dos sujeitos está sempre sob o alvo dos olhares que o descobrem, o percebem, o investigam, fazendo com que ele seja confessado e disciplinado. Conforme Foucault (1988), a partir do século XVIII, os discursos sobre o sexo se aceleraram no campo de exercício do poder. Há uma incitação a falar de sexo cada vez mais. Com a evolução da pastoral católica e do sacramento da confissão, após o Concílio de Trento, o sexo

[...] não deve mais ser mencionado sem prudência; mas seus aspectos, suas correlações, seus efeitos devem ser seguidos até às mais finas ramificações: uma sombra num devaneio, uma imagem expulsa com demasiada lentidão, uma cumplicidade mal afastada entre a mecânica do corpo e a complacência do espírito: tudo deve ser dito [...] o sexo é açambarcado e como que encurralado por um discurso que pretende não lhe permitir obscuridade nem sossego (FOUCAULT, 1988, p. 25-26).

Todos os comportamentos e atitudes "estranhas" devem ser considerados. Os pais de 
Gulliver, então, resolvem levá-lo ao médico. A diferença é vista como uma patologia. A confissão também era necessária para as intervenções médicas, para a elaboração do diagnóstico eficaz na busca pela cura. Os médicos não possuíam uma explicação para a falta de apetite do gatinho, pediam exames, mas descobriam que não havia nada de errado com o corpo de Gulliver.

Os pais dele nem imaginavam que ele comia escondido a "comida proibida", pois ele comia cenoura, como os coelhos. O que é proibido só pode ser feito às escondidas, por isso Gulliver não contava a ninguém o que comia. A proibição também serve para distinguir as identidades que são inclusas em um sistema ou grupo daquelas que são excluídas. Se alguém descobrisse do que Gulliver se alimentava, "Todos ririam dele, um gato que tem o gosto dos coelhos..." (ALVES, 2009, p. 8), ele não poderia assumir a sua identidade, caso contrário, seria ridicularizado.

Por conta desse seu gosto diferente, Gulliver estava sempre sozinho, não saía com os outros gatos, pois os outros saíam para caçar e comer ratos e Gulliver, quando tentava fazer o mesmo, acabava vomitando. Ele tenta dissimular a sua identidade. O diferente, por medo da repressão, da violência e da rejeição, até tenta seguir o modelo padrão, ajustar-se às regras culturais e sociais. Gulliver "Preferia a solidão. Ninguém o entenderia" (ALVES, 2009 , p. 8). Ele não tinha amigos porque era diferente, e não ter amigos fazia parte de sua 
identidade estigmatizada social e culturalmente pelo outro.

O medo da não aceitação, da gozação, da injúria e da agressão, constrói a identidade e a personalidade daqueles que são considerados diferentes. Gulliver não vivia sozinho porque gostava, mas porque precisava. A identidade que o moldava era determinada pela posição que ele ocupava. O medo de ser descoberto fazia com que Gulliver se mantivesse afastado dos outros gatos. Como pontua Didier Eribon (2008), as subjetividades "homossexuais" também são construídas a partir da procura dos meios de fuga da injúria e da violência, por isso eles desenvolvem diferentes tipos de comportamento para serem utilizados de acordo com as pessoas com quem convivem e os ambientes que frequentam.

A mãe gato, preocupada com o filho, afirma que tem "medo de que [ele] esteja fazendo alguma coisa errada" (ALVES, 2009, p. 8). A família também é uma instituição vigilante, que pretende disciplinarizar os corpos, os hábitos e os desejos, por isso, a mãe sugere que o pai siga Gulliver e assim ele faz. Não ser igual aos de sua espécie faz com que a mãe de Gulliver o imagine fazendo "coisa errada". O considerado "correto" é aquilo que seu grupo tem o hábito de fazer, comer e realizar.

Gulliver, chegando ao sítio de seu Joaquim, onde havia canteiros com diversos tipos de hortaliças, dentre os quais canteiros de cenoura, se certifica de que está sozinho, olha para um lado e para o outro e começa a 
"fazer a coisa proibida, horrivel, desprezivel para um gato. Começou a comer cenouras" (ALVES, 2009, p. 8). O gato se certifica de que ninguém estava vendo seu ato "pecaminoso" e só aí assume sua identidade. Ali, no meio das hortaliças, Gulliver pode ser ele mesmo, sem fingimentos, pois o "armário" também é "um espaço de liberdade e um meio - o único - de resistir e de não se submeter às injunções normativas" (ERIBON, 2008, p. 67).

Esses canteiros não deixam de, metaforicamente, representar as diversas possibilidades de relações afetivas e sexuais. Não há uma única maneira de se viver - afetiva e sexualmente -, embora a heteronormatividade compulsória assim faça parecer. São diversas as identidades e muitas ainda têm que viver à margem, na fronteira do lícito e do ilícito, ou se manifestar somente à noite, quando os sujeitos de "moral e bons costumes" estão em casa dormindo.

Esse acontecimento presenciado pelo pai provoca nele uma grande decepção, pois desejava um filho que se parecesse com um tigre. Ao voltar para casa, o pai e a sua mulher, a mãe gata, "choraram amargamente" (ALVES, 2009, p. 8). Por não materializar a norma, Gulliver é motivo de tristeza para os pais. Como ele, muitos sujeitos, quando resolvem assumir a sua identidade homoafetiva, são vistos como motivo de sofrimento e vergonha para a família, às vezes são expulsos de casa e rejeitados pelos familiares. Foi o que aconteceu, e se complicou, quando um colega de escola também o viu 
comendo cenoura. "Gulliver tornou-se objeto de zombaria" (ALVES, 2009, p. 10) e os amigos começaram a chamá-lo de coelho.

$\mathrm{O}$ ato de linguagem, atravessado constantemente pelas relações sociais, nomeia a diferença; é por meio dela e através dela que ocorre a "dominação simbólica" (ERIBON, 2008, p. 95), ou seja, a definição das percepções que se tem do mundo e das representações socialmente legítimas. A injúria e o insulto fazem o outro, o diferente, o homoafetivo, ser apontado e ridicularizado, pois a linguagem o nomeia como estranho, como objeto e como abjeto, a partir do olhar do outro:

Descubro que sou alguém de quem se pode dizer isto ou aquilo, alguém que é objeto dos olhares, dos discursos e que é estigmatizado por esses olhares e esses discursos. A 'nomeação' produz uma conscientização de si mesmo como um 'outro' que os outros transformam em 'objeto' (ERIBON, 2008, p. 28).

A injúria produz o efeito da vergonha, do menosprezo e da solidão, institui e perpetua o corte entre os "normais" e os "estigmatizados" e esse corte se enraíza nos sujeitos. A agressão verbal representa uma ameaça constante à vida social daqueles que não têm a sua identidade aceita: "Para o homossexual 'descoberto', a injúria não seria mais apenas um horizonte, uma potencialidade cuja ameaça está sempre presente no espírito, mas um inferno no cotidiano" (ERIBON, 2008, p. 67). O homoafetivo vive em 
um mundo de injúrias que preexistem àquele que as proferem e àqueles que as recebem.

Por ser a linguagem histórica, política e social, é necessária uma análise das estruturas antropológicas que constituem a nossa sociedade a fim de se compreender como a injúria constitui a identidade homoafetiva e de que forma pode ser combatida. Não teríamos resolvido o problema do preconceito e da discriminação, tendo em vista que, como pontua Eribon (2008, p. 101), a injúria representa apenas a ponta, o "traço verbal limite da violência simbólica", que designa a sexualidade segundo hierarquizações e exclusões que sempre colocam a homoafetividade em um grau de inferioridade. Aqueles que não possuem os mesmos hábitos não são aceitos e ficam à margem.

A injúria acaba por determinar a relação daquele que a recebe com o mundo, produzindo no sujeito um sentimento de insegurança, de angústia - e nas crianças e adolescentes, produz até o pânico. Vivem a angústia constante de serem descobertos, por isso, alguns sujeitos tentam viver na norma para fugir do controle e da vigilância. As instituições sociais têm contribuido para que a dissimulação da identidade homoafetiva não tenha fim, uma vez que aprovam tal prática, contribuindo para perpetuá-la, em vez de se posicionarem contra a ordem social que determina a heterossexualidade compulsória e estigmatiza outras identidades.

No texto analisado, os pais de Gulliver, sofrendo junto com o filho, aprenderam, com livros de psicologia, que o medo do sofrimento 
constitui-se como uma ferramenta para que os bichos mudem seus hábitos: "Até bichos ferozes como leões e ursos, por medo, aprenderam a dançar nos circos" (ALVES, 2009, p. 10). Eles esperam que, com o sofrimento, o protagonista mude os seus hábitos, discipline seu corpo, seus desejos e suas práticas. Ele não é aceito pelo sistema, pela instituição familiar e pelos amigos justamente porque é diferente. Então, os pais dele mandam-no conversar com o gato-padre, D. João Severo, cujo nome sugere severidade, nomeia a sua identidade e função.

Segundo Foucault (1988), a nossa civilização é a única a praticar uma scientia sexualis. A sociedade desenvolveu procedimentos que se ordenam em uma forma de poder-saber para se dizer a verdade do sexo. A confissão é um dispositivo da ciência do sexo e, desde a Idade Média, constitui-se como um dos rituais mais importantes como produção de verdade nas sociedades ocidentais, tais como:

[...] a regulamentação do sacramento da penitência pelo Concílio de Latrão em 1215; o desenvolvimento das técnicas de confissão que vêm em seguida; o recuo, na justiça criminal, dos processos acusatórios; o desenvolvimento das provações de culpa (juramentos, duelos, julgamentos de Deus); e o desenvolvimento dos métodos de interrogatório e de inquérito; a importância cada vez maior ganha pela administração real na inculpação das infrações - e isso às expensas 
dos processos de transação privada a instauração dos tribunais de Inquisição, tudo isso contribui para dar à confissão um papel central na ordem dos poderes civis e religiosos (FOUCAULT, 1988, p. 67).

Somos uma sociedade que confessa. A confissão, pouco a pouco, desde o século XVI, deixou de ser um ritual exclusivo da prática da penitência. Todas as instâncias e relações passam a se utilizar da confissão (ajustou-se a técnica da confissão ao discurso científico): a justiça, a medicina, a pedagogia, as relações familiares e amorosas, no cotidiano ou nas situações solenes. Entre delinquentes e peritos, doentes e médicos, alunos e pedagogos, crianças e pais. Os crimes, os pecados, os desejos, os pensamentos, os sonhos, tudo deve ser confessado, em particular ou em público, aos pais, aos educadores, aos médicos, a quem se ama ou a si mesmo, o prazer e/ou a dor, que não se pode confiar ao outro. "Quando a confissão não é espontânea ou imposta por algum imperativo interior, é extorquida; desencavam-na na alma ou arrancam-na ao corpo" (FOUCAULT, 1988 , p. 68), sendo aquele que a escuta dono não somente do perdão ou da condenação, mas também o dono da verdade. Portanto, além de exigir a confissão e decidir o que fazer após a mesma ser feita, o ouvinte deve elaborar um discurso de verdade sobre o que ouviu.

Por ser imposta por diferentes pontos, a confissão incorporou-se a nós, e o sujeito já não a percebe como estratégia de um poder 
que constrange. A verdade não é livre por natureza, a sua produção está ligada às relações de poder. A identidade do indivíduo foi ora autenticada pela relação que se estabelecia com o outro - a família, por exemplo - ora pelo discurso de verdade que o indivíduo era capaz de dizer sobre si mesmo. O sexo ainda é tema privilegiado na confissão, e por meio dela, verdade e sexo ligam-se:

O exame médico, a investigação psiquiátrica, o relatório pedagógico e os controles familiares podem, muito bem, ter como objetivo global aparente dizer não a todas as sexualidades errantes ou improdutivas mas, na realidade, funcionam como mecanismos de dupla incitação: prazer e poder. Prazer em exercer um poder que questiona, fiscaliza, espreita, espia, investiga, apalpa, revela; e, por outro lado, prazer que se abrasa por ter que escapar a esse poder, fugir-lhe, enganá-lo ou travesti-lo. Poder que se deixa invadir pelo prazer que persegue e, diante dele, poder que se afirma no prazer de mostrar-se, de escandalizar ou de resistir. Captação e sedução; confronto e reforço reciprocos: pais e filhos, adulto e adolescente, educador e alunos, médico e doente, e o psiquiatra com sua histérica e seus perversos, não cessaram de desempenhar esse papel desde o século XIX (FOUCAULT, 1988, p. 52-53).

Dessa maneira, a relação entre o poder, o saber e o prazer estão intimamente relacionados na narrativa. Por exemplo, o poder representado pelas instituições familiar, religiosa e 
médica, pelos colegas da escola; um saber que se dá quando os pais de Gulliver e os colegas da escola descobrem o seu gosto por cenouras e quando ele tem que confessar ao médico, ao padre e ao psicanalista o seu hábito alimentar diferente; e um prazer por parte de Gulliver, quando tenta escapar da vigilância ou quando pode assumir a sua identidade.

O discurso religioso funciona como repressão à atitude de Gulliver. Ele tem de confessar ao padre os seus pecados. O sujeito deve confessar as atitudes contrárias à lei e transformar todo o seu desejo em discurso. Um dos efeitos que pretendia a pastoral cristã era a "reconversão espiritual", o retorno a Deus, "efeito físico de dores bem-aventuradas por sentir no seu corpo as ferroadas da tentação e o amor que lhe resiste" (FOUCAULT, 1988, p. 29).

O gato-padre, com um pelo lustroso e pretíssimo, com olhos verdes e longo rabo encurvado - a descrição do padre exala poder e autoridade - abriu um livro sagrado e

[...] disse que Deus, o Gato Supremo, determinara que rato, passarinho e peixe são os manjares dos deuses. Assim, por determinação do Deus-Gato, gatos têm de comer ratos, passarinhos e peixes. Comer cenouras é pecado mortal. É contra a natureza. Ai lhe falou sobre o inferno, um lugar terrivel para onde vão todos os gatos que comem cenouras (ALVES, 2009, p. 10). 
O gato-padre disse que o inferno seria o destino de Gulliver se ele não parasse de comer cenouras e, como penitência, ordenou que comesse dois ratos. Ele tentou, pois era obediente, mas acabou vomitando. Observamos a penitência que lhe é dada, para fazer aquilo que era considerado "correto" e desistir de realizar os seus desejos. O discurso religioso inculca nos sujeitos que a homoafetividade é pecado, que a "multiplicação" - ordenada por Deus - sofre a ameaça de práticas não heterossexuais.

Deve-se se dizer a si mesmo e a outrem sobre os prazeres, sensações e pensamentos que envolvam o sexo. Colocá-lo em discurso não é simplesmente condená-lo ou tolerá-lo, mas inseri-lo em "sistemas de utilidade", regulando-o para o bem de todos, fazendo com que funcione "segundo um padrão ótimo" (FOUCAULT, 1988, p. 31). O discurso estabelecido diz que o que Gulliver faz é pecado e o certo seria ter outra postura, mais natural, "correta", comer rato, passarinho e peixe. Não mudar a sua postura e seus hábitos poderia fazer de Gulliver um merecedor do inferno.

Assim, na narrativa analisada, estão presentes o dispositivo da vigilância (instituição familiar), a técnica da confissão (feita ao médico, ao padre e ao psicanalista), a imposição de discursos e a correção (realizados pelo padre). Como nos diz Foucault (1988), o ritual da confissão envolve um discurso em que o sujeito que confessa corresponde ao sujeito do enunciado, desencadeando uma relação de poder, uma vez 
que, para se confessar, exige-se a presença mesmo virtual - de um parceiro, que é mais do que interlocutor. Este se constitui como a instância que solicita, impõe e avalia a confissão, intervindo com o julgamento, a punição, o perdão, o consolo e/ou a reconciliação. Tratase de um ritual que inocenta, purifica, livra de faltas, liberta e salva o confessor.

Ressaltamos que, nesse ritual, a dominação não está em quem fala, mas com aquele que escuta e cala; não está com quem sabe e responde, mas com quem interroga, assim como a verdade produzirá efeito não naquele que ouve o discurso, mas naquele de quem ele é extorquido. Dessa forma, Gulliver, em suas relações de confissão ao médico, ao padre e ao psicanalista, é sempre o dominado, aquele que fala, que sabe e responde sobre o seu delito. Seus pais não desistiram de encontrar a cura para o problema e o levaram ao psicanalista, Dr. Gatan que, após vários anos de análise, deu uma explicação que não resolveu o problema, pois o gato continuou do mesmo jeito.

$\mathrm{Na}$ escola, um professor que percebeu o sofrimento, "sempre sozinho, sem amigos, objeto da zombaria dos colegas" (ALVES, 2009, p. 12) - pelo diferente vive sob o crivo do sentimento de culpa e de inferioridade, que é inscrito em sua consciência individual - estabelece um diálogo com ele; utiliza-se da genética para lhe explicar sobre as diferenças e como o destino dos seres já está determinado pelo DNA. A cor dos olhos, do pelo, se seria gato ou gata e que ninguém é capaz de desfazer o que a natureza fez: 
- Por vezes, o disquete DNA não funciona da forma esperada. E, quando o bichinho nasce, nasce um pouquinho diferente. Alguns, chamados daltônicos, não vêem as cores do jeito como a maioria vê. Outros, chamados canhotos, funcionam melhor com a mão esquerda que com a direita. Eles têm de tocar violão ao contrário - e deu uma risada. - $\mathrm{Pa}-$ rece que esse é o caso com aqueles que têm uma dieta de amor diferente daquela reconhecida como padrão. O padrão é gato comer rato. Mas você gosta é de cenoura (ALVES, 2009, p. 14).

Existem muitas diferenças entre as pessoas, algumas são mais toleradas - talvez porque mais facilmente dissimuladas -, enquanto outras são, constantemente, alvo de apontamentos e rejeições. Gulliver rompeu com um padrão já estabelecido, seu hábito alimentar não corresponde ao dos outros membros de seu grupo. O discurso do professor contrapõese aos discursos médico e religioso; ele mostra que a diferença é possível:

- Os chamados heterossexuais amam o diferente: o corpo dos homens se comove ao ver um corpo de mulher; o corpo das mulheres se comove ao ver o corpo de um homem. Mas o corpo dos homossexuais, quem sabe se por obra do DNA, se comove ao ver um corpo igual ao seu (ALVES, 2009, p. 16).

O professor explicita que o desejo pode ser pelo oposto ou pelo igual; existem ambas 
as formas de desejo e elas são válidas. Tantas diferenças - de etnia, de gênero, de sexo e de cultura - existem em nossas salas de aula e há muito para dialogar, romper e avançar sobre elas. É o que ocorre com Gulliver, o qual ficou feliz por perceber que o seu professor o compreendia e não pretendia "consertá-lo" ou torná-lo igual aos outros: “'Meu Deus!” - ele gritou em silêncio. "Eu tenho um amigo! Eu tenho um amigo!"” (ALVES, 2009, p. 18). Sua única preocupação era não precisar ter vergonha, não queria ser igual aos outros, mas o que era: "um gato que gostava de cenouras!", queria que a sua identidade fosse aceita e respeitada, como muitos alunos - sujeitos desejam.

Como podemos perceber, os discursos religiosos e médicos oferecem possibilidades de cura, de salvação, como se a homoafetividade fosse uma patologia, um pecado, e a sua identidade e a subjetividade, consideradas segundo o padrão tido por legítimo. Nesse caso, o discurso pedagógico representa a possibilidade de compreensão, o ambiente escolar pode propiciar o diálogo das diferenças e o professor pode mediar esse processo que pretende romper com o preconceito e a indiferença em relação ao outro.

As convenções sociais determinam aquilo que é permitido e o que não é, a quem é permitido e em que contexto:

Só os períodos de crise social, cultural, ou pelo menos a irrupção de mobilizações politicas ou culturais, podem 
permitir um questionamento dessa ordem simbólica das representações e da linguagem cuja força principal é apresentar-se como se resultasse das evidências de uma ordem natural, imutável, e sobre a qual não se interroga ou sobre a qual falsamente se interroga para melhor reafirmá-la em seu arbitrário, apresentando-a como se tivesse sempre existido (ERIBON, 2008, p. 95-96).

Dentre os meios de representação está o currículo, que pode ser "um território contestado" (SILVA, 2009), na medida em que se torne capaz de desconstruir - e reconstruir - as representações de gênero, sexo, etnia e classe, dentre outras. A escola e o professor podem desempenhar um papel mais ativo e reflexivo em relação às relações de poder que o currículo estabelece. A leitura da narrativa infantil que analisamos é uma maneira de instaurar, nas salas de aula, o discurso, o conhecimento e o reconhecimento da diferença e da diversidade sexual, de oferecer voz a outras identidades. Então, por que não dar lugar ao livro O gato que gostava de cenoura em nossas bibliotecas? Por que não possibilitar, aos nossos alunos e alunas, o processo efetivo de humanização por meio da literatura? Por que não trabalhar com a leitura de textos que possibilitem uma efetiva e profícua discussão acerca das diferenças identitárias, constitutivas de nossas subjetividades? 


\section{Considerações finais}

Como procuramos demonstrar, o texto literário permite ao leitor o contato com a alteridade e, por conseguinte, com os valores sociais, culturais e históricos de uma sociedade que podem ser questionados ou não na tessitura do texto. Abordar determinadas temáticas, como, por exemplo, a diversidade sexual e de gênero, pode ajudar a desconstruir certos preconceitos arraigados em vários discursos de nossa sociedade balizada por uma matriz heterossexual, que inclui as identidades de gênero e sexuais que não se encaixam nas normas preestabelecidas.

A representação que o texto literário faz do outro pode auxiliar na desconstrução ou perpetuação do preconceito e das definições já enraizadas na sociedade. A narrativa infanto-juvenil que analisamos, por exemplo, permite-nos questionar padrões vigentes de modelos fixos de identidade, abrindo espaço para que o leitor, de forma crítica, perceba as ideologias e o envolvimento do social, do histórico e do cultural na elaboração do sentido e dos valores criados e transmitidos pelos personagens do texto.

Para que o leitor se posicione criticamente diante do que lê, não basta a simples leitura/ decodificação das palavras, é necessário que ele se aproprie da leitura e faça dela instrumento de (trans)formação. Assim, poderemos falar em uma efetiva formação de leitor crítico que, para ser efetivada, a nosso ver, requer a participação do professor como mediador de questões ainda 
consideradas dificeis de serem abordadas, mesmo constando em documentos oficiais, como os Parâmetros Curriculares Nacionais (PCN).

Se os PCN tratam da temática da diversidade sexual como tema transversal, se o texto literário permite uma abordagem interdisciplinar, acreditamos que é possivel, sim, a formação do leitor crítico para a diversidade, desde que a ele sejam dados os meios de dialogar com o texto literário e com esse outro representado no discurso literário. No entanto, as obras que tratam dessa temática não têm chegado à escola e às salas de aula, de modo que não têm sido trabalhadas nas escolas, ou por falta de preparo dos docentes, ou porque essas questões são vistas com "maus olhos" e, portanto, como desnecessárias à formação dos alunos.

Quando o professor discute com seus alunos uma narrativa literária que aborda questões não somente heterossexuais, abre espaço para a diversidade, para o diálogo com outras identidades, permitindo que os sujeitos leitores conheçam, questionem e reflitam a respeito do outro. Os discursos constituídos historicamente subsidiam a negação de determinadas identidades. É claro que não podemos negar, como pontuam os PCN para o Ensino Fundamental, que cada sociedade possui regras que regem o comportamento sexual, mas isso não deve significar a supervalorização de uma identidade em detrimento de outras, uma vez que vivemos em uma sociedade plural, e apontar uma ou outra identidade como "verdadeira" e "correta" faz com que diversas identidades sejam excluídas e reprimidas. 
Por meio do texto literário, é possível que se trabalhe com as crianças as temáticas apresentadas pelos PCN, dentre elas, a orientação sexual. A leitura do texto literário permite que o leitor desvele regras impostas por meio de discursos já arraigados na sociedade. O texto literário possibilita a formação de um leitor, capaz de questionar, compartilhar e experienciar a identidade do outro representado no texto. Por isso, a literatura infantil e juvenil, que se abre a revelar o outro, em suas diferentes identidades, possibilita, às crianças e aos jovens, perceber e respeitar aqueles que são diferentes.

Portanto, acreditamos que se trata de uma temática merecedora do devido respaldo dos professores em sala de aula, uma vez que eles são os mediadores, na maioria das vezes, entre o texto e o leitor, cabendo-lhes, desse modo, intermediar as reflexões e suscitar questionamentos que provoquem nos nossos jovens alunos, leitores em processo de formação, uma ruptura com alguns dos paradigmas tradicionais de nossa sociedade, como, por exemplo, a matriz heterossexual. A literatura, como forma de conhecimento, é um meio de se adquirir "noções, emoções, sugestões, inculcamentos" (CANDIDO, 2004 , p. 179), também um veículo para contestar "verdades" e discursos proferidos por quem detém o poder. Mesmo enfatizada como capaz de humanizar, não deveriamos considerar apenas o seu conteúdo e os valores éticos, pois age de diferentes modos na vida do ser humano, possibilitando-lhe uma maior compreensão do outro e do próprio meio social, cultural e histórico. 


\section{REFERÊNCIAS}

ALVES, Rubem. 0 gato que gostava de cenoura. 3. ed. São Paulo: Loyola, 2009.

BRASIL. Parâmetros Curriculares Nacionais: apresentação dos temas transversais. Secretaria de Educação Fundamental. Brasília, DF: MEC: SEF, 1997.

Parâmetros Curriculares Nacionais: orientação sexual. Secretaria de Educação Fundamental. Brasilia, DF: MEC: SEF, 1997.

CANDIDO, Antonio. O direito à literatura. In: . Vários escritos. São Paulo: Duas Cidades, 2004.

ERIBON, Didier. Um mundo de injúrias. In: Reflexões sobre a questão gay. Tradução de Procópio Abreu. Rio de Janeiro: Companhia de Freud, 2008.

FOUCAULT, Michel. História da sexualidade I: a vontade de saber. Tradução de Maria Thereza da Costa Albuquerque; J. Guilhon Albuquerque. Rio de Janeiro: Graal, 1988.

SILVA, Tomaz Tadeu da. Currículo e identidade social: territórios contestados. In: SILVA, Tomaz Tadeu da (Org.). Alienigenas na sala de aula: uma introdução aos estudos culturais em educação. Rio de Janeiro: Vozes, 2009. 
WOODWARD, Kathryn. Identidade e diferença: uma introdução teórica e conceitual. In: SILVA, Tomaz Tadeu da (Org.). Identidade e diferença: a perspectiva dos estudos culturais. Rio de Janeiro: Vozes, 2000. 